\title{
ESTIMATIVA DA EROSÃO DO SOLO E AVALIAÇÃO DO SEU IMPACTO NA MICROBACIA DO CEVEIRO (PIRACICABA, SP), ATRAVÉS DO ÍNDICE DE TEMPO DE VIDA
}

\section{MARA DE ANDRADE MARINHo WEILL}

Engenheiro Agrônomo

Orientador: Prof. Dr. GERD SPAROVEK

Tese apresentada à Escola Superior de Agricultura "Luiz de Queiroz", Universidade de São Paulo, para obtenção do título de Doutor em Agronomia, Área de Concentração: Solos e Nutrição de Plantas.

\author{
P I R A C I C A B A \\ Estado de São Paulo - Brasil \\ Maio - 1999
}




\section{Dados Internacionais de Catalogação na Publicação (CIP) DIVISÃo DE BIBLIOTECA E DOCUMENTAÇÃO - Campus "Luiz de Queiroz"/USP}

Weill, Mara de Andrade Marinho

Estimativa da erosão do solo e avaliação do seu impacto na microbacia do Ceveiro (Piracicaba, SP), através do indice de tempo de vida / Mara de Andrade Marinho Weill. - Piracicaba, 1999.

100 p. : il.

Tese (doutorado) - Escola Superior de Agricultura Luiz de Queiroz, 1999. Bibliografia.

1. Agricultura sustentável 2. Degradação ambiental 3. Degradação do solo 4. Erosão 5. Impacto ambiental 6. Microbacia do córrego do Ceveiro 7. Planejamento 8. SIG 9. Uso da terra I. Titulo

CDD 551.483

Mermitida a copta total o o parcial deste documento desde que citada a fonte 0 Autor? 
Em memória de meus pais,

Que me brindaram com todo

Amor que um filho pode desejar.

Aos meus queridos,

Paulo, Gaston e Victor

Meus amores de hoje e de sempre. 


\section{AGRADECIMENTOS}

À Escola Superior de Agricultura "Luiz de Queiroz", em especial à Coordenação do Curso de Pós-Graduação e ao Departamento de Solos e Nutrição de Plantas, pelo acompanhamento acadêmico e provimento de recursos para desenvolvimento e divulgação deste trabalho;

Ao Conselho Nacional de Pesquisa, pelo provimento de bolsa de estudos e outros recursos financeiros para desenvolvimento e divulgação;

À Fundação de Amparo à Pesquisa do Estado de São Paulo, pelo financiamento do projeto de pesquisa;

Ao Professor Dr. Gerd Sparovek, pela orientação no desenvolvimento deste trabalho;

Aos Colegas da Pós-Graduação, em especial do grupo do Projeto Ceveiro, pela convivência agradável, companheirismo, ajuda mútua e constante troca de idéias;

Ao Dr. Flávio Bussmeier Arruda, pela amizade e apoio durante o desenvolvimento de meu programa de treinamento;

Aos funcionários da ESALQ, que com o seu trabalho e dedicação, contribuíram de muitas maneiras para a realização deste trabalho de pesquisa;

A todos aqueles que, direta ou indiretamente, participaram e contribuíram para a realização deste trabalho. 


\section{SUMÁRIO}

Página

LISTA DE FIGURAS..........................................................................................vii

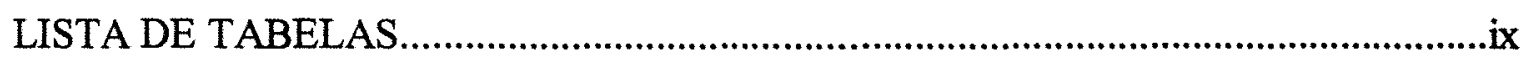

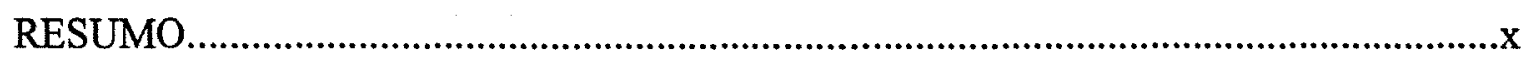

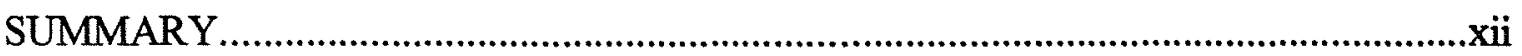

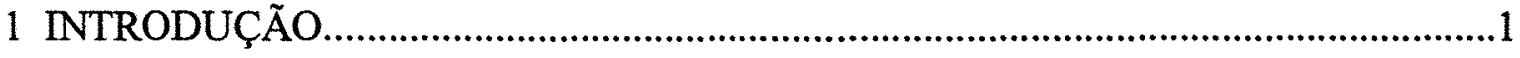

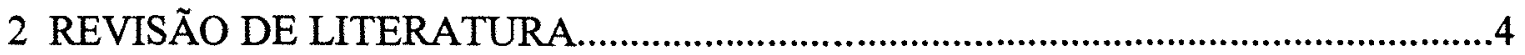

2.1 Sustentabilidade e uso sustentável em agricultura..........................................................4

2.2 Planejamento do uso das terras e planejamento ambiental........................................6

2.2.1 Importância do solo e da água nos agroecossistemas........................................8

2.3 Erosão acelerada do solo e degradação de terras............................................................10

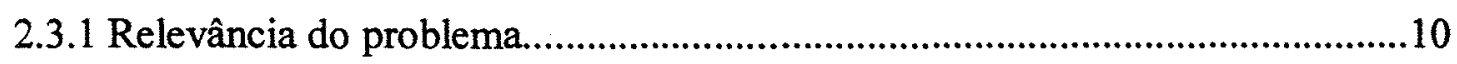

2.3.2 Definição e tipos de erosão acelerada...................................................................11

2.3.3 Impactos diretos e indiretos da erosão acelerada..............................................13

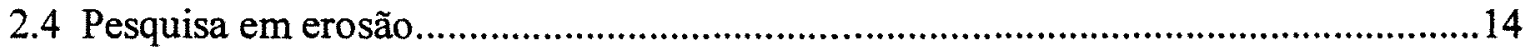

2.4.1 Estimativa da perda de solo ou modelagem da erosão.......................................14

2.4.2 Conceito de tolerância de perda de solo...........................................................18

2.4.3 Relação entre erosão e produção.....................................................................22

2.5 Ferramentas tecnológicas para um planejamento dinâmico......................................24

2.5.1 A tecnologia de Sistemas de Informação Geográfica (SIG)..............................24

2.5.2 O método geoestatístico de análise da variabilidade espacial

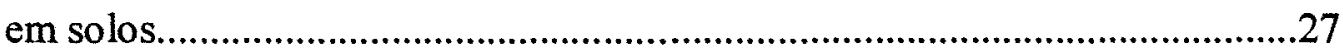

2.6 Considerações sobre a proposição da pesquisa......................................................30

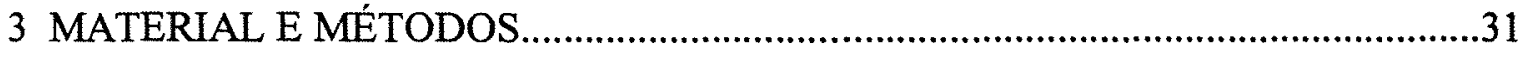

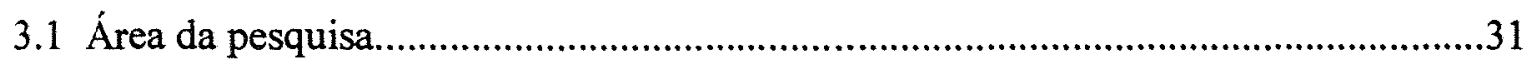

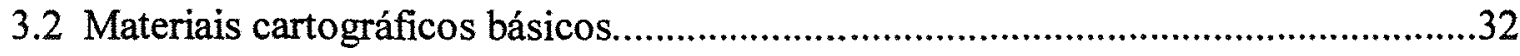

3.3 Implantação do banco de dados espaciais....................................................................33

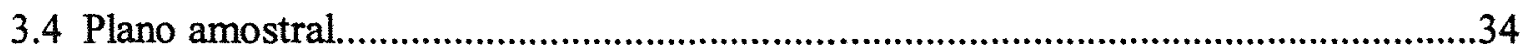


3.4.1 Georeferenciamento dos locais de amostragem de solos. .35

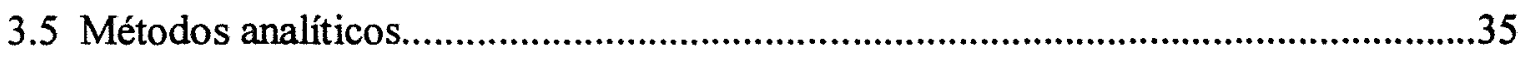

3.6 Estimativa das perdas de solo: ajuste dos fatores do modelo USLE............................38

3.6.1 Fator R ou fator erosividade da precipitação e da enxurrada..................................38

3.6.2 Fator K ou fator erodibilidade do solo...................................................................39

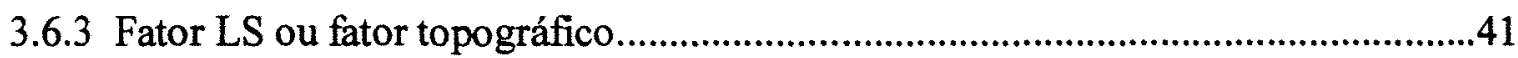

3.6.3.1 Áreas de não cana-de-açúcar do Ceveiro................................................41

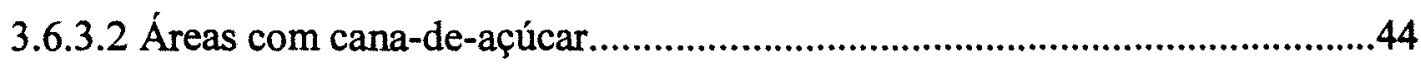

3.6.4 Fator $\mathrm{C}$ ou fator de cobertura e manejo da cultura.....................................................47

3.6.5 Fator $\mathrm{P}$ ou fator prática de controle da erosão............................................................47

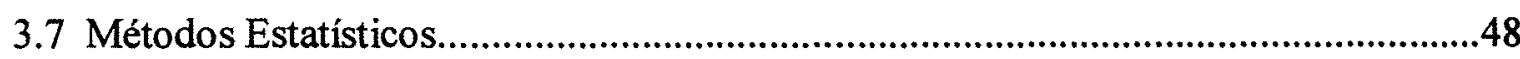

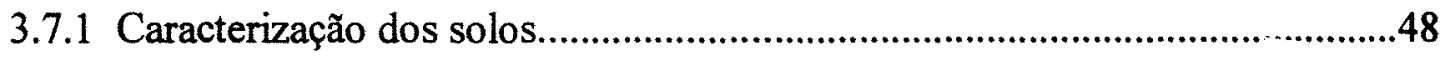

3.7.2 Obtenção de parâmetros por interpolação.........................................................48

3.7.3 Estudo de sensibilidade dos fatores do modelo USLE.................................49

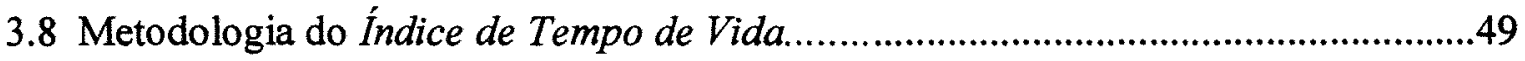

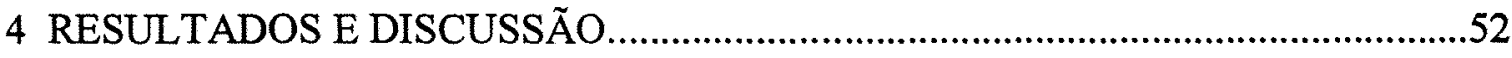

4.1 A bacia hidrográfica do Ribeirão do Ceveiro (BHC)................................................52

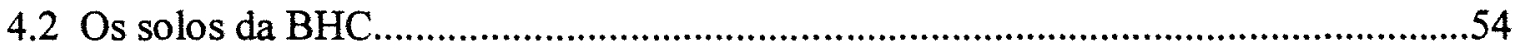

4.3 Modelagem da erosão do solo na bacia hidrográfica do Ribeirão do Ceveiro...........60

4.3.1 Caracterização dos fatores do modelo USLE...............................................60

4.3.2 Perda de solo na bacia hidrográfica do Ribeirão do Ceveiro.............................66

4.3.3 Influência dos fatores da USLE, nas taxas estimadas de perda de

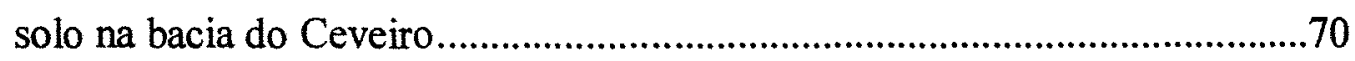

4.3.4 Simulação do efeito alternado dos fatores LS e K..............................................73

4.4 Interpretação dos resultados da modelagem de perda de solo....................................76

4.4.1 Interpretação baseada unicamente em critérios de tolerância de 
de perda de solo

.76

4.4.2 Interpretação baseada na metodologia do índice de tempo de vida .78

4.4.2.1 Conservação e Tempo Zero nas áreas de não cana-de-açúcar (NC)

4.4.2.2 Conservação e Tempo Zero nas áreas de cana-de-açúcar

4.4.2.3 Conservação e Tempo Zero na bacia do Ceveiro como um todo. .81

4.4 Tempo de vida nas áreas de controle da bacia do Ceveiro .82

4.5 Considerações finais. .89

5 CONCLUSÕES. .91

REFERÊNCIAS BIBLIOGRÁFICAS. .93 


\section{LISTA DE FIGURAS}

Página

1 Bacia hidrográfica do Ribeirão do Ceveiro, município de

Piracicaba (SP): limites, áreas urbanas e hidrografia.

2 Locais de amostragem dos solos da bacia hidrográfica do

Ribeirão do Ceveiro.

3 Detalhe da malha regular de amostragem de solos, ou grid, da bacia hidrográfica do Ribeirão do Ceveiro.

4 Mapa de uso das terras da bacia hidrográfica do Ribeirão do

Ceveiro. Ano base: 1995 .53

5 Semivariograma para a profundidade do solo na bacia hidrográfica do Ribeirão do Ceveiro. Modelo esférico: parâmetros $(\mathrm{Co}=0,3 ; \mathrm{Cl}=0,8$; $\mathrm{a}=1.400$ ). .56

6 Profundidade do solo na bacia hidrográfica do Ribeirão do Ceveiro. .56

7 Fator erosividade da precipitação e da enxurrada para a bacia hidrográfica do Ribeirão do Ceveiro ( $P I_{l}:$ Mapa do fator $R$ ).

8 Fator de cobertura e manejo por categoria de uso da terra da bacia do Ribeirão do Ceveiro ( $\mathrm{PI}_{2}$ : Mapa do fator $\left.\mathrm{C}\right)$.

9 Fator práticas de controle da erosão para as categorias de uso da terra da bacia do Ribeirão do Ceveiro ( $P I_{3}$ : Mapa do fator $P$ ).

10 Semivariograma para a erodibilidade do solo da bacia hidrográfica do Ribeirão do Ceveiro. Modelo exponencial: parâmetros $\left(C_{0}=0,5\right.$; $\mathrm{C}_{1}=0,65 ; \mathrm{a}=700$ )

11 Fator erodibilidade dos solos para a bacia hidrográfica do Ceveiro. ( $\mathrm{PI}_{4}:$ Mapa do fator $\mathrm{K}$ ).

12 Fator topográfico para a bacia hidrográfica do Ribeirão do Ceveiro (PI : Mapa do fator $L S$ ).

13 Taxas estimadas de perda de solo na bacia hidrográfica do Ceveiro 
(A, em Mg ha ${ }^{-1}$ ano $^{-1}$ ) e ocorrência (área, em hectares).

14 Gráfico de dispersão da perda de solo na bacia do Ceveiro em relação à variação do fator LS.

15 Gráfico de dispersão da perda de solo na bacia do Ceveiro em relação à variação do fator $K$

16 Interpretação das taxas de erosão pelo critério de tolerância de perda de solo

17 Panorama da erosão na bacia do Ceveiro: áreas em situação de conservação, de degradação, e sob impacto irreversível instalado, já no tempo atual.

18 Mapa do Tempo de Vida da bacia do Ceveiro, considerando a profundidade crítica de $50 \mathrm{~cm}$

19 Mapa do Tempo de Vida da bacia do Ceveiro, considerando a profundidade crítica de $100 \mathrm{~cm}$.

20 Índices do Tempo de Vida: nas áreas com cana-de-açúcar; nas áreas de não cana-de-açúcar e, na bacia como um todo (profundidade crítica $=50 \mathrm{~cm}$ )

21 Índices do Tempo de Vida: nas áreas com cana-de-açúcar; nas áreas de não cana-de-açúcar e, na bacia como um todo (profundidade critica $=100 \mathrm{~cm}$ ). 


\section{LISTA DE TABELAS}

Página

1 Uso das terras na bacia hidrográfica do Ribeirão do Ceveiro: categorias e áreas de ocorrência.

2 Caracterização meteorológica de um ano normal em Piracicaba: valores médios mensais de uma série de 80 anos.

3 Comprimento máximo da vertente (em metros), em função da declividade (de acordo com Bertoni \& Lombardi Neto (1990)

4 Comprimento da vertente (em metros), por classe de declividade, para a área de cana-de-açúcar na bacia hidrográfica do Ceveiro

5 Fator $C$ por categoria de uso da terra da bacia hidrográfica do Ceveiro

6 Distribuição da profundidade dos solos na bacia hidrográfica do Ribeirão do Ceveiro, em relação à área acumulada .55

7 Parâmetros estatísticos de nove atributos físicos e químicos dos solos da bacia hidrográfica do Ribeirão do Ceveiro.

8 Perda de solo estimada $\left(\mathrm{A}, \mathrm{Mg} \mathrm{ha}^{-1} \mathrm{ano}^{-1}\right)$ nas áreas de $n \tilde{a} o$ cana-de-açúcar da bacia do Ceveiro e área de ocorrência. .68

9 Perda de solo estimada ( $\left.\mathrm{A}, \mathrm{Mg} \mathrm{ha}^{-1} \mathrm{ano}^{-1}\right)$ nas áreas de cana-de-açúcar da bacia do Ceveiro e área de ocorrência.

10 Perda de solo estimada $\left(\mathrm{A}, \mathrm{Mg} \mathrm{ha}^{-1}\right.$ ano $\left.^{-1}\right)$ na bacia hidrográfica do Ceveiro e área de ocorrência

11 Impacto da erosão do solo na bacia do Ceveiro: resumo da situação de conservação ou de degradação, nas áreas com cana-de-açúcar, nas áreas com usos menos intensivos e na bacia como um todo. 


\title{
ESTIMATIVA DA EROSÃo DO SOLO E AVALIAÇÃO DO SEU IMPACTO NA MICROBACIA DO CEVEIRO (PIRACICABA, SP), ATRAVÉS DO ÍNDICE DE TEMPO DE VIDA
}

\author{
Autora: Mara de Andrade Marinho Weill \\ Orientador: Dr. Gerd Sparovek
}

\section{RESUMO}

A erosão acelerada do solo é o processo que, isoladamente, mais contribui para a degradação da qualidade das terras aráveis em todo o mundo, além de reconhecidamente, constituir a principal fonte não pontual de poluição dos recursos hídricos superficiais. Em vista da importância tanto do diagnóstico da erosão instalada, quanto da previsão de instalação de novos impactos, este trabalho foi concebido tendo por objetivo central desenvolver um índice quantitativo, com valor prognóstico, para ser aplicado como uma ferramenta de planejamento, na avaliação do impacto da erosão acelerada de terras agrícolas.

Foi efetuado um estudo de caso na microbacia do Ceveiro, no município de Piracicaba (SP), uma área intensivamente cultivada com a cultura da cana-de-açúcar. A condição local do clima, dos solos e das práticas de manejo aplicadas, é representativa da situação encontrada na região produtora de cana-de-açúcar em Piracicaba e municípios vizinhos.

O trabalho foi executado no ambiente IDRISI, um sistema de informação geográfica. As taxas atuais de erosão foram estimadas pela USLE, com ajuste dos fatores do modelo à realidade local. A análise da influência relativa dos fatores da USLE, na variação observada nas taxas estimadas de erosão, foi efetivada através de testes de médias, gráficos de dispersão e simulações. Com base nas estimativas atuais de perda de solo, em uma taxa presumida de renovação dos solos, e na profundidade "excedente" do solo, foi calculado um índice de sustentabilidade, denominado Índice de Tempo de Vida, que é uma função da posição no terreno e remete ao tempo para instalação de impacto irreversível. 
Os resultados da modelagem da erosão mostraram que cerca de dois terços da área da microbacia, ocupados com cana-de-açúcar e cultura anual, encontramse em processo intenso de degradação da qualidade de seus recursos naturais, em especial dos solos. As taxas estimadas de perda de solo são muito elevadas, variando em torno da média de $58 \mathrm{Mg} \mathrm{ha}^{-1}$ ano $^{-1}$. Nas áreas ocupadas com mata, reflorestamento $\mathrm{e}$ pastagens, as taxas estimadas são pequenas, variando ao redor de $2 \mathrm{Mg} \mathrm{ha}^{-1}$ ano $^{-1}$. A modelagem da erosão revelou a cultura da cana-de-açúcar como o uso impactante na bacia.

$\mathrm{O}$ fator $\mathrm{C}$ definiu a ordem de grandeza das estimativas. Para uma mesma categoria de uso, o fator LS respondeu pela maior parte da variação observada nas taxas estimadas de perda de solo. A análise da influência da erodibilidade do solo, ou fator $\mathrm{K}$, foi inconclusiva. Mas, os resultados de uma simulação indicaram que sua influência na variação das taxas estimadas de perda de solo foi menor do que aquela caracterizada para o fator LS.

A aplicação do índice de tempo de vida, como um critério de avaliação do impacto da erosão, revelou que mantido o sistema atual de manejo da cultura da cana-de-açúcar na bacia, a erosão acelerada deverá condicionar a exaustão da base do recurso solo, em cerca de $80 \%$ da área, em até 200 anos. A aplicação do índice de tempo de vida também permitiu a) caracterizar situações de impacto irreversível já instalado; b) inferir sobre a intensidade do processo.

A interpretação da erosão baseada unicamente no critério de tolerância de perda de solo, foi insuficiente para gerar a informação necessária ao adequado planejamento do uso da terra em bases sustentáveis. 


\title{
SOIL LOSS ESTIMATION AND EROSION IMPACT EVALUATION ON CEVEIRO WATERSHED (PIRACICABA, SP), USING THE LIFE-TIME INDEX
}

\author{
Author: Mara de Andrade Marinho Weill \\ Adviser: Dr. Gerd Sparovek
}

\section{SUMMARY}

Soil loss from soil erosion is perhaps the most potent single factor contributing to the agricultural land degradation worldwide. It is also the main nonpoint pollution source on superficial water resources. Facing the importance of soil erosion diagnosis, and the necessity of foreseen the new impacts installation, this work was conceived having as prime goal develop a quantitative index, to be applied as a planning tool on evaluation and prediction of soil erosion impacts on agricultural land.

This work was carried out as a study case, in the Ceveiro watershed, in Piracicaba (SP), Brazil, an intensively cultivated sugarcane area. The climate, soil conditions and management practices are very similar to the other applied in the regional scale of Piracicaba area specialized in sugarcane production.

The IDRISI environment, a geographic information system, was used in the present work. In other to estimate soil loss rates, the USLE model was applied, based on calibrated values to local conditions. Statistical analysis dealing with difference between means, dispersion analysis, and scenario simulation were made to evaluate the relative influence of each USLE factor on estimated soil loss rates. It was developed an index, called Life-Time Index, as a criterion for the soil erosion impact. The index was based on present soil loss rates, soil renewable rate, and "available" soil depth. It was conceived as a function of the local terrain position, and that it accounts for the establishment time that an irreversible impact will be installed.

The results of soil erosion modeling demonstrated that two thirds of the watershed area, with sugarcane and annual crop, were in an intensive process of 
degradation. Estimated soil losses were in order of $58 \mathrm{Mg} \mathrm{ha}^{-1}$ year ${ }^{-1}$. In forest and rangeland areas, the estimated soil loss rates were very low with average value close to $2 \mathrm{Mg} \mathrm{ha}^{-1}$ year $^{-1}$. The erosion modeling revealed that the sugarcane was very impacting when used in the soil exploitation.

The $\mathrm{C}$ factor has defined the magnitude of soil loss rates. For a given land utilization type, LS factor was responsible for the major portion of observed variation on soil loss estimation rates. The analysis of the influence of soil erodibility, or $\mathrm{K}$ factor, was inconclusive. But, simulated results indicated that its influence on estimations was smaller than that attributed to LS factor.

The Life-Time Index applied as an evaluation criterion for the soil erosion impact revealed that maintaining the present land use and management production system, with sugarcane as the main crop, the accelerated erosion would exhaust the natural soil resource base. About $80 \%$ of the entire area will reach the condition of irreversible impact in a time span of 200 years. The use of the Life-Time Index also allowed the following conclusions: a) it successfully indicates situations where irreversible impacts were already installed; and b) it was possible to infer about the erosion process intensity.

Soil erosion interpretation based only upon classic soil loss tolerance criteria, is not sufficient to fulfil with the necessary information for adequate planning of the land use on sustainable basis. 


\section{INTRODUÇÃO}

A agricultura sobrecarrega muitos dos processos reguladores dos ecossistemas naturais, constituindo uma das mais poderosas forças antropogênicas de transformação das paisagens. Historicamente, o objetivo primário do manejo de agroecossistemas, tem sido o de maximizar o fluxo de energia e materiais de consumo humano extraído diretamente na forma de grãos ou de fibras ou, indiretamente, através da criação de animais (Cox, 1984).

A maior parte da história da pesquisa agrícola e da aplicação do manejo se ligou, portanto, à busca pelo aumento da produtividade. Na década de 40 , nos países industrializados, a aplicação intensiva de insumos, especialmente fertilizantes e pesticidas, proporcionou um acentuado aumento nas produções. No entanto, essas técnicas, mais a mecanização e a irrigação intensivas, também proporcionaram consequiências indesejáveis. Efeitos deletérios têm acompanhado a prática da agricultura, que hoje é largamente citada como fonte de poluição (Soil and Water Conservation Service, 1995).

No contexto da agricultura intensiva, a erosão acelerada do solo surge como um grande fator de degradação, e a principal fonte de poluição não pontual. É reconhecido o fato de que o crescimento populacional ou econômico de uma região, promove a intensificação do uso do solo e o aumento das perdas de solo por erosão (Lal, 1994). A aceleração do processo erosivo normalmente inicia com a remoção da cobertura vegetal original para implantação do agroecossistema. $O$ manejo impróprio de terras produtivas e a exploração intensiva de terras marginais agravam ainda mais o problema.

A erosão acelerada se caracteriza por taxas excessivas de perda de solo, muito maiores do que as taxas de formação ou de renovação. Considerando que o solo 
não é um recurso renovável, em uma escala de tempo compatível com a da existência Humana (Jenny, 1980), a degradação da qualidade do solo por erosão acelerada, caracteriza um impacto irreversível sobre a qualidade do ambiente. Além disso, a poluição das águas superficiais por sedimentos, em conjunto com a contaminação das águas subsuperfíciais por lixiviação de agroquímicos, constituem duas grandes questões ambientais da atualidade, diretamente relacionadas com a prática da agricultura moderna (Soil and Water Conservation Service, 1995; Schaller,1989; Stinner \& House, 1989).

As elevadas perdas de recursos não renováveis, aliadas à destruição de ecossistemas naturais, conduziram a um sentimento geral de que a relação atual homemnatureza é insustentável (Kruseman et al., 1996). O maior desafio da agricultura mundial hoje é o de prover alimentos, fibras e matérias-primas industriais para bilhões de pessoas, sem comprometer nem colocar em risco a produtividade futura de nossos recursos naturais (Madigan, 1991). O momento atual caracteriza uma busca por sistemas mais sustentáveis de produção.

O planejamento do uso das terras e o planejamento ambiental ocupam um lugar destacado no diagnóstico da situação presente em dada área, na definição de alternativas de uso sustentável, e sobretudo, na identificação de riscos potenciais de degradação permanente. Atrelado ao conceito de sustentabilidade, a maior qualidade que se espera do planejamento, é que assuma um caráter prognóstico: sustentabilidade faz pouco sentido após o fato. No planejamento voltado ao diagnóstico da erosão, há uma carência de critérios operacionais, que permitam o estabelecimento de previsões. A forma tradicional de se interpretar a erosão instalada, com base exclusiva em critérios de tolerância de perda de solo, não permite considerações acerca do que se pode esperar para o futuro, mostrando-se, portanto, pouco eficiente às finalidades do planejamento sustentável.

Identificados um problema (degradação das terras e da qualidade ambiental por erosão acelerada) e uma opção promissora de abordagem do mesmo (planejamento atrelado a um critério operacional de sustentabilidade), o presente trabalho foi idealizado chamando para si a tarefa de desenvolvimento e proposição de um novo critério de avaliação de impacto da erosão acelerada do solo, partindo da 
hipótese de que o critério atual, baseado apenas na tolerância de perda de solo, não é satisfatório. Para desenvolvimento da pesquisa, foi escolhida a escala de microbacia hidrográfica, por seu caráter simultaneamente regional, bem de acordo com os trabalhos em planejamento, e sistêmico, totalmente apropriado aos estudos de erosão.

Tomando por base as considerações precedentes, definiram-se os objetivos gerais do trabalho como sendo os de: 1) caracterizar a erosão instalada em uma microbacia hidrográfica; 2) avaliar os impactos já instalados; 3) prever os riscos de instalação de novos impactos no futuro. Para atender a esses objetivos gerais, o trabalho foi desenvolvido em duas etapas.

A primeira etapa, relativa à caracterização da erosão instalada, foi desenvolvida para atender aos objetivos específicos de: a) estimar as taxas atuais de erosão do solo na microbacia; b) definir a importância relativa da variação dos fatores locais, nas taxas estimadas de perda de solo; e, c) identificar a ordem de importância dos fatores condicionantes da erosão para a área em questão. A segunda etapa, relativa à interpretação dos resultados obtidos, foi desenvolvida para atender aos objetivos específicos de: d) desenvolver um critério operacional de avaliação do impacto da erosão, na forma de um índice de sustentabilidade, dotado de valor prognóstico; e) avaliar o impacto da erosão na área da pesquisa, e a evolução esperada, adotando como critério, o indice de sustentabilidade proposto; f) comparar a interpretação dos resultados obtida com base no indice de sustentabilidade (critério funcional), com a interpretação baseada no critério clássico de tolerância de perda de solo (critério estático). 


\section{REVISÃO DE LITERATURA}

\subsection{Sustentabilidade e uso sustentável em agricultura}

A preocupação relativamente recente com a degradação ambiental decorrente da ação antrópica, tem sido traduzida pelo termo sustentabilidade. Aplicado em agricultura, o movimento de reforma iniciado nos Estados Unidos, Canadá e Europa Ocidental, marcou a busca por práticas agrícolas poupadoras do ambiente e sistemas "sustentáveis" de produção (Hansen, 1996). Encontra-se na literatura diversos conceitos, definições e abordagens do termo sustentabilidade em agricultura. $O$ tema foi objeto de revisão por vários autores (Hansen, 1996; Park \& Seaton, 1996; Kruseman et al., 1996), e cada vez mais tem sido empregado por pesquisadores, políticos e membros informados do público (Park e Seaton, 1996).

O conceito de sustentabilidade é complexo, geralmente centrado no Homem, mas envolvendo sua interação com os sistemas naturais, em processos de longa duração (Park \& Seaton, 1996). Sustentabilidade e uso sustentável não devem ser vistos exclusivamente em termos ambientais, mas também à luz dos condicionantes econômicos, políticos, legais, e institucionais (Kruseman et al., 1996).

O conceito que interpreta sustentabilidade como uma filosofia é facilmente apreendido pelo senso comum. "Desenvolvimento Sustentável", conforme definido pela Comissão Mundial para o Ambiente e o Desenvolvimento, é um modelo capaz de manter, através das gerações, a habilidade da humanidade em satisfazer suas necessidades, sem comprometer ou reduzir as possibilidades de desenvolvimento das gerações vindouras (Park \& Seaton, 1996). O modelo sustentável se baseia em eficiência econômica, que é alcançada com a melhor alocação possível de recursos escassos, na igualdade social, que se traduz por uma justa distribuição da renda, e no equilíbrio agro- 
ecológico, caracterizado por uma variação favorável no estoque dos recursos naturais.

Diversos autores sinalizam, no entanto, para a importância de expressar sustentabilidade como um critério operacional para guiar as mudanças em agricultura (Hansen, 1996), avaliar os sistemas de produção (Kruseman et al, 1996), ou orientar as pesquisas em conservação ambiental (Park \& Seaton, 1996).

A concepção da sustentabilidade como um critério operacional deve ser objetiva. Para cada nível de análise, em função dos objetivos, mudam os indicadores a serem avaliados. No nível regional ou nacional, o conceito de sustentabilidade deve refletir objetivos sociais ou públicos. No nível da propriedade agrícola, sustentabilidade se relaciona com a viabilidade econômica do sistema doméstico de produção, e sua capacidade de longo prazo em consumir recursos e produzir benefícios. E no nível local, ou da parcela de produção, a sustentabilidade se relaciona com os processos que afetam o sortimento de recursos, que podem ser descritos por uma função, e caracterizados por taxas e variáveis de estado (Kruseman et al., 1996).

No caso da sustentabilidade aplicada ao estudo da erosão, o nível de análise é local, e os indicadores se relacionam com a interpretação das estimativas da erosão instalada.

Hansen (1996) apontou barreiras conceituais e metodológicas que dificultam a caracterização objetiva de sustentabilidade, para servir como um critério a guiar as mudanças em agricultura. Para o autor, uma caracterização objetiva deve ser simultaneamente literal, orientada para o sistema, quantitativa, preditora e diagnóstica. A interpretação literal do termo, define sustentabilidade como a habilidade em se manter ou a habilidade em continuar, isto é, a pressuposição de continuidade através do tempo é intrínseca ao conceito. A caracterização orientada para o sistema agrícola, comporta limites, componentes, contexto no qual opera, e escalas temporais e espaciais específicas; o que resulta em objetividade, que é essencial para guiar a mudança. Sustentabilidade não deve ser tratada como uma propriedade discreta do sistema, que admite somente duas possibilidades: "sistema sustentável" ou "sistema não sustentável". Comparações entre sistemas agrícolas ou proposições alternativas somente são possíveis quando a sustentabilidade é tratada como uma propriedade contínua do sistema (Lynam 
\& Herdt, 1989; Hansen, 1996). Por esta razão, a caracterização da sustentabilidade deve ser quantitativa. Uma vez que a sustentabilidade trata de mudanças futuras no sistema, sua caracterização deve ser preditora do futuro, ao invés de meramente descritiva do presente ou do passado. Sustentabilidade tem pouco significado após o fato. A variabilidade do ambiente em que se insere o sistema agrícola deve ser considerada como determinante da sustentabilidade e um componente das predições. E finalmente, a caracterização da sustentabilidade deve ser diagnóstica. O diagnóstico é facilitado quando se dispõe de uma medida integradora, que agregue o conjunto possível de fatores determinantes, em uma medida singular e integrada de resposta do sistema (Hansen, 1996).

\subsection{Planejamento do uso das terras e planejamento ambiental}

O reconhecimento de uma necessidade de mudança ou a existência de pressões envolvendo usos competitivos para uma mesma terra, estão na base do processo de planejamento do uso da terra (FAO, 1976).

O termo "terra" designa o conjunto de atributos relativos aos seus recursos naturais, representados pelo clima, fauna, flora, relevo, águas, solos e rochas (Mabbutt, 1968; Young, 1976; Lal, 1997). A FAO (1976) deu uma abrangência maior ao termo, incluindo a ação antrópica na definição de terra.

A terra é um recurso essencial para a agricultura. As terras aráveis em todo o mundo constituem, no entanto, um recurso finito, disponível somente em uma quantidade fixa. Estima-se que $78 \%$ da superficie total do globo seja inapta para fins agrícolas. Para os $22 \%$ restantes, considerados aptos, estima-se que $13 \%$ sejam de baixo potencial de produção, $6 \%$ de médio potencial, e apenas $3 \%$ de alto potencial produtivo, para produção intensiva de culturas (Lal \& Stewart, 1992).

A função primordial do planejamento do uso das terras é guiar as decisões de modo que a alocação dos recursos naturais priorize seu melhor uso possível e garanta, simultaneamente, sua conservação para o futuro (FAO, 1976). É implícito ao processo o objetivo de conservação e de melhoria dos recursos naturais.

Num contexto mais amplo, planejamento ambiental foi definido por 
Davis (1985) como sendo o processo de planejamento do uso da terra ampliado para incluir considerações acerca dos impactos dos usos indicados sobre o ambiente físico e social circundante. O planejamento ambiental e o planejamento do uso das terras são, portanto, complementares.

A qualidade ambiental é uma condição necessária para manutenção ou melhoria da qualidade de vida. Os fatores intervenientes na qualidade ambiental são de natureza social ou biofísica. Os fatores sociais dizem respeito à maior ou menor facilidade de acesso a empregos e a serviços, e ao maior ou menor grau de harmonia social ou conflitos. Já os fatores biofísicos, relacionam-se com os níveis de poluição e/ou degradação do ar, da água, do solo, da vegetação, da fauna e dos recursos estéticos da paisagem (Cocks, 1985).

A degradação das terras é um processo complexo, que se relaciona com a diminuição da qualidade ou aptidão atual e/ou futura das terras em manter a vida (Oldeman et al., 1991; Lal \& Stewart, 1992). Em condições naturais, o processo normalmente ocorre lentamente, pela ação de fatores climáticos e geológicos, não chegando a ser claramente perceptível. A interferência humana, no entanto, intensifica e agrava grandemente o processo (Graaf, 1996). A degradação acelerada de terras agrícolas ocorre nos locais onde a capacidade natural de auto-regulação dos sistemas foi ultrapassada. A ocorrência de degradação é um sintoma de uso e manejo mal conduzidos, indicativo da necessidade de planejamento.

O planejamento do uso das terras e o planejamento ambiental ocupam, um lugar destacado no diagnóstico da situação de degradação presente em dada área, na definição de alternativas de uso sustentável, e sobretudo, na identificação de riscos potenciais de degradação permanente. Uma vez que tempo e recursos são normalmente limitantes, grande parte das iniciativas em planejamento se concentra sobre a melhoria ou proteção da qualidade ambiental, em relação a um pequeno número de problemas ambientais significativos (Cocks, 1985).

Dentre os processos que ocasionam degradação, a erosão acelerada do solo aparece como aquele que, isoladamente, mais contribui para a degradação das terras produtivas em todo o mundo (Bennet \& Loundermilk, 1938; El-Swaife \& Dangler, 
1982; Lal, 1994). Priorizar o problema da erosão do solo é, portanto, de grande significado. Entretanto, no planejamento voltado ao diagnóstico da erosão, há uma carência de critérios operacionais, que permitam o estabelecimento de previsões. A forma tradicional de se interpretar a erosão instalada, com base exclusiva no critério de tolerância de perda de solo, tema que será discutido adiante, não permite considerações acerca do futuro, mostrando-se, portanto, pouco eficiente às finalidades do planejamento sustentável.

\subsubsection{Importância do solo e da água nos agroecossistemas}

O solo é um recurso essencial da terra, não renovável e limitado (Schertz, 1983). No sistema solo, da interação entre o que lhe é intrínseco (partículas minerais e orgânicas dispostas em uma estrutura) e agentes externos (água, ar, luz, organismos e outros veículos de energia), decorrem propriedades que conferem ao sistema a capacidade de desempenhar múltiplas funções. Destacam-se as funções do solo como meio natural ao crescimento e desenvolvimento de plantas superiores e como filtro natural, com elevada capacidade de tamponamento (Blum, 1997; Lal, 1997).

Do ponto-de-vista hidrológico, o solo é um importante reservatório de água doce. Em função de suas propriedades de infiltração, retenção e redistribuição de água, eventos descontínuos como as precipitações, adquirem continuidade no corpo do solo, na forma de um fluxo de água para as raízes das plantas (Kutílek \& Nielsen, 1994). A qualidade dos recursos hídricos, no tempo e no espaço, é grandemente influenciada pelos processos hidrológicos que se estabelecem no sistema solo. A fina camada de solo que cobre a superficie terrestre representa a diferença entre a sobrevivência e extinção para a maior parte da vida terrestre. À semelhança da água, o solo é um recurso natural vital, essencial para a civilização, mas diferente da água, o solo não é renovável em uma escala de tempo humana (Jenny, 1980).

Do ponto-de-vista energético, o solo é um meio único, podendo ser considerado um reservatório de energia química. A energia química de origem orogenética, que é herdada do material de origem através dos minerais primários, não é renovável. A energia química estocada na biomassa e em todas as formas de carbono 
orgânico presentes, representa o estoque renovável de energia do solo (Blum, 1997). Com base nesse conceito de energia aplicado ao solo, a degradação do solo pode ser definida como um processo caracterizado pela perda ou redução de seu estado energético. Como todas as funções e usos do solo se baseiam em energia, também pode ser dito que a degradação do solo é igual a uma perda ou redução de suas funções e de seus usos (Blum, 1997).

Há uma conscientização crescente de que o solo é um componente criticamente importante da biosfera terrestre, funcionando não somente para a produção de alimentos e fibras, mas também na manutenção da qualidade do ambiente local, regional e global (Doran, Sarrantonio \& Liebig, 1996). O processo erosivo, ao condicionar a perda de materiais do corpo do solo e a desorganização de sua estrutura, atua como um importante agente de degradação. No planejamento e na avaliação de terras, os solos recebem especial atenção pela possibilidade de manejo de grande parte de seus atributos, o que favorece os objetivos das ações humanas.

A água, por sua vez, é uma das substâncias mais comuns e importantes da superfície terrestre, sendo essencial para a existência de vida na Terra. Nos dias atuais, a disponibilidade de água limita, não apenas o crescimento das plantas, mas o crescimento de indústrias e de cidades, sabendo-se que o uso indevido poderá comprometer o futuro da humanidade, caso não se inicie de imediato um processo global de sensibilização das comunidades e de políticas de recuperação e uso racional (Kramer \& Boyer, 1995). A importância ecológica da água resulta de sua importância fisiológica. Praticamente todo processo da planta é afetado direta ou indiretamente pelo suprimento de água. A água desempenha papéis essenciais na planta como constituinte dos tecidos vegetais, como solvente, como reagente e na manutenção da turgidez celular (Kramer \& Boyer, 1995). Onde a temperatura permite o crescimento de plantas, o controle do tipo e exuberância da vegetação vem a ser da quantidade e distribuição da precipitação. A disponibilidade de água representa o fator ambiental que isoladamente mais contribui para o padrão e distribuição dos vários tipos de vegetação sobre a superfície terrestre.

Em conjunto, clima e solo definem em grande extensão a capacidade de suporte e de desenvolvimento de plantas superiores, o tipo de cobertura vegetal, e as 
possibilidades de uso sustentável de uma área. A produção excessiva de sedimentos pela erosão acelerada, tem promovido extensivamente o assoreamento, a poluição e a eutrofização das águas superficiais, com prejuízo da quantidade e da qualidade dos recursos hídricos. Em um tempo em que o uso competitivo das terras, para fins agrícolas, urbanos e industriais, intensifica-se a uma taxa elevada, o controle da erosão continua sendo um fator essencial em direção ao uso sustentável.

\subsection{Erosão acelerada do solo e degradação de terras}

\subsubsection{Relevância do problema}

A erosão acelerada do solo tem sido amplamente reconhecida como um sério problema global de degradação de terras e uma ameaça ao bem-estar da humanidade (Lal \& Stewart, 1990 a). Estima-se que a erosão acelerada tenha destruído irreversivelmente algo em torno de 430 milhões de hectares de terras produtivas em diferentes países (Lal, 1990 b). No início dos anos 80, estimava-se que a degradação de terras agrícolas por erosão do solo e outros fatores conduzia a uma perda irreversível na produtividade de cerca de 6 milhões de hectares de terra fértil anualmente em todo o mundo (Lal, 1994). Uma década depois, as estimativas situavam entre 5 e 7 milhões de hectares de terras aráveis perdidos todo ano pela degradação do solo (respectivamente $0,3 \%$ e $0,5 \%$ da área total cultivada no mundo), e uma projeção de perda para o ano 2000 da ordem de 10 milhões de hectares ao ano, ou de cerca de $0,7 \%$ da área cultivada (Lal \& Stewart, 1992). No início dos anos 90, o Centro Internacional de Referência e Informação em Solos estimou que a degradação do solo, induzida pela interferência humana, afetava $24 \%$ da área habitada do planeta (Lal, 1994). Para a América do Sul, foi associada a cifra de $18 \%$ de degradação da área ocupada, contra $12 \%$ na América do Norte, $26 \%$ na Europa, $27 \%$ na África, $31 \%$ na Ásia e $19 \%$ na Oceania. A extensão global de terras da América do Sul, então afetadas pela erosão hídrica, atingia a cifra de 123 milhões de hectares, e pela erosão eólica , 42 milhões de hectares (Lal, 1994).

$\mathrm{Na}$ região tropical úmida, problemas severos ocorrem quando a terra é desmatada para cultivo e fica exposta a chuvas intensas, sendo geralmente aceito que a erosão traz conseqüências mais sérias do que em relação a qualquer outra região (El- 
Swaife \& Dangler, 1982). No Brasil, de acordo com dados apresentados por Bertoni \& Lombardi Neto (1990), a perda anual de solo por erosão acelerada é de cerca de 500 milhões de toneladas, sendo que o Estado de São Paulo responderia por cerca de $25 \%$ da perda nacional, ou por 130 milhões de toneladas de terra, perdidas por erosão decorrente do uso intensivo ou indevido.

\subsubsection{Definição e tipos de erosão acelerada}

A erosão (do Latim, erodere), manifesta-se pela deterioração da superficie do solo, por atuação de forças exógenas, em especial, água, vento e gelo. Essa perturbação na superfície do solo é acompanhada pela remoção de partículas. A força motriz do processo é a energia cinética dos agentes erosivos, água e vento. Depois, com a diminuição progressiva da energia do agente erosivo, dá-se a deposição do material erodido (Holy, 1980). A erosão é, portanto, o processo pelo qual há remoção de uma massa de solo de um local, e sua conseqüente deposição em outros locais. É um processo natural, praticamente impossível de ser estancado, comumente difícil de ser controlado, e facilmente acelerado pelo homem (Dregne, 1982).

A erosão hídrica é a erosão causada pela ação da água, proveniente de chuva, irrigação ou enxurrada (Laflen \& Roose, 1997). Os principais fatores condicionantes da aceleração do processo erosivo se relacionam com o desmatamento ou remoção da cobertura vegetal original, com o manejo impróprio de solos produtivos, com a exploração inadequada de terras marginais, com a pressão de ocupação das terras por usos competitivos, com o uso intensivo de áreas com elevado potencial natural de erosão, e sobretudo, com a falta de planejamento da ocupação (Dregne, 1982; Pinto, 1991). A extensão e grau de severidade da erosão acelerada é função de fatores associados à fisiografia, ao clima, ao solo, à cobertura vegetal natural presente, e ao tipo de uso e manejo agrícola instalado. Os principais fatores fisiográficos associados ao processo erosivo são a posição na paisagem, a inclinação da encosta, o comprimento e a forma da vertente e a rugosidade da superfície. Em relação ao clima, são relevantes a quantidade, a distribuição, a intensidade e a energia das precipitações, os ventos e as variações da temperatura. Os fatores edáficos se relacionam com o tipo de solo presente; com a granulometria, estrutura e grau de agregação dos horizontes superficiais; com a 
permeabilidade do perfil; e com a capacidade de infiltração e de retenção de água no solo (Hudson, 1971; Wischmeier \& Smith, 1978; Pimentel et al., 1976; Clark II et al., 1985).

$\mathrm{Na}$ erosão hídrica, a perda de solo é função da exposição da sua superfície à ação do impacto da gota, ou do desprendimento de material devido a ação da enxurrada. De acordo com o processo, a erosão hídrica é subdividida em dois subtipos: a) erosão entre-sulcos ou areolar; e, b) erosão em sulcos ou linear. A erosão entresulcos é melhor descrita como um processo de desprendimento de partículas do solo pelo impacto das gotas de chuva ou da água de irrigação em um solo descoberto (Laflen \& Roose, 1996; Mutchler, Murphree \& McGregor, 1994). Após a saturação da camada mais superficial, forma-se um fluxo superficial, no qual as partículas ficam em suspensão, podendo ser transportadas (Clark II et al., 1985). As forças e energias atuantes no processo derivam do impacto das gotas (de chuva ou de irrigação) sobre a superfície do solo descoberto e do fluxo superficial próximo ao local onde o impacto ocorreu. A liberação para pequenos sulcos ocorre muito próximo aos locais de impacto, estando intimamente relacionada com a energia cinética destas gotas (Laflen \& Roose, 1997). O processo geralmente envolve curtas distâncias, um metro ou pouco mais, a partir do ponto de impacto da gota. O material liberado atingindo canais próximos ao ponto de origem, pode então ser levado pela enxurrada para pontos mais distantes, em cotas inferiores. Se não há fluxo no canal, o material da erosão entre-sulcos permanece próximo ao ponto de desprendimento (Laflen \& Roose, 1997). O material liberado pela erosão entre-sulcos apresenta como característica fundamental, uma maior concentração das frações mais finas, comparativamente à granulometria do solo original. Isto resulta do fato de que a energia associada ao fenômeno normalmente é suficiente apenas para transportar as partículas mais leves do solo, que se mantém suspensas e propícias ao deslocamento, mesmo com quantidade limitada de água. A erosão entre-sulcos é constante ao longo da encosta onde o solo, as características da superficie do terreno, a cobertura vegetal e a energia e tamanho das gotas de chuva se mantém constantes (Laflen \& Roose, 1997).

A erosão em sulcos é o processo de desprendimento e transporte de solo 
devido à enxurrada. Geralmente, a maior parte da erosão visível no campo, é devida à erosão em sulcos. A erosão em sulcos aumenta com o aumento do volume da enxurrada. O volume da enxurrada é uma função não apenas da intensidade da precipitação, mas da posição na paisagem, do tipo de solo e da cobertura vegetal, e do comprimento e inclinação da encosta. Onde o terreno se constitui por encostas curtas, a maior parte da erosão presente se relaciona com a erosão entre-sulcos. À medida que as encostas se alongam, o processo de erosão em sulcos passa a ser dominante (Laflen \& Roose, 1997). $\mathrm{Na}$ erosão em sulcos, o material que é desprendido e deslocado pela ação da enxurrada apresenta granulometria semelhante ao solo original, não sendo concentrado em relação às partículas mais finas.

Por serem processos distintos, os métodos de avaliação e de controle da erosão em sulcos e entre-sulcos são diferentes, assim como podem ser diferenciados seus efeitos na degradação do solo (Laflen \& Roose, 1997). A erosão entre-sulcos é considerada como sendo a maior fonte de poluição não pontual de águas superficiais, muito embora possa haver contribuição de sedimentos da erosão em sulcos. A erosão em sulcos é muito importante localmente, na área de produção. No controle da erosão entresulcos, busca-se prevenir o impacto da gota de chuva sobre o solo descoberto, e a medida principal de controle vem a ser a cobertura do solo. $\mathrm{Na}$ erosão em sulcos, o agente é a enxurrada. O controle visa 1) prevenir a concentração da enxurrada; 2) diminuir seu volume e a energia cinética associada; e 3) favorecer a infiltração da água ou sua rápida drenagem, para fora da área de produção.

\subsubsection{Impactos diretos e indiretos da erosão acelerada}

Pelo processo erosivo, ocorrem perdas da porção superficial do solo, que é onde se concentram a matéria orgânica e os nutrientes. A erosão, portanto, condiciona a perda progressiva da porção mais fértil do solo. A espessura do solo diminui e podem se formar sulcos, cuja freqüência e dimensões no terreno, restringem ou impedem a motomecanização. Por conseguinte, a potencialidade da terra como um todo, decresce. A erosão acelerada como um agente de degradação, promove alterações adversas de importantes propriedades físicas, químicas e biológicas dos solos, que respondem por 
sua habilidade em desempenhar múltiplas funções no ambiente, limitando ou reduzindo essa habilidade (Lal, 1997; Blum, 1997).

A diminuição da qualidade multifuncional do solo, mais a ocorrência de dano físico ou destruição de plantas, podem ser considerados impactos diretos da erosão no agroecossistema (Lal, 1997; Pierce \& Lal, 1994; Clark II et al., 1985). Do ponto-devista ambiental, a erosão acelerada dos solos, especificamente a erosão entre-sulcos, é reconhecidamente a principal fonte não pontual de degradação das águas superficiais por nitratos, fosfatos e agroquímicos (McCool \& Renard, 1990; Clark II et al., 1985).

A erosão entre-sulcos é de importância nos estudos de poluição ambiental, à medida em que os sedimentos liberados, enriquecidos com argila, matéria orgânica, moléculas e íons adsorvidos, são transportados em suspensão nas enxurradas para as partes mais baixas, atingindo os canais fluviais e reservatórios, onde promovem assoreamento, eutrofização e poluição. Estes seriam os principais efeitos indiretos da erosão das terras agrícolas sobre o ambiente. Os impactos associados são de natureza biológica (os ecossistemas aquáticos são seriamente afetados por sedimentos e outros contaminantes associados) e recreacional (a turbidez da água afeta a pesca; o assoreamento limita as atividades como velejar ou nadar; o crescimento de plâncton diminui o prazer associado àquelas atividades, em rios e lagos poluídos). Outros impactos se associam com o aumento dos custos de tratamento da água e diminuição de sua disponibilidade, com o impedimento à navegação dos cursos d'água, e ainda com o aumento dos riscos de inundação (Clark II et al., 1985).

\subsection{Pesquisa em erosão}

\subsubsection{Estimativa da perda de solo ou modelagem da erosão}

A estimativa das perdas de solo por erosão em dado local, é o ponto de partida da investigação que tenha por objetivos diagnóstico e proposição de ações corretivas (Schertz, 1983). Há, no entanto, dificuldades para se avaliar de forma exata e precisa, a extensão, magnitude e taxas da erosão acelerada, bem como, os impactos econômicos e ambientais dela decorrentes (Lal, 1994). A pesquisa em erosão é cara e morosa (Lal, 1994). O processo erosivo varia no tempo e no espaço, e sua caracterização 
demanda o monitoramento em diferentes locais, no decorrer do ano, durante uma série de anos. A taxa de erosão em um dado local é determinada pelo modo particular com que os niveis das numerosas variáveis físicas e do manejo se combinam naquele local específico (Wischmeier \& Smith, 1978).

Para avaliar o impacto da erosão acelerada em dado local, é necessário que se disponha de alguma estimativa das taxas atuais de perda de solo (Schertz, 1983). Dentre um grande número de combinações possíveis, medições físicas da perda de solo para cada combinação dos diferentes níveis dos fatores que ocorrem sob condições de campo, não é uma tarefa exeqüível (Wischmeier \& Smith, 1978). Os modelos de previsão de perda de solo foram desenvolvidos para habilitar o planejador a estimar dados experimentais de erosão em locais e condições que não tenham sido diretamente representadas nas pesquisas (Wischmeier \& Smith, 1978). A modelagem da erosão é essencial ao planejamento conservacionista. A predição da erosão evoluiu da simples coleta de dados para comparação de práticas conservacionistas e do manejo, para modelos empíricos simples, para modelos empíricos complexos e, mais recentemente, para modelos determinísticos (McCool \& Renard, 1990).

A aplicação de modelos fornece resultados quantitativos, que permitem comparações objetivas, previsão e planejamento. Há diferentes tipos de modelos que estimam: 1) a quantidade de solo perdida via erosão hídrica; 2) a quantidade de sedimentos e nutrientes que atingem os cursos d'água; ou, 3) o teor de oxigênio dissolvido na água após uma descarga de sedimentos (McCool \& Renard, 1990). Tais modelos requerem um grande número de informações, algumas das quais obtidas somente através de experimentos de campo. Sem os dados necessários ou com escassez de dados, os modelos se tornam pouco confiáveis (Bouma, 1989).

O modelo empírico presentemente mais utilizado em todo mundo, corresponde à Equação Universal de Perda de Solo (Universal Soil Loss EquationUSLE), desenvolvida em 1954 no National Runoff and Soil Loss Data Center (Purdue University, USA), e posteriormente revisada por Wishmeier \& Smith $(1965 ; 1978)$. A USLE foi desenvolvida para estimar a perda média de solo de locais específicos, sob sistemas de cultivo e manejo também específicos, tendo por base os valores médios dos 
eventos de precipitação ocorridos, considerando uma série de observações de vinte anos ou mais (Wischmeier \& Smith, 1978). Consiste de um modelo multiplicativo, pelo qual a perda média anual de solo, expressa em massa por unidade de área, por tempo ( $\mathrm{A}$, em $\mathrm{Mg}$ ha ${ }^{-1}$ ano $\left.{ }^{-1}\right)$, é dada pelo produto de seis fatores determinantes, de acordo com a equação abaixo (Wischmeier \& Smith, 1978):

$$
A=R \text { K L S C P }
$$

Onde:

$\mathrm{R}=$ fator erosividade da precipitação e da enxurrada, expresso em $\mathrm{MJ} \mathrm{mm} \mathrm{ha}^{-1} \mathrm{~h}^{-1}$;

$\mathrm{K}=$ fator erodibilidade do solo, definido pela intensidade de erosão por unidade de índice de erosão da chuva, para um solo específico mantido continuamente sem cobertura, mas sofrendo as operações normais, em um declive de $9 \%$ e comprimento de

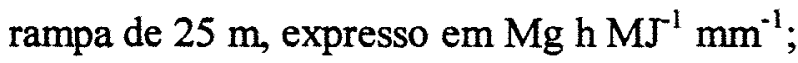

$L=$ fator comprimento da encosta, definido pela relação de perdas de solo entre uma encosta com um comprimento qualquer e uma encosta com $25 \mathrm{~m}$ de comprimento, para o mesmo solo e grau de inclinação, adimensional;

$\mathrm{S}=$ fator grau de declividade, definido pela relação de perdas de solo entre um terreno com um declive qualquer e um terreno com um declive de $9 \%$, para o mesmo solo e comprimento de rampa, adimensional;

$\mathrm{C}=$ fator de cobertura e manejo da cultura, definido pela relação de perdas de solo entre um terreno cultivado em dadas condições e um terreno mantido continuamente descoberto, em condições semelhantes àquelas em que 0 fator $\mathrm{K}$ é avaliado, adimensional;

$\mathrm{P}=$ fator prática de controle da erosão; definido pela relação entre as perdas de solo de um terreno cultivado com determinada prática e as perdas quando se planta morro abaixo, adimensional.

Os fatores $\mathrm{R}, \mathrm{K}, \mathrm{L}$ e $\mathrm{S}$ dependem das condições naturais do clima, do solo e do terreno, enquanto que os fatores $\mathrm{C}$ e $\mathrm{P}$ são antrópicos, ou relacionados com as formas de ocupação e uso das terras. Para produzir estimativas confiáveis, a aplicação do modelo requer que os fatores sejam caracterizados, ajustando-os à realidade local. 
Ao longo do tempo, foram desenvolvidas adaptações ao modelo original. Na Equação Universal de Perda de Solo Modificada, ou MUSLE, num esforço para estimar a produção de sedimentos em uma bacia hidrográfica, o fator R da USLE foi substituído por outro, baseado na taxa máxima e volume total da enxurrada para um evento em particular. O modelo CREAMS (Chemicals, Runoff, and Erosion from Agricultural Management Systems Model) concilia fatores da USLE com técnicas de previsão de enxurrada; estima a erosão linear e é aplicável a microbacias (McCool \& Renard, 1990). A partir de 1985, diversas agências federais e estaduais americanas iniciaram o projeto WEPP (Water Erosion Prediction Project), um modelo físico de simulação da erosão e da produção de sedimentos, que inclui componentes para gerar o clima e estimar a infiltração de água, o balanço hídrico, o desenvolvimento da cultura, a decomposição de resíduos, a enxurrada e a erosão. O modelo foi concebido para calcular variações temporais e espaciais de perda de solo em simulações contínuas, ou para um único evento (McCool \& Renard, 1990).

Apesar de ter sido desenvolvida para aplicação em glebas homogêneas, diversos autores tem usado a USLE para estimativa das perdas de solo em bacias hidrográficas (Silva \& Freire, 1986; Hession \& Shanholtz, 1988; Figueiredo, 1988; Donzeli et al., 1992; Hamlet, 1992; Mellerowicz et al., 1994; Jäger, 1994; Ranieri, 1996; Sparovek et al., 1997). A principal limitação de sua aplicação em bacias hidrográficas, relaciona-se com o fato de que o modelo assume o processo como sendo de caráter contínuo, e não contempla o fenômeno de deposição nas encostas. Ainda que apresente limitações, a USLE continua sendo muito usada em todo o mundo, por ser considerada um bom instrumento para previsão de perdas de solo por erosão entre-sulcos. Traz como vantagens, o fato de ser uma equação bastante conhecida e estudada, e que exige um número de informações relativamente pequeno, quando comparado ao exigido para aplicação de modelos empíricos mais complexos ou de modelos determinísticos (Jäger, 1994). Por essas razões, a USLE foi o modelo escolhido para estimativa da perda de solo na área da pesquisa. 


\subsubsection{Conceito de tolerância de perda de solo}

O solo é um recurso natural disponível apenas em uma extensão finita (FAO, 1974; Dregne, 1982; Skidmore, 1982; Schertz,1983). Na década de 30, nos Estados Unidos, a erosão acelerada do solo foi reconhecida como sendo o fator individual mais potente de deterioração das terras agrícolas (Bennett \& Lowdermilk, 1938). Por volta de 1940 , foi iniciado naquele país um movimento para estabelecer limites de perda de solo que dessem suporte aos planejadores conservacionistas (Schertz, 1983). A idéia era de que entre a perda excessiva de solo decorrente da erosão provocada pelo Homem e a perda inevitável oriunda da erosão geológica, deveria ser definida uma perda tolerável de solo.

O primeiro critério utilizado para estabelecer valores toleráveis de perda de solo, postulava seu embasamento no tempo de formação natural, ou taxa de formação dos solos. Sob condições naturais, diferentes pesquisadores estimaram que são necessários de 300 anos a 1000 anos, para se formarem $2,54 \mathrm{~cm}$ (ou 1 polegada) de solo, o que corresponderia à uma taxa de formação do solo, variando entre $0,0254 \mathrm{~mm}$ ano ${ }^{-1} \mathrm{e}$ $0,0850 \mathrm{~mm}$ ano $^{-1}$ (Schertz, 1983). Considerando um valor médio para a densidade do solo, em torno de $1,2 \mathrm{~g} \mathrm{~cm}^{-3}$, a esses valores corresponderiam taxas toleráveis de perda de solo entre $0,3 \mathrm{Mg} \mathrm{ha}^{-1}$ ano ${ }^{-1} \mathrm{e} 1,02 \mathrm{Mg} \mathrm{ha}^{-1}$ ano ${ }^{-1}$. Constatou-se, então, que as taxas estimadas de formação dos solos se referiam a valores extremamente baixos ou desprezíveis em termos reais (Friend, 1992), e que os dados disponíveis eram escassos e discutíveis, em função da complexidade de sua determinação (Alexander, 1988; Schertz, 1983). Além disso, limitar a perda de solo a uma taxa tão pequena, seria extremamente dificil, sem que ocorresse uma severa redução na produção (Schertz, 1983).

Tais constatações estimularam a busca por novos critérios para definição da tolerância. A primeira definição de tolerância de perda de solo, foi estabelecida ao final da década de 40 , e se referia a uma quantidade de solo que poderia ser perdida, sem que ocorresse decréscimo da fertilidade, mantendo-se, indefinidamente, a produtividade das culturas (Schertz, 1983). Em 1947, Browning e colaboradores, publicaram uma lista de solos, com os valores correspondentes de perda tolerável, fixando o valor máximo da perda tolerável em $11,2 \mathrm{Mg} \mathrm{ha}^{-1}$ ano ${ }^{-1}$. Os principais critérios em que se basearam para 
a definição dos valores foram: 1) a manutenção da produtividade por longo período de tempo, e 2) a prevenção da erosão linear. Esses pesquisadores consideraram que o tipo de solo influenciava o limite de tolerância, isto é, a erosão deveria ser considerada mais restritiva nos solos que apresentavam camadas de impedimento mecânico (como adensamentos), ou químico (como toxidez, muito baixa fertilidade, ou elevada acidez), relativamente a solos de textura média, uniformes em profundidade, e sem restrições de natureza química (Schertz, 1983).

A definição atual de tolerância de perda de solo, também referida por valor $T$, é essencialmente a mesma, e consta do trabalho de Wischmeier \& Smith (1978), que a descrevem como sendo "... a taxa máxima anual de erosão do solo que pode ocorrer e ainda permitir um alto nivel de produtividade das culturas, a ser obtido econômica e indefinidamente". Os critérios considerados no estabelecimento do valor $\mathrm{T}$ dos diferentes tipos de solos americanos, basearam-se na avaliação de: 1) erosão antecedente; 2) tipo de solo e profundidade atual; 3) ocorrência ou não de condições favoráveis dos atributos físicos, químicos e biológicos do solo, que afetam o desenvolvimento radicular; 4) prevenção de erosão linear; e, 5) prevenção da perda de matéria orgânica e dos nutrientes do solo. Baseando-se nesse conceito e critérios, o Serviço de Conservação de Solos dos Estados Unidos, definiu valores $T$ para a maior parte dos solos americanos, fixando-os na faixa entre 4,5 $\mathrm{Mg} \mathrm{ha}^{-1} \mathrm{ano}^{-1}$ e 11,2 $\mathrm{Mg} \mathrm{ha}^{-1}$ ano $^{-1}$ (Schmidt et al., 1979).

A proposição desses valores está relacionada com estimativas das taxas de formação do solo sob cultivo, que são muito mais elevadas do que em condições naturais, e com estimativas das taxas de formação do horizonte $A$, indicada pela acumulação de matéria orgânica, também muito mais rápidas, relativamente àquelas registradas para a formação da zona favorável de enraizamento, a partir do intemperismo do material de origem. Schertz (1983), apresentou estimativas de que sob cultivo, os mesmos $2,54 \mathrm{~cm}$ de solo se formariam em apenas 100 anos, ou à uma taxa de 0,254 $\mathrm{mm}$ ano ${ }^{-1}$, ou de 3 a 10 vezes superior do que aquela em condições naturais. À esta taxa de renovação corresponderia uma perda tolerável de no máximo $3,0 \mathrm{Mg} \mathrm{ha}^{-1}$ ano ${ }^{-1}$. Outras estimativas indicam que a acumulação da matéria orgânica, em um solo de 
textura média a moderadamente grosseira, pode ocorrer em menos de 30 anos. Por tais estimativas, a formação do horizonte A pode ocorrer à base de $2,54 \mathrm{~cm}$ a cada 30 anos, correspondente à uma taxa de $0,847 \mathrm{~mm}^{-1}$ ano ${ }^{-1}$ e a um valor da perda tolerável de 10,2 $\mathrm{Mg} \mathrm{ha}{ }^{-1}$ ano $^{-1}$ (Schertz, 1983).

A despeito destas taxas elevadas de renovação, entende-se que poderá haver perda considerável do potencial produtivo de muitos solos, que se tenham erodido por centenas de anos, aos níveis presentemente estabelecidos como sendo toleráveis (Schertz, 1983). À medida que material da superfície do solo é perdido por erosão, a renovação do horizonte $A$, dá-se às custas da transformação das camadas mais profundas do solo. Consequentemente, a profundidade total do volume de solo, favorável ao enraizamento, decresce e o solo vai se tornando progressivamente mais raso.

No entanto, ainda hoje, na interpretação das estimativas de erosão, prevalece o conceito clássico de tolerância. Baseados na definição de perda tolerável apresentada por Wischmeier \& Smith (1978), anteriormente citada, Bertoni \& Lombardi Neto (1990), definiram valores de tolerância para os solos do Estado de São Paulo, variando na faixa entre 4,5 e $15,0 \mathrm{Mg} \mathrm{ha}^{-1}$ ano $^{-1}$, de acordo com o tipo de solo. Solos rasos, como os solos litólicos e os litossolos, e solos com gradiente textural em profundidade, como os solos podzólicos, admitiriam perdas toleráveis muito menores, comparativamente aos latossolos, solos normalmente profundos, que se apresentam homogêneos em profundidade.

A interpretação desses autores é concordante com o senso comum de que na definição da tolerância, solos profundos, moderadamente permeáveis, de textura média e com características favoráveis ao desenvolvimento radicular, possuem tolerância de perda superior a solos rasos ou com limitações presentes no subsolo, como toxidez, muito baixa fertilidade, camadas adensadas ou contato lítico ou paralítico.

Pelo exposto é evidente que a tolerância de perda de solo é um parâmetro complexo, sujeito à controvérsia, dificil de ser estabelecido, e a respeito do qual não há um consenso generalizado. No conceito de tolerância como um valor (valor $T$ ), está embutida a finalidade de controle da erosão com vistas à manutenção da potencialidade do solo para uso agrícola. Para este fim, a potencialidade do solo pode ser restaurada, até 
um certo limite, por tecnologia de produção, o que mascara temporariamente o efeito da erosão. Neste caso, os valores de tolerância de perda de solo são muito mais elevados do que os que seriam recomendáveis, caso o objetivo fosse o controle da erosão, tendo em vista o uso sustentável para manutenção ou melhoria da qualidade do solo como um recurso natural, da qualidade dos recursos hídricos e da qualidade do ambiente.

Do ponto-de-vista do uso sustentável e da sustentabilidade, conceituar tolerância de perda de solo como uma função, e não como um valor fixo, parece um caminho mais promissor. Nesta linha, Stamey \& Smith (1964) propuseram uma equação para definição da tolerância, baseando-se em cinco pressupostos. A definição de tolerância deveria proporcionar 1) preservação permanente ou melhoria do solo como um recurso; 2) ser adaptável às taxas de erosão e de renovação de qualquer atributo do solo; 3) ser uma função da posição; 4) ser aplicável e 5) basear-se na pressuposição de que é tolerável utilizar o "excedente" de qualquer atributo do solo, considerados os requerimentos atuais ou previsíveis no futuro. Skidmore (1982), baseado nas pressuposições de Stamey \& Smith (1964), desenvolveu o conceito de tolerância como uma função da profundidade do solo, definindo como profundidade crítica o valor de 50 $\mathrm{cm}$ e adotando uma taxa média de renovação do solo de $0,2 \mathrm{~mm}$ ano ${ }^{-1}$. No Brasil, Sparovek e van Lier (1997), baseando-se nos trabalhos de Stamey \& Smith (1964) e Skidmore (1982), desenvolveram um conceito de tolerância de perda de solo como uma função do tempo, da posição, da profundidade do solo e das taxas de renovação e de erosão do solo. A pressuposição básica é de que taxas de erosão presentemente excessivas devem ser gradativamente reduzidas, até que uma condição limítrofe prédefinida seja atingida (uma profundidade mínima do solo, considerada crítica por exemplo), quando então as taxas de perda de solo devem se igualar à taxa média de formação. O tempo para que a condição de equilíbrio seja atingida (taxa de renovação $=$ taxa de erosão) passa a ser uma função do horizonte de planejamento definido para o controle da erosão na área de interesse. Esta proposição traz a vantagem de introduzir na análise o conceito de "horizonte de planejamento", ou tempo pré- definido para projeção das conseqüências da erosão, em contraposição ao termo "indefinidamente" associado ao conceito clássico de tolerância. Este enfoque permite associar à análise, intervalos de 
tempo considerados relevantes ou significativos, tendo em vista o plano de desenvolvimento projetado para determinada região.

Esta concepção funcional da tolerância, foi considerada no presente trabalho, para desenvolvimento de um índice quantitativo, como um novo critério de avaliação de impacto da erosão, tendo em vista as proposições levantadas nos trabalhos de Stamey \& Smith (1964), Skidmore (1982) e Sparovek \& van Lier (1997), combinadas ao conceito operacional de sustentabilidade, conforme apresentado por Hansen (1996) e Kruseman et al. (1996).

\subsubsection{Relação entre erosão e produção}

É de se esperar que reduções na espessura do solo devido à erosão condicionem queda de sua produtividade, uma vez que o suprimento de água disponível e de alguns nutrientes para as culturas, que é função da massa e do volume de solo, também diminuem (Alexander, 1988). Entretanto, os efeitos da erosão sobre a produtividade das culturas ainda não são bem conhecidos. Os resultados disponíveis se referem a estudos limitados relacionados a poucos tipos de solo (grande parte nos Estados Unidos), e conduzidos sob condições específicas de clima, uso e manejo (Pierce $\&$ Lal, 1994).

Quantificar o impacto da erosão sobre a produção das culturas é difícil porque a resposta das plantas à erosão é complexa e envolve a avaliação de uma série de interações entre a cultura e os atributos do solo, da paisagem, do clima predominante e do nível de manejo e de aplicação de insumos (Pierce \& Lal, 1994). O fato de que os efeitos da erosão são cumulativos e freqüentemente observáveis somente após transcorrido um longo período do início do processo, contribui para complicar a avaliação. Também é difícil separar os efeitos decorrentes da erosão de outros processos de degradação, tais como, compactação e salinização (Pierce \& Lal, 1994.). Clark II et al. (1985), afirmam que existe pouca informação sobre a extensão pela qual a erosão faz decrescer a produtividade. Estes mesmos autores relatam que, nos Estados Unidos, a produtividade média nacional continuou a crescer a uma taxa rápida, menos pela neutralização dos efeitos da erosão, e mais em função da introdução de novas variedades 
mais produtivas e aumento do uso de fertilizantes, bem como, pela utilização mais intensiva de outros insumos, como tração mecânica e água.

No Brasil, no município de Piracicaba, Sparovek et al. (1991), em um ensaio de erosão simulada para avaliação de seu efeito sobre a produtividade do milho em um solo podzólico vermelho-escuro latossólico endoálico, obtiveram que a remoção de terra provocou elevada queda no rendimento de grãos, mas que a adição de esterco associada à correção da acidez e à adubação mineral, trouxeram boa recuperação da produtividade, mesmo nos locais onde houve intensa remoção de terra e perda total do horizonte superficial do solo. Em trabalho mais recente, também no município de Piracicaba, em áreas muito erodidas que foram utilizadas com a cultura da cana-deaçúcar por cerca de 50 anos, Salviano, Vieira \& Sparovek (1998) caracterizaram que, em locais submetidos à erosão severa, com exposição da superficie do horizonte $\mathrm{C}$ de solos podzolizados, a produção da Crotalaria juncea $\mathrm{L}$. foi reduzida a $65 \%$ do valor máximo. Em contrapartida, encontraram que a produtividade não foi diretamente afetada pela erosão, nos locais onde os solos apresentavam $60 \mathrm{~cm}$ ou mais de profundidade. Apenas nos solos com menos de $20 \mathrm{~cm}$, foi caracterizada uma forte correlação com produtividades baixas ou muito baixas.

Já foi citado que a influência negativa da erosão sobre a potencialidade das terras é compensada, em certos casos, pelo avanço tecnológico dos meios e métodos da produção agrícola. $\mathrm{O}$ produtor compensa a perda da fertilidade natural pela aplicação de mais fertilizantes. Numa situação como esta, produzir se torna mais caro para o produtor, mas se a rentabilidade atingida com a produção ainda propicia um balanço economicamente favorável, o produtor continua a exploração sem adotar medidas mais enérgicas de conservação dos recursos da propriedade. No momento em que o desgaste se torna tão severo, que o solo perde substancialmente sua capacidade de reter água ou de sustentar o crescimento de plantas, a produtividade cai rápida e bruscamente, passando a inviabilizar economicamente a atividade (Clark II et al., 1985). Muito antes, porém, de ser atingida a inviabilidade econômica da atividade agrícola na propriedade, outros efeitos adversos da erosão acelerada podem estar ocorrendo no ambiente externo à área de produção. As consequiências indiretas da erosão podem apresentar impactos 
econômicos ainda maiores e mais sérios do que aqueles observados nas áreas de produção.

O conhecimento de como a erosão afeta a produção é chave para o desenvolvimento de práticas de restauração de solos erodidos. $\mathrm{O}$ consenso acerca da importância das questões relacionadas com a qualidade das águas superficiais e subterrâneas, com as mudanças climáticas e com a sustentabilidade em agricultura, aumentou o interesse da pesquisa em erosão do solo e do declínio da produção induzido pela erosão (Pierce \& Lal, 1994).

A relação direta entre erosão-produtividade agrícola não foi avaliada neste trabalho. Sua avaliação foi indireta, pela caracterização da degradação da qualidade do solo no tempo, partindo do pressuposto que isto condiciona o declínio progressivo do potencial agrícola das terras, até um limite insustentável, nem sempre facilmente perceptível.

\subsection{Ferramentas tecnológicas para um planejamento dinâmico}

\subsubsection{A tecnologia de Sistema de Informação Geográfica (SIG)}

Os estudos em planejamento agrícola requerem conhecimento acerca dos atributos e da distribuição espacial dos recursos naturais da região de interesse. Questões freqüentes a serem respondidas acerca dos recursos naturais, durante o processo de planejamento seriam (Burrough, 1987):

$\Rightarrow$ Onde está o objeto $A$ ?

$\Rightarrow$ Onde fica A em relação ao local B?

$\diamond$ Quantas ocorrências $A$ existem na distância $D$, entre $A$ e $B$ ?

$\Rightarrow$ Qual o valor da função $Z$ no ponto $X$ ? (Por exemplo, qual é o tipo de solo em X? ou como é a qualidade da água do lençol subterrâneo em $Y$ ?)

$\Rightarrow$ Quão grande é $B$ ? (área, perímetro, número de inclusões?)

$\triangleright$ Qual o resultado da interseção de vários tipos de dados espaciais? (onde ocorrem combinações particulares, como solos não salinos e áreas planas?)

$\Rightarrow$ Qual o caminho de menor custo, resistência ou distância indo de X para Y?

$\triangle O$ que há nos pontos $X 1, X 2, \ldots$ ? 
$\Rightarrow$ Quais objetos estão próximos de outros objetos exibindo certas combinações de atributos?

Quando os dados acerca dos recursos naturais estão disponíveis apenas na forma de mapas em papel, o planejador vê limitado o número de questões que podem ser respondidas rápida e efetivamente. Apesar de que ferramentas quantitativas para análises econômicas em desenvolvimento agrícola estejam em uso já há vários anos (Beek, 1978), até recentemente havia poucas mudanças na forma pela qual a informação sobre recursos naturais podia ser analisada. As descrições quantitativas eram obstruídas não apenas pelo volume de dados, mas também pela falta de observações quantitativas (Burrough, 1986). Além disso, não haviam métodos matemáticos apropriados para descrever a variação espacial quantitativamente. Segundo Burrough (1986), o desenvolvimento inicial de métodos matemáticos apropriados para solução de problemas espaciais ocorreu nas décadas de trinta e quarenta, paralelamente com o desenvolvimento dos métodos estatísticos. Um efetivo progresso, no entanto, era bloqueado na prática, pela falta de ferramentas de computação adequadas. Somente a partir de 1960, com a disponibilidade de computadores digitais, é que tanto os métodos conceituais para análises espaciais quanto a possibilidade real para mapeamento temático quantitativo e análise espacial puderam se desenvolver.

O desenvolvimento tecnológico hoje marca a evolução dos sensores remotos; métodos estatísticos envolvendo variáveis regionalizadas (ou geoestatística); análises de séries temporais; e métodos matemáticos para tratamentos das informações ambientais, como os modelos de simulação. O desenvolvimento ocorrido na tecnologia de computação, habilita os planejadores a analisar dados mapeados, e os unir com outras informações relevantes, de tal forma que as questões levantadas anteriormente podem agora ser respondidas rápida e facilmente. A nova tecnologia também permite a simulação de vários cenários econômicos, ou planos possíveis, antes que sejam implementados.

Uma das ferramentas tecnológicas que fornece novas oportunidades para um planejamento dinâmico, é referida por "Sistema de Informação Geográfica" (SIG). Os SIGs são o resultado do desenvolvimento em várias ciências relacionadas, incluindo 
computação gráfica, cartografia computadorizada, sensoriamento remoto, estatística espacial e tecnologia de banco de dados (Burrough, 1987). Um SIG é um conjunto de equipamentos e programas que permite (Burrough, 1986):

\section{$\Rightarrow$ Entrada e Edição}

$\triangle$ Armazenamento

$\Rightarrow$ Exame e Recuperação

$\diamond$ Transformação

$\triangle$ Análise

$\diamond$ Exibição e Impressão

... de dados de natureza espacial (explícita ou implícita)!

Uma formulação geral de um SIG, visualiza o espaço como estando coberto por um sistema de coordenadas cartesianas. Cada atributo distinto do espaço é descrito por um plano de informação (PI). Para cada ponto sobre a superfície, os valores na coluna do vetor do $P I$, definem os valores de todas as propriedades ou características da terra naquele ponto. Esta é forma pela qual muitos SIGs do tipo raster ou matricial trabalham (Burrough, 1989). A filosofia atual dos SIGs reconhece que dados espaciais consistem de entidades geográficas básicas, designadas por pontos, linhas ou áreas, que possuem atributos associados e informação sobre como eles podem ser conectados topologicamente (Burrough, 1987). Um SIG pode armazenar uma quantidade significativa de dados acerca da distribuição estática de atributos da terra, na forma de observações discretas ou como mapas temáticos. Em um SIG, pode-se também reunir e manipular dados variando em duas dimensões (superficie) e, menos comumente, variando em três dimensões (volume) (Burrough, 1987). Trabalhando com a tecnologia dos SIGs, deve-se considerar que os dados somente devem ser usados para sustentar decisões nos níveis de detalhe para os quais foram coletados. Não se pode obter resultados melhores do que os dados básicos, ou do que a qualidade dos modelos utilizados, permitem. A adequação dos tipos e intensidade dos dados coletados, com o nível de generalização e a escala do levantamento, é um compromisso que se impõe não apenas por limitações de tempo e dinheiro, mas também para atender ao objetivo pelo qual o levantamento foi executado (Burrough, 1987; 1989). 
A tecnologia dos SIG's apresenta uma série de vantagens para execução do processo de planejamento, dentre as quais se destacam:

$\Rightarrow$ Simulação de cenários econômicos e de planos de informação antes que ocorram ou sejam implementados;

$\Rightarrow$ Ágil monitoramento e atualização de dados e informações;

$\Rightarrow$ Planejamento dinâmico;

$\Rightarrow$ Após a implantação do banco inicial de dados, o custo de manutenção é relativamente baixo

\subsubsection{O método geoestatístico de análise da variabilidade espacial em solos}

Vários trabalhos têm mostrado que a variabilidade dos atributos do solo não é puramente aleatória, apresentando correlação ou dependência espacial (Vieira et al., 1981; Vieira et al., 1983). A caracterização da variabilidade espacial pode ser efetuada através do cálculo do autocorrelograma, do semivariograma, da análise espectral e da krigeagem (Vieira et al., 1981; Vieira et al., 1983; Libardi et al.,1986). A existência de dependência espacial, indicada pelo semivariograma, implica em vantagens na aplicação do método da krigeagem, para interpolação de medidas efetuadas no campo, sem tendência e com variância mínima (Vieira et al., 1997).

A hipótese de independência entre os valores de um atributo qualquer ocorrendo em uma área, somente pode ser verificada na prática, se a amostragem contiver informações geográficas relativas à sua posição, como suas coordenadas com referência a um sistema de eixos (Vieira, 1997). O fundamento da teoria geoestatística iniciou com os trabalhos de Matheron (Vieira et al.,1983), que constatou que observações efetuadas próximas umas das outras eram mais semelhantes entre si, quando comparadas com observações provenientes de locais mais distantes. Isto é, a variância é menor entre observações mais próximas, até um certo limite ou distância, a partir da qual as observações passam a ser independentes entre si. A variabilidade espacial dos atributos do solo, quando não considerada na análise, pode afetar os resultados da pesquisa (Vieira, 1997). Não existindo independência entre as amostras, é recomendado o uso de métodos geoestatísticos, para análise da estrutura da 
variabilidade espacial dos dados (Vieira et al., 1981; Vieira et al., 1983). A análise geoestatística se inicia pela verificação da existência de dependência espacial. As medições devem ocorrer dentro de um espaçamento que permita a análise da estrutura da variância dos dados. A existência de dependência espacial pode ser verificada pela construção do semivariograma. O semivariograma representa um gráfico de dispersão, tendo como valores do eixo $\mathrm{Y}$, as semivariâncias, e do eixo $\mathrm{X}$, as distâncias (Vieira, 1997). A semivariância pode ser calculada pela seguinte equação (Vieira et al., 1983; Vieira, 1997):

$$
\gamma(\mathbf{h})=(\mathbf{1} / 2 \mathrm{~N}(\mathrm{~h})) \sum\left[\mathrm{Z}\left(\mathrm{x}_{\mathrm{i}}\right)-\mathrm{Z}\left(\mathrm{x}_{\mathbf{i}}+\mathbf{h}\right)\right]^{2}
$$

Onde:

$$
i=1
$$

$\gamma(\mathbf{h})=$ semivariância;

$\mathbf{N}(\mathbf{h})=$ número de pares de valores medidos;

$\mathbf{Z}\left(\mathbf{x}_{\mathbf{i}}\right), \mathbf{Z}\left(\mathbf{x}_{\mathbf{i}}+\mathbf{h}\right)=$ par de valores da variável $Z$, em $\mathbf{x}_{\mathbf{i}}$ e em $\mathbf{x}_{\mathbf{i}}+\mathbf{h}$, ou valores $Z$ separados pelo vetor $h$.

Dependência espacial significa autocorrelação, ou seja, o valor em qualquer ponto, depende de algum modo, do valor do ponto vizinho. Essa característica é expressa na Equação 2 pela expressão $\left[\mathbf{Z}\left(\mathbf{x}_{\mathbf{i}}\right)-\mathbf{Z}\left(\mathbf{x}_{\mathbf{i}}+\mathbf{h}\right)\right]^{2}$. Para propriedades espacialmente dependentes, espera-se que a diferença entre os valores $\left[\mathbf{Z}\left(\mathbf{x}_{\mathbf{i}}\right)-\mathbf{Z}\left(\mathbf{x}_{\mathbf{i}}+\mathbf{h}\right)\right]^{2}$, em média, seja crescente com a distância até um determinado ponto, a partir do qual se estabiliza num valor denominado patamar $\left(\mathbf{C}_{\mathbf{o}}+\mathbf{C}_{\mathbf{1}}\right)$, aproximadamente igual à variância dos dados (Vieira, 1997). A distância na qual a semivariância se estabiliza é denominada alcance (a), e representa o raio de um círculo, dentro do qual os valores são tão parecidos uns com os outros que se tornam correlacionados. $\mathrm{O}$ valor da variância na interseção do eixo $\mathrm{Y}$, é denominado de efeito pepita $\left(\mathbf{C}_{\mathbf{0}}\right)$, e representa a variabilidade do atributo em estudo, em espaçamentos menores do que o amostrado. Quanto maior o efeito pepita, mais fraca é a dependência espacial do atributo em questão (Vieira et al., 1983). Com os parâmetros efeito pepita $\left(C_{0}\right)$, patamar $\left(C_{0}+C_{1}\right)$ e alcance $(a)$, faz-se o ajuste de equações ao semivariograma. 
Um semivariograma escalonado é obtido dividindo a semivariância pela variância dos dados. Este procedimento permite a comparação de semivariogramas de atributos distintos (Vieira et al. 1991; Vieira, 1997). Caracterizada a dependência espacial, os valores vizinhos serão tão semelhantes que há possibilidade de estimar valores para qualquer local onde o atributo não foi medido, usando tal dependência. A estimativa $Z^{*}$ na posição $x_{0}$ pode ser obtida pela equação (3) (Vieira, 1997):

$$
\mathbf{Z}^{\star}\left(\mathbf{x}_{\mathbf{0}}\right)=\sum_{\mathrm{i}=1}^{\mathrm{N}} \lambda_{\mathbf{i}} \mathbf{Z}\left(\mathbf{x}_{\mathbf{i}}\right)
$$

Sendo:

$\mathbf{Z}\left(\mathbf{x}_{\mathbf{i}}\right)$ é o valor medido na posição $\mathrm{x}_{\mathrm{i}}$;

$\lambda_{i}$ é o peso associado ao valor medido na posição $x_{i}$;

$\mathbf{N}$ é o número de pares medidos usados na estimativa do valor $Z^{*}\left(x_{0}\right)$.

Um bom método de estimativa não deve superestimar nem subestimar valores (sem viés), e os desvios em relação aos valores conhecidos devem ser mínimos (variância minima). Impondo-se as condições de estimativa sem viés e variância mínima à equação (3) acima, obtém-se o sistema de equações da krigeagem (4):

$$
\begin{aligned}
& \sum_{j=1}^{N} \lambda_{j} \gamma\left(x_{i}, x_{j}\right)+\mu=\gamma\left(x_{i}, x_{0}\right), j=1, N \\
& \sum_{j=1}^{N} \lambda_{j}=1
\end{aligned}
$$

Onde:

$\gamma\left(\mathbf{x}_{\mathbf{i}}, \mathbf{x}_{\mathbf{j}}\right)$ é a semivariância estimada pelo modelo ajustado ao semivariograma, correspondente à distância entre os pontos localizados nas posições $\mathbf{x}_{\mathbf{i}} \mathbf{e} \mathbf{x}_{\mathbf{j}}$;

$\gamma\left(\mathbf{x}_{\mathbf{i}}, \mathbf{x}_{\mathbf{0}}\right)$ é a semivariância correspondente à distância entre os pontos localizados nas posições $\mathbf{x}_{\mathbf{i}}$ e $\mathbf{x}_{\mathbf{0}}$ (Vieira, 1997).

A solução do sistema de equações da krigeagem (4), gera $\mathbf{N}$ valores de pesos $\lambda$ e um valor do multiplicador de Lagrange, $\mu$, associado com a minimização da variância. 
Substituindo-se os valores dos pesos, $\lambda_{\mathbf{i}}$, na equação (3), pode-se estimar os valores para toda posição $\mathbf{x}_{\mathbf{0}}$ no espaço amostrado. Com os valores interpolados, pode-se construir mapas de isolinhas ou mapas tridimensionais, para exame e interpretação da variabilidade (Vieira, 1997).

O método de análise geoestatística foi utilizado na pesquisa para interpolação dos parâmetros erodibilidade e profundidade do solum na bacia. $O$ procedimento detalhado é apresentado no capítulo seguinte (em Material e Métodos, Seção 3.7.2).

\subsection{Considerações sobre a proposição da pesquisa}

A revisão de literatura mostrou que o estudo da erosão, embora relativamente recente, já foi contemplado com inúmeros trabalhos. $\mathrm{A}$ despeito da literatura farta, e da realização de alguns simpósios, visando reunir o conhecimento disponível e propor normas de desenvolvimento de trabalhos futuros, a caracterização da erosão e o estudo de impacto, permanece um assunto vasto, complexo, e com disponibilidade limitada de dados confiáveis, especialmente para a região tropical. Tais fatos estimularam para a proposição de uma nova maneira de abordagem do problema. Esse reconhecimento da relevância dos problemas ambientais associados com a erosão acelerada de solos agrícolas, e a carência de critérios quantitativos de avaliação, com valor prognóstico, incentivou a busca pelo estabelecimento de um novo critério que atendesse às necessidades dos trabalhos em planejamento. 


\section{MATERIAL E MÉTODOS}

\section{1 Área da pesquisa}

A área da pesquisa corresponde à maior parte da Bacia Hidrográfica do Ribeirão do Ceveiro (BHC), incluindo a represa principal, a jusante. Pertencente à Bacia do Rio Piracicaba, a BHC está situada no município de Piracicaba, no Estado de São Paulo, entre as coordenadas geográficas $22^{\circ} 36^{\prime} 38^{\prime \prime}$ e $22^{\circ} 41^{\prime} 29^{\prime \prime}$, de latitude sul, e $47^{\circ} 42^{\prime}$ $16^{\prime \prime}$ e $47^{\circ} 47^{\prime} 01^{\prime \prime}$, de longitude oeste (Figura 1).

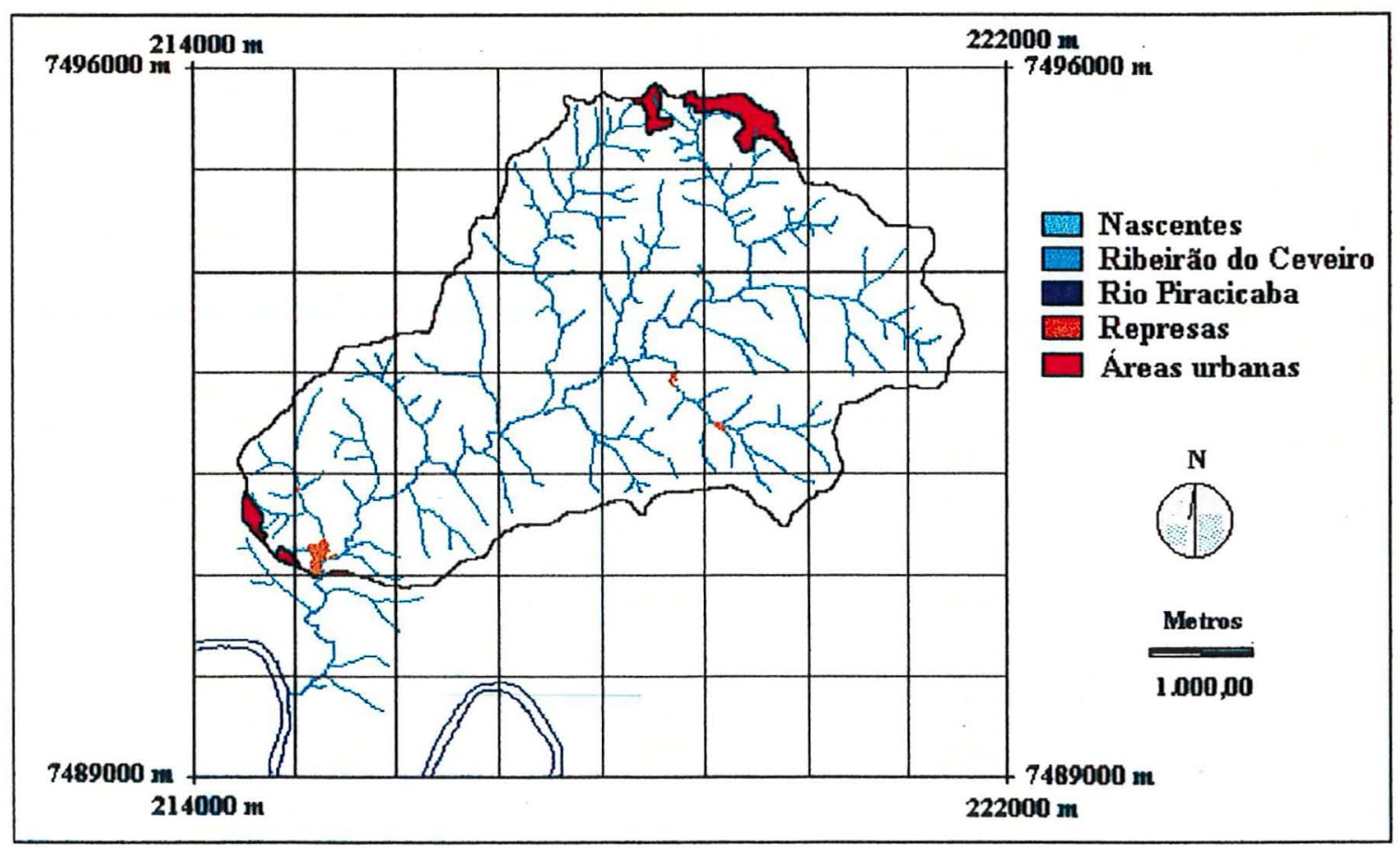

Figura 1-Bacia Hidrográfica do Ribeirão do Ceveiro, município de Piracicaba (SP): limites, áreas urbanas e hidrografia.

A área da BHC, representada na Figura 1, perfaz 1.990,40 ha, incluindo parte das áreas urbanas do distrito de Ártemis (a jusante) e da vila de Santana (a 
montante) e as áreas de represa. A área efetivamente avaliada na pesquisa, foi de $1.945,72 \mathrm{ha}$, descontando-se as áreas urbanas $(39,16 \mathrm{ha})$ e as de represa $(5,52 \mathrm{ha})$. A bacia do Ceveiro já foi objeto de estudos anteriores, geradores de dados e informações preliminares, que foram utilizados no presente estudo (Sparovek, 1991).

O levantamento do uso das terras da BHC, realizado por Fiorio (1998), a partir de fotografias aéreas (P\&B, escala 1:25.000, vôo: BASE, ano: 1995), mostra a predominância da cultura da cana-de-açúcar, que se distribui por cerca de 1.319 ha, ou em $67,8 \%$ da área avaliada. Nos 626 ha restantes, a ocupação principal se dá com usos menos intensivos, representados por pastagens, reflorestamento e matas. A ocupação com culturas anuais é muito restrita, representando menos de $0,2 \%$ da área total avaliada. A Tabela 1 relaciona as categorias de uso das terras da bacia e as respectivas áreas de ocorrência, em hectares e porcentagem.

\begin{tabular}{ccc} 
Tabela 1- Uso das terras na bacia hidrográfica do \\
\multicolumn{3}{c}{$\begin{array}{l}\text { Ribeirão do Ceveiro: categorias e áreas de } \\
\text { ocorrência }\end{array}$} \\
\hline Uso & ha & Área \\
\hline & 1319,64 & 66,30 \\
\hline Cana-de-açúcar & 96,40 & 4,84 \\
Pastagem Plantada & 181,24 & 9,11 \\
Pastagem Natural & 2,96 & 0,15 \\
Cultura Anual & 120,12 & 6,04 \\
Reflorestamento & 134,08 & 6,74 \\
Mata & 91,28 & 4,59 \\
Vegetação Ciliar & 39,16 & 1,97 \\
Area Urbana & 5,52 & 0,28 \\
Represas & 1990,40 & 100,00 \\
Total &
\end{tabular}

Fonte: Fiorio, 1998.

\subsection{Materiais cartográficos básicos}

O trabalho foi efetuado tendo por base cartográfica, cartas topográficas na escala 1:10.000, do Plano Cartográfico do Estado de São Paulo, da Secretaria de Economia e Planejamento, do Governo do Estado de São Paulo. A área da BHC está contida na articulação de quatro cartas topográficas:

- Estância Lago Azul (SF. 23- Y- A- IV- 1- SE -B), articulação 070/ 087; 
- Ártemis (SF. 23- Y- A- IV- 1- SE -D), articulação 071/ 087;

- Córrego das Ondas (SF. 23- Y- A- IV-2- SO- A), articulação 070/ 088;

- Vila Olímpia (SF. 23- Y- A-IV-2-NO- E), articulação 069/ 088.

A partir da informação das cartas topográficas 1:10.000, foram extraídos os seguintes mapas básicos:

- Contorno da BHC;

- Mapa de Curvas de Nível $(E V=5 \mathrm{~m})$;

- Hidrografia.

\subsection{Implantação do banco de dados espaciais}

Os mapas de contorno da bacia, curvas de nível, hidrografia, e ainda o mapa do uso das terras, foram digitalizados utilizando o programa gráfico AUTOCAD 12 (versão DOS). Os arquivos digitais, em formato.$d x f$, foram exportados para o Sistema de Informação Geográfica (IDRISI for Windows, v. 2.0; Eastman, 1997), compondo os quatro primeiros planos de informação $(P I)$ do banco de dados espaciais da pesquisa.

No IDRISI, um sistema de informação geográfica (SIG) do tipo raster, os arquivos . dxf foram vetorizados e, a seguir, convertidos em arquivos imagem (extensão .img). No processo, um arquivo documento associado (extensão .doc) é necessariamente criado. No arquivo documento são definidos os principais atributos da imagem, ou de qualquer outro tipo de arquivo dentro do SIG. Do arquivo documento, constam informações acerca de: a) localização e limites, definidos pelo sistema de referência, unidades e valores mínimos e máximos das coordenadas $\mathrm{X}$ e $\mathrm{Y}$; b) tamanho do arquivo, definido pelo número de linhas e de colunas, que por sua vez definem o tamanho do píxel, ou tamanho da célula básica em que a informação é armazenada no sistema; c) tipo do dado (byte, inteiro ou real) e tipo do arquivo (binário, ASCII ou compactado); d) outras informações: título, legenda, valores mínimo e máximo, entre outras. O que possibilita combinação e execução de operações entre imagens, é a compatibilidade entre seus atributos, conforme definidos no arquivo documento. Nos arquivos do projeto Ceveiro, foi usado o sistema de coordenadas Universal Transversa 
de Mercator, ou coordenadas UTM, que define sistema de referência plano e unidades em metros. Todos os arquivos do Ceveiro foram construídos com píxels de $20 \mathrm{~m} \times 20 \mathrm{~m}$, nas direções $\mathrm{X}$ e $\mathrm{Y}$, compondo arquivos de 400 colunas por 350 linhas. $\mathrm{O}$ tamanho do pixel $(20 \mathrm{~m} \times 20 \mathrm{~m})$ foi escolhido tendo em vista compatibilizar o nível de detalhe da informação original (mapas básicos na escala de 1: 10.000) e a obtenção de arquivos não muito grandes, para não sobrecarregar o sistema computacional.

\subsection{Plano amostral}

O trabalho no campo visou a coleta de amostras de solo, para sua caracterização física e química, e o registro da espessura do solum. Foram coletadas amostras deformadas e indeformadas, por tradagens e em trincheiras.

Nas coletas efetuadas com o trado, os solos foram amostrados até 120 $\mathrm{cm}$, profundidade normalmente suficiente para atingir o horizonte $\mathrm{C}, \mathrm{CR}$ ou $\mathrm{R}$. Foram amostradas seis camadas: $0-20 \mathrm{~cm} ; 20 \mathrm{~cm}-40 \mathrm{~cm} ; 40 \mathrm{~cm}-60 \mathrm{~cm} ; 60 \mathrm{~cm}-80 \mathrm{~cm} ; 80$ $\mathrm{cm}-100 \mathrm{~cm} ; 100 \mathrm{~cm}-120 \mathrm{~cm}$. Nos locais com solos mais profundos, as tradagens foram além dos $120 \mathrm{~cm}$, para definição da espessura do solum ou soma das espessuras dos horizontes $(\mathrm{A}+\mathrm{B})$. Foram amostrados 132 pontos, espalhados por toda a área da bacia, e mais 59 pontos, concentrados em uma sub-bacia, espaçados regularmente de 20 $\mathrm{m} \times 20 \mathrm{~m}$, formando uma malha amostral ou grid. Em torno desse grid, foram concentrados mais 20 pontos de amostragem, a espaços irregulares. Ao todo, foram amostrados, por tradagem, 221 pontos em toda a bacia.

A caracterização de perfis representativos dos solos da bacia foi obtida pela amostragem em trincheiras. Foram abertas 30 trincheiras, até $120 \mathrm{~cm} \mathrm{de}$ profundidade, em toposseqüências selecionadas, distribuídas pela área da bacia. Também aqui, quando o horizonte $\mathrm{C}, \mathrm{CR}$ ou $\mathrm{R}$ não foi encontrado até $120 \mathrm{~cm}$, foi tradado o fundo da trincheira, para definição da espessura do solum. Foram efetuadas as descrições morfológicas dos perfis e coletadas amostras deformadas, por horizonte pedogenético, para caracterização física e química. Nas trincheiras, também foram coletadas amostras indeformadas, em anel do tipo Kopeck, com volume aproximado de $100 \mathrm{~cm}^{3}$, extraídas com amostrador do tipo Uhland, para caracterização da densidade do 
solo. As amostras indeformadas foram extraídas nas profundidades de $10 \mathrm{~cm}, 30 \mathrm{~cm}, 50$ $\mathrm{cm}, 70 \mathrm{~cm}, 90 \mathrm{~cm}$ e $110 \mathrm{~cm}$.

Em toda a bacia, entre tradagens e trincheiras, foram amostrados 251 pontos, cuja ilustração consta da Figura 2. A Figura 3 mostra o grid (ou malha regular) em detalhe.

\subsubsection{Geo-referenciamento dos locais de amostragem}

Os 251 pontos de amostragem, foram geo-referenciados utilizando a tecnologia de Sistema de Posicionamento Global ou GPS (Global Positioning System), com correção diferencial por pós-processamento. Foram utilizados dois equipamentos manuais, modelo Geo Explorer II, da Trimble. Um equipamento permaneceu estacionário, ligado a uma antena instalada numa posição conhecida (Latitude: $22^{\circ} 42^{\prime}$ 29,5309" S; Longitude: $47^{\circ} 37^{\prime} 53,7822^{\prime \prime}$ O), que funcionou como estação base. O outro equipamento, móvel, foi levado ao campo para tomada das posições dos pontos de amostragem. A posição de campo foi posteriormente corrigida em relação aos registros dos arquivos da estação base, através do programa Pathfinder Office da Trimble, que opera a correção diferencial dos dados, tornando os erros de localização inferiores a 5 m. A localização dos pontos foi obtida no sistema de coordenadas UTM, Zona 2 (Referência: UTM Datum South America 1969-Brazil).

\subsection{Métodos analíticos}

As amostras de solo foram analisadas no Laboratório de Física do Solo e no Laboratório de Química e Fertilidade do Solo, ambos do Departamento de Solos e Nutrição de Plantas, da ESALQ/ USP.

Para execução da análise granulométrica, as amostras de solo foram secas ao ar e passadas por peneira ASTM n. ${ }^{\circ} 10$ (malha de $2 \mathrm{~mm}$ ), para obtenção da terra fina seca ao ar (TFSA). As amostras de TFSA foram dispersas utilizando solução $0,1 \mathrm{~N}$ de $\mathrm{NaOH}$ e hexametafosfato de sódio, e agitação lenta em agitador mecânico horizontal. A fração areia foi separada por tamisagem em cinco classes de tamanho: areia muito grossa $(2,0 \mathrm{~mm}-1,0 \mathrm{~mm})$, areia grossa $(1,0 \mathrm{~mm}-0,5 \mathrm{~mm})$, areia média $(0,5 \mathrm{~mm}-0,25$ 


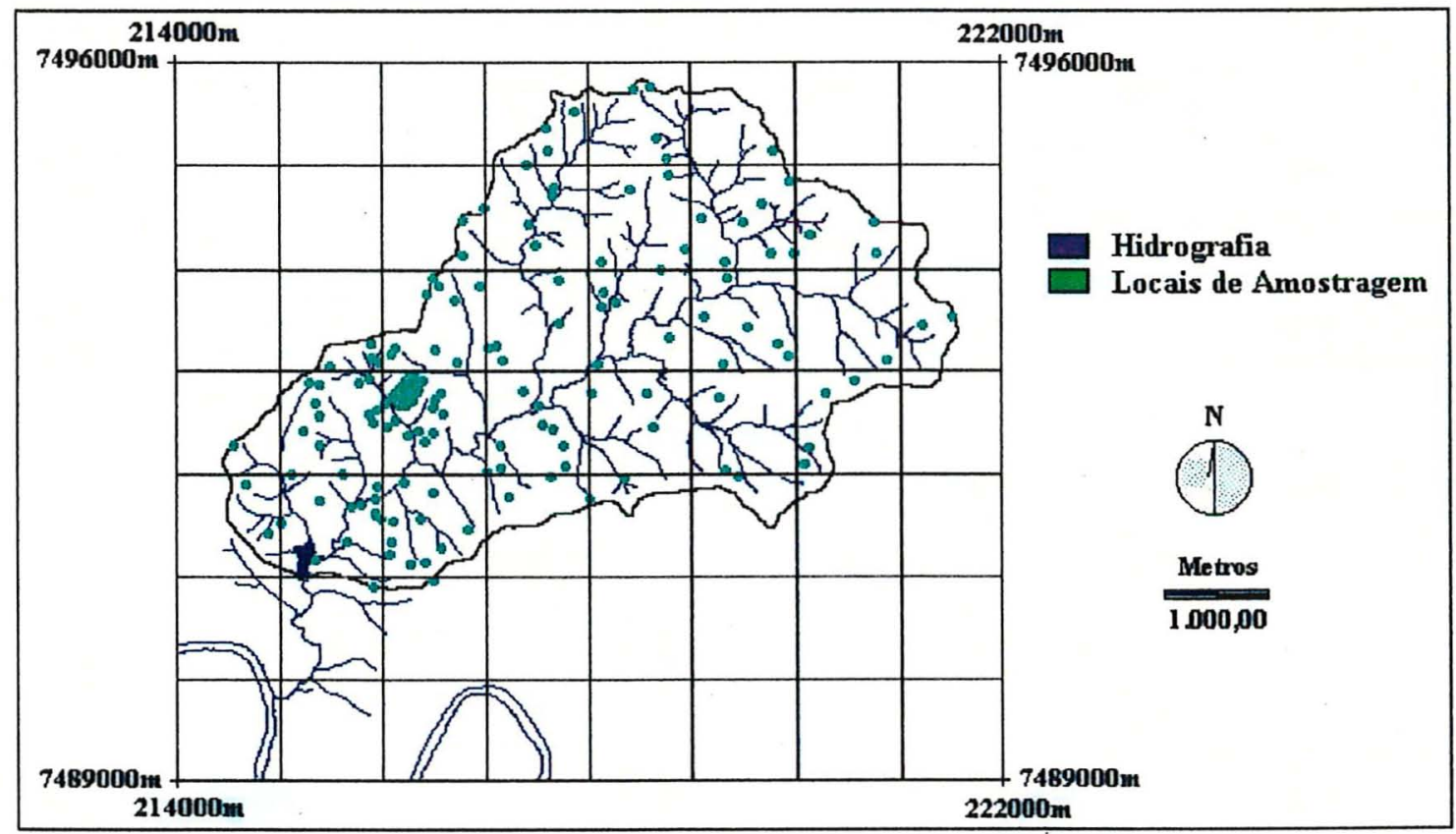

Figura 2- Locais de amostragem dos solos da bacia hidrográfica do Ceveiro.

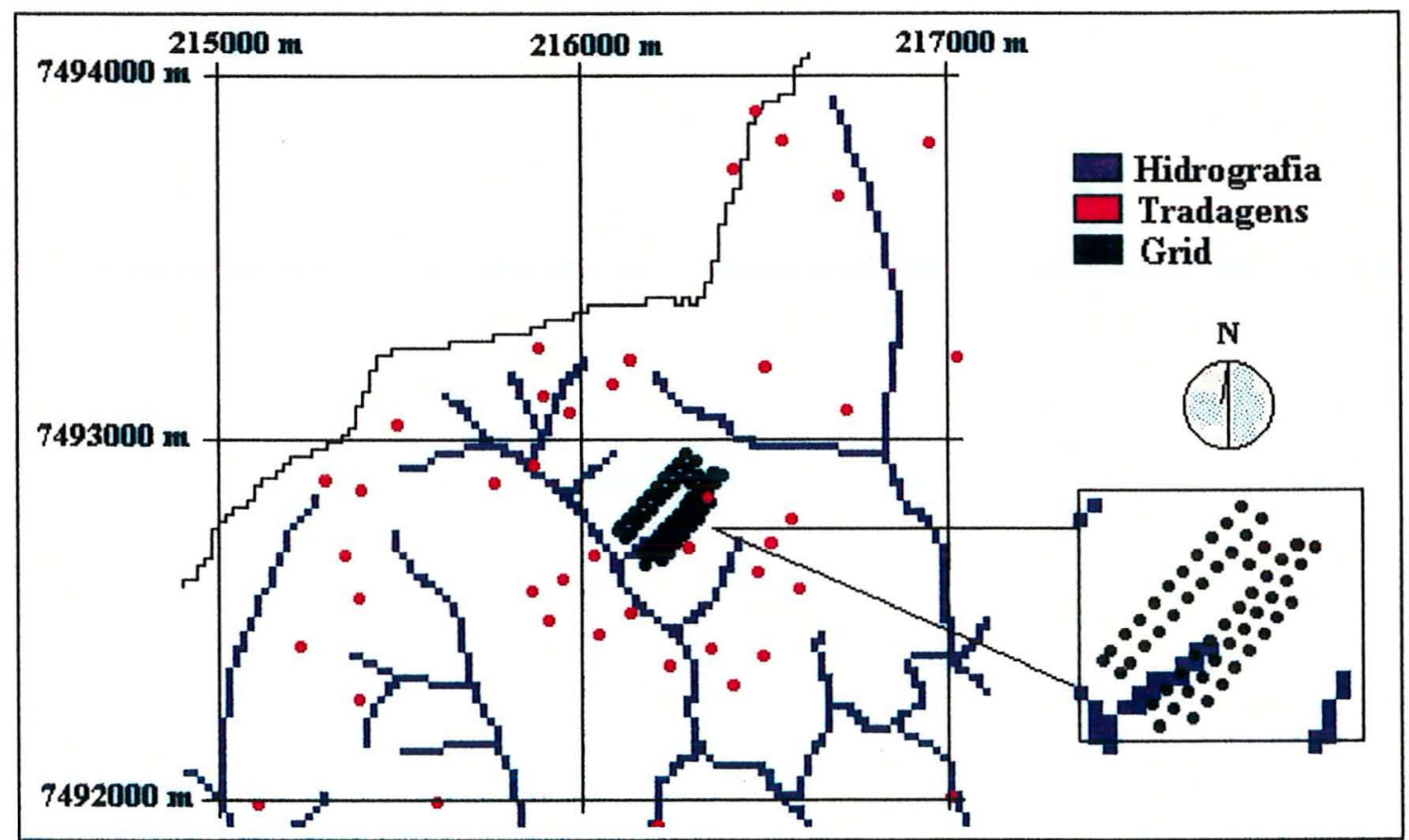

Figura 3- Detalhe da malha regular de amostragem de solos, ou grid, da bacia hidrográfica do Ceveiro. 
$\mathrm{mm})$; areia fina $(0,25 \mathrm{~mm}-0,10 \mathrm{~mm})$, areia muito fina $(0,10 \mathrm{~mm}-0,05 \mathrm{~mm})$. As frações silte e argila foram obtidas pelo Método de Boyoucos ou do Hidrômetro, conforme descrito em Kiehl (1979). O teor de argila na amostra de solo indica a classe textural, sendo definidas cinco classes texturais: arenosa ( $<14 \%$ de argila); média arenosa $(14 \%$ - $24 \%$ de argila); média argilosa (25\% - $34 \%$ de argila); argilosa (35\% - $59 \%$ de argila); muito argilosa (> $60 \%$ de argila).

As análises químicas foram efetuadas seguindo os métodos descritos em Raij et al. (1987). Foram determinados os valores do $\mathrm{pH}$ em água e em $\mathrm{CaCl}_{2} \mathbf{0 , 0 1}$ M; da matéria orgânica do solo, pelo Método Walkley-Black; do fósforo disponível e dos cátions básicos trocáveis, $\mathrm{K}^{+}, \mathrm{Ca}^{++}, \mathrm{Mg}^{++}$, pelo método da resina; e do alumínio trocável, por extração com $\mathrm{KCl} 1 \mathrm{~N}$. Foram obtidos por cálculo, a soma de bases trocáveis, a capacidade de troca de cátions, a saturação por bases e a saturação por alumínio trocável.

Para obtenção da densidade do solo, após a extração da amostra indeformada, o solo contido no anel foi liberado, e o número do anel anotado. A partir da massa do solo seca em estufa (a $110^{\circ} \mathrm{C}$, por $48 \mathrm{~h}$ ), e do volume do anel (igual ao volume do solo), foi calculada a densidade do solo por camada amostrada, segundo a equação:

$$
d_{\text {solo }}=m_{\text {se }} V^{-1}
$$

Sendo:

$\mathrm{d}_{\text {solo }}=$ densidade do solo, em $\mathrm{g} \mathrm{cm}^{-3}$

$\mathrm{m}_{\mathrm{se}}=$ massa do solo seco em estufa, em $g$

$\mathrm{V}=$ volume do solo, em $\mathrm{cm}^{3}$

Tais procedimentos estão descritos em Kiehl (1979). Com os valores da densidade do solo obtidos por camada para os 30 perfis, foi calculado um valor médio da densidade do solo para toda a bacia. Optou-se pela coleta em camadas a profundidades fixas, e não uma amostra por horizonte pedogenético (espessura variável), para que na generalização do valor da densidade, espessuras iguais de solos distintos, fossem 
representadas com igual número de amostras.

\subsection{Estimativa das perdas de solo: ajuste dos fatores do modelo USLE}

Para estimativa das taxas atuais de perda de solo na bacia, foi utilizado o modelo USLE (Wischmeier \& Smith, 1978), apresentado na Revisão de Literatura (Seção 2.4.1). Para aplicação da USLE na bacia do Ceveiro, os fatores do modelo foram ajustados às condições locais, utilizando o banco de dados gerado para a bacia, contendo informações sobre clima, solo, relevo e uso da terra. Aos dados básicos foram aplicados modelos e relações desenvolvidas por pesquisadores brasileiros, para adaptação dos fatores às nossas condições. A metodologia de obtenção de cada um dos fatores é pormenorizada a seguir.

\subsubsection{Fator $\mathbf{R}$ ou fator erosividade da precipitação e da enxurrada}

Os dados da Tabela 2 representam um ano "normal" em Piracicaba. Da Tabela 2 constam os valores médios mensais da temperatura média $\left(T_{\text {méd. }}\right.$, em $\left.{ }^{\circ} \mathrm{C}\right)$, da precipitação (P, em mm) e da evapotranspiração potencial (ETP, em mm), calculados para Piracicaba, a partir de uma série de 80 anos de registros do Posto Meteorológico da

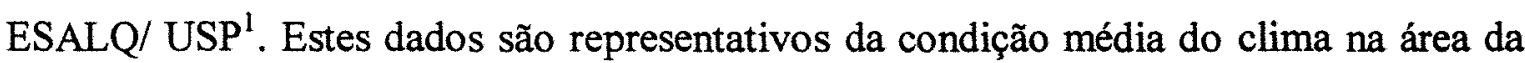
pesquisa.

$\mathrm{O}$ cálculo da erosividade da chuva para o Ceveiro, ou do fator $\mathrm{R}$, expresso em MJ mm ha ${ }^{-1} \mathrm{~h}^{-1}$, foi obtido aplicando aos dados da Tabela 2, a relação desenvolvida por Lombardi Neto \& Moldenhauer (1980), dada a seguir:

$$
E I_{i}=67,355\left(r_{i}^{2} / P_{i}\right){ }^{0,85}
$$

Sendo:

$\mathrm{EI}_{\mathrm{i}}=$ média mensal do índice de erosão, no iésimo mês $\left(\mathrm{MJ} \mathrm{ha}^{-1} \mathrm{~mm}^{-1}\right)$;

$\mathrm{r}_{i}=$ precipitação média mensal, em $m m$, no iésimo mês;

$\mathrm{P}_{i}=$ precipitação média anual, em $\mathrm{mm}$;

$(1 \leq i \leq 12)$

Foram calculados os índices mensais de erosão, de janeiro a dezembro

\footnotetext{
${ }^{1}$ Dados obtidos junto ao Departamento de Ciências Exatas da ESALQ/ USP.
} 
(EI i ) pela expressão 3, e o fator R da USLE foi obtido pela somatória dos valores mensais.

Tabela 2- Caracterização meteorológica de um ano normal em Piracicaba: valores médios mensais de uma série de 80 anos.

\begin{tabular}{|c|c|c|c|c|}
\hline Mês & $\mathbf{N}$ Dias & $\begin{array}{c}\mathbf{T}_{\text {Mod. }} \\
{ }^{\circ} \mathrm{C}\end{array}$ & $\mathbf{P}$ & ETP \\
\hline Janeiro & 30 & 24,4 & 220 & 124,58 \\
\hline Fevereiro & 28 & 24,6 & 184 & 113,29 \\
\hline Março & 31 & 24,0 & 137 & 112,59 \\
\hline Abril & 30 & 21,8 & 65 & 82,04 \\
\hline Maio & 31 & 19,1 & 52 & 58,85 \\
\hline Junho & 30 & 17,6 & 46 & 45,44 \\
\hline Julho & 31 & 17,3 & 28 & 45,45 \\
\hline Agosto & 31 & 19,1 & 29 & 59,91 \\
\hline Setembro & 30 & 20,7 & 60 & 74,85 \\
\hline Outubro & 31 & 22,2 & 107 & 96,24 \\
\hline Novembro & 30 & 23,1 & 131 & 107,45 \\
\hline Dezembro & 31 & 23,8 & 198 & 122,09 \\
\hline
\end{tabular}

Fonte: Departamento de Ciências Exatas/ ESALQ/ USP, 1997. Códigos: $\mathrm{N}^{0}$ Dias, número de dias no mês, $T_{\text {Medb }}$ temperatura média, em graus centígrados; $P$, precipitação pluviométrica; ETP, evapotranspiração potencial, ambos em milímetros.

\subsubsection{Fator $\mathrm{K}$ ou fator erodibilidade do solo}

A erodibilidade dos solos do Ceveiro, ou fator $\mathrm{K}$, foi estimada para cada um dos 251 pontos amostrados, empregando o modelo selecionado por Denardin (1990), para solos do Brasil e dos Estados Unidos. A equação representativa é a seguinte:

$$
K=0,00000748 X_{1}+0,00448059 X_{2}-0,0631175 X_{3}+0,01039567 X_{4}
$$

Sendo:

$\mathrm{K}=$ erodibilidade estimada pelo modelo de Denardin (1990), expressa em $\mathrm{Mg} \mathrm{h} \mathrm{Mj}^{-1}$ $\mathrm{mm}^{-1}$;

$\mathbf{X}_{\mathbf{1}}=$ variável [("Novo" Silte + "Nova" Areia) * "Novo" Silte], sendo:

"novo" silte $=$ silte + areia muito fina

"nova" areia $=$ areia muito grossa + areia grossa + areia média + areia fina

$\mathbf{X}_{2}=$ variável permeabilidade do solo, de acordo com a classificação: (1) Rápida; (2) Moderada a Rápida; (3) Moderada; (4) Lenta a Moderada; (5) Lenta; (6) Muito Lenta.

Obs.: A classe de permeabilidade do solo foi atribuída, para cada ponto amostrado, a 
partir da avaliação qualitativa do conjunto de atributos: granulometria do solo; homogeneidade do perfil; ocorrência de gradiente textural do horizonte A para o B; profundidade do solo; ocorrência de contato lítico ou paralítico; uso da terra; e presença de mosqueados, pedregosidade e/ ou rochosidade. Perfis pouco homogêneos, com presença de gradiente textural, horizonte B argiloso, contato lítico ou paralítico com material pouco permeável, pequena profundidade até a camada restritiva e presença de mosqueados, foram considerados atributos indicativos de restrição da permeabilidade. $\mathrm{O}$ grau de restrição foi avaliado pela ocorrência simultânea de um ou mais destes atributos.

$\mathbf{X}_{\mathbf{3}}=$ variável diâmetro médio da partícula, ou DMP, expresso em $\mathrm{mm}$; calculado segundo a expressão:

$$
\operatorname{DMP}=\Sigma\left(\mathrm{C}_{\mathbf{i}} \mathbf{P}_{\mathrm{i}}\right)
$$

Sendo:

$\mathrm{C}_{\mathrm{i}}=$ Centro da classe textural $i$, expresso em $\mathrm{mm}$

$\mathrm{P}_{\mathrm{i}}=$ Proporção de ocorrência da classe textural $i$, expressa em \%

$\mathbf{X}_{4}=\operatorname{variável}(M O \% *$ "Nova" Areia $) / 100$

As variáveis $\mathrm{X}_{1}, \mathrm{X}_{3}$ (diâmetro médio das partículas) e $\mathrm{X}_{4}$ foram calculadas com base nos dados analíticos do horizonte superficial ou camada de 0 - 20 $\mathrm{cm}$; a variável $\mathrm{X}_{2}$, permeabilidade do solo, foi calculada tomando por base os dados de todo o perfil, até o topo do horizonte C.

A caracterização da erodibilidade foi efetivada para cada local amostrado, sem que se estabelecesse um vínculo com unidades de mapeamento previamente delineadas na área. A abrangente amostragem dos solos em toda a bacia, foi idealizada para permitir a caracterização da estrutura da variância, pela aplicação de métodos geoestatísticos, e a interpolação dos valores medidos, considerando a variabilidade natural dos solos da área. Essa metodologia, também seguida para a caracterização da variação da profundidade do solo na bacia, foi escolhida por ser totalmente compatível com a estrutura da informação dentro do SIG, que armazena o 
dado em células ou pixels. Assim, a interpolação foi efetuada de forma a obter um valor para cada pixel ou unidade básica de armazenamento da informação na imagem.

\subsubsection{Fator LS ou fator topográfico}

$\mathrm{Na}$ adaptação do modelo original, o fator $\mathrm{L}$, ou fator comprimento da encosta, e o fator $\mathrm{S}$, ou fator grau de declividade, foram combinados em um único fator, referido por fator LS ou topográfico, de acordo com a equação desenvolvida por Bertoni \& Lombardi Neto (1990), a seguir:

$$
L S=0,00984 C^{0,63} D^{1,18}
$$

Onde:

$\mathrm{LS}=$ Fator topográfico (adimensional)

$\mathrm{C}=$ Comprimento da vertente, em $m$

$\mathrm{D}=$ Declividade, em \%

Para o cálculo do fator LS, a área da bacia foi inicialmente subdividida em duas categorias: 1) cana-de-açúcar (uso principal); 2) não cana-de-açúcar (outros usos, englobando as áreas com pastagens, matas, reflorestamento, e a pequena porção com culturas anuais). Para cada categoria, foram gerados os mapas de comprimento da vertente $(\mathrm{em} \mathrm{m}$ ) e de declividades (em \%), para aplicação da equação $9 . \mathrm{O}$ cálculo dos comprimentos das vertentes, dentro do SIG, foi efetuado de acordo com os métodos descritos por Rocha, Lombardi Neto \& Bacellar (1995) e Ranieri (1996), com modificações. O fator topográfico foi desenvolvido no IDRISI, sendo que alguns procedimentos, como a aplicação de funções lógicas, foram efetuados na planilha eletrônica Excel v. 1997, da Microsoft.

No SIG, o processo iniciou com a geração do modelo digital de elevação (MDE), a partir da interpolação da imagem de curvas de nível da bacia. Com a imagem $\mathrm{MDE}$, foram gerados mapas de aspecto (em graus) e de declividade (em graus e em porcentagem).

\subsubsection{1 Áreas de não cana-de-açúcar do Ceveiro}

A) Cálculo do comprimento das vertentes 


\section{A) Cálculo do comprimento das vertentes}

Os mapas de aspecto e de declividade foram recortados por uma máscara, que excluiu as áreas com cana-de-açúcar, mantendo apenas a área com outros usos, ou áreas de não cana-de-açúcar. Os mapas foram reclassificados em oito classes, relacionadas a seguir:

- Classes do mapa de aspecto (em graus): 1) $0^{\circ}-45^{\circ}$; 2) $45^{\circ}-90^{\circ}$; 3) $90^{\circ}$ - 135 ; 4) $135^{\circ}-180^{\circ}$; 5) $180^{\circ}-225^{\circ}$; 6) $225^{\circ}-270^{\circ}$; 7) $270^{\circ}-315^{\circ}$; 8) $315^{\circ}-360^{\circ}$.

- Classes do mapa de declividade (em porcentagem): 1) 0 - $2 \%$; 2) $2 \%$ - $5 \%$; 3) $5 \%$ - $10 \%$; 4) $10 \%$ - $15 \%$; 5) $15 \%$ - $20 \%$; 6) $20 \%$ - $25 \%$; 7) $25 \%$ - $45 \%$; 8)> $45 \%$

Os dois mapas reclassificados foram cruzados no IDRISI, resultando em um mapa de polígonos homogêneos (mesma classe de aspecto e de declividade), que foram então individualizados, compondo 6.215 polígonos, referentes à área de não canade-açúcar na bacia (626,08 ha). De cada polígono foi extraído o valor médio da declividade (em graus), da amplitude da altitude (valor máx. - valor mín.; em metros), e $\mathrm{da}$ área (em $h a$ ), que compuseram três arquivos de valores. No editor de texto do SIG, os arquivos de valores (extensão.$v a l$ ) foram convertidos para o formato texto (extensão .txt), e exportados para a planilha eletrônica. No Excel, os arquivos originais foram reunidos em uma única pasta de trabalho, para o cálculo dos comprimentos das vertentes. Calculados os valores do seno das declividades $(\alpha)$, o valor preliminar dos comprimentos da vertente $(L, m)$ foi obtido pela equação 10 :

$$
L=x \operatorname{sen} \propto^{-1}
$$

Sendo:

$\mathrm{L}$ = comprimento da vertente, em $m$ (o que se quer determinar);

$\mathrm{x}=$ amplitude da altitude, em $m$;

$\operatorname{sen} \propto=$ seno da declividade $(\alpha)$, em graus.

O valor inicial calculado, representativo do comprimento da vertente em cada polígono, foi submetido a funções lógicas para prevenir possíveis distorções relacionadas com: 
1) Comprimento $L$, calculado pela equação 10 , maior do que o comprimento máximo possível, em função do tamanho do polígono. Exemplificando para um polígono de área equivalente a um pixel (ou de $20 \mathrm{~m} \times 20 \mathrm{~m}$ ), o máximo comprimento da vertente possível seria o valor da diagonal, ou de $(20 *$ RAIZ2 $)=28,28427 \mathrm{~m}$, e em apenas duas posições, que correspondem às duas diagonais. A maior probabilidade é de que os comprimentos sejam iguais ou menores do que o valor do lado do píxel (ou de $20 \mathrm{~m}$ ). A equação 10, pode gerar, no entanto, valores maiores. Para prevenir esta distorção, os valores calculados foram confrontados com valores máximos, tentativamente definidos em função da área dos polígonos. Para um polígono constituído por um píxel (área = $0,04 \mathrm{ha}$ ), foi relacionado um valor máximo mais provável de $20 \mathrm{~m}$. Para um polígono constituído por dois píxels (área $=0,08$ ha), o comprimento máximo mais provável foi considerado como sendo igual ao valor da soma dos dois lados $(20 m+20 m=40 m)$; para um polígono de três pixxels (área $=1,2 \mathrm{ha}$ ), um comprimento máximo equivalente a $60 \mathrm{~m}$ (soma de três lados), e assim sucessivamente. A função lógica definiu que:

Se $L_{\text {calculado }} \leq L_{\text {máximo }} \rightarrow L=L_{\text {calculado }}$

Se $L_{\text {calculado }}>L_{\text {máximo }} \rightarrow L=L_{\text {máximo }}$

2) O comprimento calculado pela equação 10 tende a infinito, quando a declividade média no polígono tende a zero (relevo plano), uma vez que o seno de $\alpha$ também tende a zero. Isto não representa a realidade. A função lógica definiu que:

Se $\operatorname{sen} \alpha \cong 0 \rightarrow L=L_{\text {máximo }}$

Se $\operatorname{sen} \alpha>0 \rightarrow L=L_{\text {calculado }}$

$\operatorname{Se} L_{\text {calculado }}>L_{\text {máximo }} \rightarrow L=L_{\text {máximo }}$

C) O comprimento calculado ( $\mathrm{L}_{\text {calculado }}$ ) se anula quando a amplitude da altitude é igual a zero, isto é, a altitude é mesma em todo o polígono $(x=0)$. No entanto, isto não corresponde à realidade. Neste caso, o comprimento do declive também foi considerado como sendo igual ao valor máximo permitido pelo tamanho do polígono, segundo a função lógica:

Se $\mathrm{x}=0 \rightarrow L=L_{\text {maximo }}$ 
Ao final do processo, o arquivo com os valores de $L$ final, definido por polígono da área de não cana-de-açúcar, foi exportado para o SIG, compondo um arquivo de valores que foi rasterizado, originando o mapa de comprimentos das vertentes das áreas de não cana-de-açúcar do Ceveiro. Este mapa foi elevado ao fator 0,63, de acordo com o descrito na equação 9, de Bertoni \& Lombardi Neto (1990).

\section{B) Obtenção do mapa de declividades}

A partir do mapa de original de declividades (não reclassificado), das áreas de não cana-de-açúcar, foram extraídos os valores da declividade média por polígono das áreas de não cana-de-açúcar, compondo um arquivo de valores (extensão .val). $\mathrm{O}$ arquivo de valores, resultante, convertido em arquivo texto, (formato .txt), foi exportado para a planilha eletrônica.. Nos polígonos onde a declividade média apareceu como sendo nula, o zero foi substituído por $0,00992 \%$ (menor valor do conjunto de 6215 polígonos), para diferenciar a área sob análise, do fundo da imagem, que no IDRISI tem valor igual a zero. No editor do SIG, foi reeditado o arquivo de valores corrigido, e gerado um novo mapa de declividades das áreas de não cana-de-açúcar do Ceveiro. Este novo mapa foi elevado ao fator 1,18 , de acordo com o descrito na equação 9, de Bertoni \& Lombardi Neto (1990).

Os mapas de comprimentos da vertente e de declividades, elevados aos respectivos fatores, foram multiplicados entre si, e o produto multiplicado pelo fator 0,00984 (Equação 9), compondo o mapa do fator topográfico (ou do fator LS) para as áreas de não cana-de-açúcar.

\subsubsection{2 Áreas com cana-de-açúcar}

\section{A) Cálculo do comprimento das vertentes}

$\mathrm{Na}$ área de cana-de-açúcar $(1.319,64 \mathrm{ha})$, os procedimentos levaram em conta que o terraceamento é uma prática conservacionista comum no manejo da cultura. Neste caso, pode ser considerado que o comprimento da vertente corresponde à distância entre terraços. Sabendo-se que o critério adotado pelos produtores do Ceveiro para locação dos terraços, é de aproximadamente um terraço a cada $5 \mathrm{~m}$ de desnível do 
terreno (isto é, adotam um $E V$ terraço $=5 \mathrm{~m}$ ), fixou-se o valor de $x$ (desnível ao longo da vertente), na equação 10 , como sendo de $5 \mathrm{~m}$. A equação para cálculo dos comprimentos das vertentes nas áreas de cana-de-açúcar ficou sendo:

$$
L=5 \operatorname{sen} \alpha^{-1}
$$

Sendo:

$\mathrm{L}=$ comprimento da vertente, em $m$ (o que se quer determinar);

sen $\propto=$ seno da declividade $(\alpha)$, em graus.

Em uma vertente com $2 \%$ de declividade (ou declividade de $1^{\circ}$ ), o espaçamento entre terraços, calculado pela Equação 11, é de cerca de $286 \mathrm{~m}$; para uma declividade de $3,5 \%$ (ou de $2^{\circ}$ ), o comprimento calculado é de cerca de $143 \mathrm{~m}$, e assim por diante. Normalmente, não é recomendável que o espaçamento máximo entre terraços ultrapasse em muito a $120 \mathrm{~m}$. De acordo com trabalho de Bertoni \& Lombardi Neto (1990), os espaçamentos máximos recomendados, em relação à declividade, são apresentados na Tabela 3.

Tabela 3-Comprimento máximo da vertente (em metros), em função da declividade, segundo Bertoni \& Lombardi Neto, 1990).

\begin{tabular}{cc}
\hline Declividade (\%) & Comprimento (m) \\
\hline 2 & 120 \\
$4-6$ & 90 \\
8 & 60 \\
10 & 30 \\
12 & 24 \\
$14-24$ & 18 \\
\hline
\end{tabular}

O mapa de declividades (em \%) para as áreas de cana-de-açúcar da bacia, foi reclassificado em cinco classes. Os polígonos resultantes foram individualizados, resultando em 3446 polígonos. A Tabela 4 relaciona as cinco classes de declividade; o comprimento $L$ ( $\mathrm{em} m$ ) calculado pela equação 11 , para o valor central aproximado de cada classe de declividade, convertido em graus; e o comprimento $L$ adotado (em $m$ ), tomando por base os valores calculados, em comparação com aqueles recomendados, conforme a Tabela 3. 
Tabela 4-Comprimento da vertente (em metros), por classe de declividade, para a área de cana-de-açúcar na bacia hidrográfica do Ceveiro.

\begin{tabular}{ccc}
\hline $\begin{array}{c}\text { Classe de Declividade } \\
(\%)\end{array}$ & \multicolumn{2}{c}{ Comprimento (m) } \\
Calculado & Adotado \\
\hline $0-5$ & 143 & 140 \\
$5-10$ & 72 & 70 \\
$10-15$ & 41 & 40 \\
$15-20$ & 29 & 30 \\
$>20$ & 22 & 25 \\
\hline
\end{tabular}

Com os comprimentos adotados (conforme a Tabela 4), foi editado um arquivo de valores, e gerado o mapa preliminar dos comprimentos das vertentes das áreas com cana-de-açúcar do Ceveiro. $\mathrm{Na}$ planilha eletrônica, os valores atribuídos a cada polígono foram confrontados com funções lógicas, para que não excedessem aos valores máximos mais prováveis, definidos em função da área do polígono, à semelhança do que foi relatado para as áreas de não cana-de-açúcar da bacia. No IDRISI, o arquivo de valores com os comprimentos finais ( $L_{\text {final }}$ ) foi reeditado e gerado o mapa do comprimento das vertentes das áreas de cana-de-açúcar. Esse mapa foi elevado ao fator 0,63, para ser utilizado no cálculo do fator LS (conforme Equação 9).

\section{B) Obtenção do mapa de declividade}

A partir do mapa de cinco classes de declividade das áreas de cana-deaçúcar (conforme Tabela 4), individualizado em 3.446 polígonos, foram extraídos os valores médios da declividade (em \%) por polígono. $\mathrm{O}$ arquivo de valores resultante (extensão .val) foi convertido em um arquivo tipo texto (formato .txt), e importado na planilha eletrônica. No Excel, nos polígonos em que a declividade média era igual a zero, esse valor foi substituído por $0,268457 \%$ (menor valor maior do que zero), registrado dentre os 3.446 polígonos). Este procedimento foi novamente adotado, para evitar valor zero dentro da área com cana-de-açúcar, diferenciando-a do fundo da imagem. $\mathrm{O}$ arquivo de valores assim corrigido, foi reeditado no SIG, e utilizado para gerar a imagem com as declividades médias (em \%), por polígono de cana, compondo o mapa de declividades das áreas de cana-de-açúcar do Ceveiro. Esse mapa foi elevado ao fator 1,18 , conforme equação 9 . 
De modo semelhante ao que foi feito para as áreas de não cana-deaçúcar da bacia, o mapa do fator topográfico (ou fator LS) das áreas de cana-deaçúcar foi obtido multiplicando, entre si, os mapas de comprimento das vertentes e das declividades médias (elevados aos seus respectivos fatores), multiplicando o produto resultante pelo fator 0,00984 (conforme equação 9).

\subsubsection{Fator $\mathrm{C}$ ou fator de cobertura e manejo da cultura}

O Fator C para a cana-de-açúcar foi estimado por De Maria ${ }^{2}$, tendo por base a razão entre a cobertura e a perda de solo, nos diferentes estágios de desenvolvimento da cultura, considerando um ciclo de 18 meses (cana de ano e meio) e o sistema de manejo médio aplicado à cultura na bacia do Ceveiro (sem adubação verde ou cobertura do solo no verão). Para os demais tipos de uso, os valores do Fator C foram extraídos do trabalho de Ranieri (1996), com modificações. A tabela 5 relaciona os tipos de uso e os respectivos valores do Fator $\mathrm{C}$.

Tabela 5- Fator $C$ por categoria de uso da terra na bacia hidrográfica do Ceveiro.

\begin{tabular}{lc}
\hline \multicolumn{1}{c}{ Uso da Terra } & Fator C \\
\hline Cana-de-aćúcar & 0,3066 \\
Pastagens $^{2}$ & 0,0080 \\
Cultura Anual $^{2}$ & 0,5500 \\
Reflorestamento $^{2}$ & 0,0010 \\
Matas $^{2}$ & 0,0001 \\
Vegetação ciliar $^{2}$ & 0,0001 \\
\hline
\end{tabular}

1 De Maria, comunicação pessoal; trabalho em fase de redação.

2 Extraído de Ranieri (1996), com modificações.

\subsubsection{Fator $P$ ou fator prática de controle da erosão}

Nas áreas de cana-de-açúcar e de cultura anual, o plantio em contorno confere fator $\mathrm{P}$ igual a 0,5 . Para os demais usos, o fator P é igual a 1,0 (Bertoni \& Lombardi Neto, 1990).

Após o ajuste dos fatores R, K, LS, C e P às condições locais da bacia do Ceveiro, a USLE (Wischmeier \& Smith, 1978) foi aplicada dentro do SIG, e as taxas atuais de perda de solo (A, em $M g h a^{-1} a n o^{-1}$ ) foram estimadas para as áreas de

\footnotetext{
${ }^{2}$ Comunicação Pessoal da Dra. Isabella Clerici De Maria, pesquisadora do Centro de Solos e Recursos Ambientais do IAC.
} 
cana-de-açúcar (uso principal) e de não cana-de-açúcar (outros usos); os resultados foram então combinados para representar a perda de solo em toda a área da bacia do Ceveiro.

\subsection{Métodos Estatísticos}

\subsubsection{Caracterização dos Solos}

Os resultados analíticos das amostras de solos foram tratados pelos métodos da estatística clássica para obtenção dos valores da média aritmética, desvio padrão, coeficiente de variação, mediana e valores mínimo e máximo, dos atributos físicos e químicos, com vistas à caracterização dos solos da bacia.

\subsubsection{Obtenção de parâmetros por interpolação}

Como comentado anteriormente, seção 3.6.2 foram interpolados os valores da erodibilidade e da espessura dos horizontes (A+B). A interpolação foi efetuada pelo método da krigeagem (kriging), considerando a variabilidade espacial dos solos da bacia, de acordo com os métodos geoestatísticos de análise, anteriormente descritos na revisão de literatura (Seção 2.5.2).

Para a erodibilidade, foi ajustado um semivariograma do tipo exponencial (Parâmetros: $\mathrm{C}_{0}=0,5 ; \mathrm{C}_{1}=0,65 ; \mathrm{a}=700 \mathrm{~m}$ ) e para a profundidade do solo, foi ajustado um semivariograma do tipo esférico (Parâmetros: $\mathrm{C}_{\mathrm{o}}=0,3 ; \mathrm{C}_{1}=0,8 ; \mathrm{a}=$ $1400 \mathrm{~m}$ ). O cálculo das semivariâncias e a interpolação pelo método da krigeagem foram efetuados utilizando o programa computacional desenvolvido por Vieira ${ }^{3}$. O ajuste dos semivariogramas foi efetuado em planilha eletrônica (Excel v. 97, da Microsoft). Com os parâmetros dos semivariogramas, a interpolação foi executada para a área da bacia, considerando uma malha de $20 \mathrm{~m} \mathrm{x} 20 \mathrm{~m}$, igual ao tamanho do píxel (célula básica de armazenamento de dados no SIG). Os dados interpolados foram exportados para o programa Surfer (Surfer Mapping System win 32, 1993-95; Golden Software Inc.), no qual foram gerados dois arquivos em formato .grd (do tipo ASCII), que foram então importados para o IDRISI, e recortados no tamanho da bacia,

\footnotetext{
${ }^{3}$ Dr. Sidney Rosa Vieira, pesquisador do Centro de Solos e Recursos Ambientais do IAC.
} 
compondo os mapas interpolados da erodibilidade e da profundidade dos solos do Ceveiro.

\subsubsection{Estudo de sensibilidade dos fatores do modelo USLE}

Foram efetuados testes de médias das taxas de perda de solo estimadas pela USLE (A, em $\mathrm{Mg} \mathrm{ha}{ }^{-1}$ ano $^{-1}$ ), por categoria de uso da terra da bacia, para caracterização de diferenças significativas da perda média por tipo de uso. Foi utilizado o programa estatístico SAS, v. 5 (SAS Institute, 1991). Também foi analisada, através de gráficos de dispersão e por simulação de cenários, a influência do fator K (ou fator erodibilidade do solo) e do fator LS (ou fator topográfico), na variação das taxas de perda de solo estimadas, por categoria de uso e para a bacia como um todo. $O$ fator $R$ (ou fator erosividade da precipitação e da enxurrada), constante para toda a bacia, não participou da análise.

\subsection{Metodologia do Índice de Tempo de Vida}

Foi definido um índice de sustentabilidade, baseado nas taxas atuais de perda de solo (A, em $\mathrm{Mg} \mathrm{ha}^{-1}$ ano $^{-1}$ ), estimadas pela USLE, em uma taxa presumida de renovação do solo de $0,2 \mathrm{~mm}$ ano $^{-1}$ (extraída do trabalho de Skidmore, 1982), e na espessura do solo "disponível" para perda (conforme o conceito funcional de tolerância, como caracterizado nos trabalhos de Stamey \& Smith, 1964; Skidmore, 1982; e, Sparovek \& van Lier, 1997). O índice de sustentabilidade desenvolvido, remete ao tempo remanescente para atingir uma condição de degradação irreversível, tendo sido denominado índice de tempo de vida. A condição de impacto irreversível foi definida pela ocorrência de uma profundidade mínima de solo, abaixo da qual sua qualidade é severamente degradada, em prejuízo do desempenho de suas múltiplas funções como recurso natural e como componente do ambiente.

Foram consideradas duas profundidades para análise, correspondentes a $50 \mathrm{~cm}$ e $100 \mathrm{~cm}$. Estes valores foram escolhidos tendo em vista a profundidade média dos solos da bacia. Nas áreas da bacia, em que os solos já estão mais rasos do que $50 \mathrm{~cm}$ ou $100 \mathrm{~cm}$, foi caracterizada a situação de impacto irreversivel instalado no tempo atual, isto é, qualquer perda adicional da espessura do solo por erosão, é 
insustentável no tempo zero.

Nos locais da bacia, de solos mais profundos do que as profundidades críticas de $50 \mathrm{~cm}$ e de $100 \mathrm{~cm}$, continuaram os procedimentos para o cálculo do índice de sustentabilidade proposto. A partir do mapa de profundidade do solo, com os valores interpolados da espessura dos horizontes $(A+B)$, foram realizadas operações no SIG, para cálculo das espessuras "disponíveis" para perda. O mapa original da profundidade interpolada, foi subtraído dos valores de $50 \mathrm{~cm}$ e de $100 \mathrm{~cm}$, obtendo-se dois outros mapas com as espessuras "líquidas" de solo, ou espessuras "disponíveis", para os cálculos do índice de sustentabilidade. Para os cálculos, as taxas de perda de solo estimadas (A, em $M g h a^{-I} a n o^{-1}$ ) foram convertidas em alturas de solo perdidas por erosão (h, em $m m^{a n o^{-1}}$ ), utilizando um valor médio de densidade do solo, de $1,602 \mathrm{~g} \mathrm{~cm}^{-3}$, determinado experimentalmente para os solos da bacia, conforme descrito na seção 3.5. A equação 12, ilustra a conversão da taxa de perda de solo (A, em $M g h a^{-1} a n o^{-1}$ ), em altura de solo (h, em $m m a n o^{-1}$ ):

$$
h=10 \mathrm{~A} / \mathrm{d}
$$

Onde:

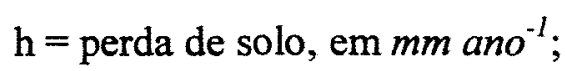

$\mathrm{A}=$ taxa de perda de solo, em $M g h a^{-1} a n o^{-1}$ (estimada pela USLE);

$\mathrm{d}=$ densidade do solo, em $\mathrm{g} \mathrm{cm}^{-3}$.

Descontando-se a taxa presumida de renovação do solo ( $\mathrm{f}=0,2 \mathrm{~mm}$ $\left.a_{n o}^{-1}\right)$, da altura estimada de perda de solo por erosão (h, em mm ano ${ }^{-1}$ ), obteve-se um mapa com a perda "líquida" de solo $\left(\mathrm{h}_{1}\right)$. Neste mapa, valores negativos indicaram a ocorrência de perda de solo inferior à taxa de renovação $(p<f)$, condição particular na qual o solo está se espessando (conservação do solo e da água na condição atual). Preliminarmente, foram separadas as áreas onde a formação supera a perda ( $\mathrm{f}>\mathrm{p} \rightarrow$ conservação) e onde a perda supera a formação ( $\mathrm{p}>\mathrm{f} \rightarrow$ degradação). Nas áreas onde a perda supera a formação (área se degradando) e não está caracterizada uma condição de impacto irreversível no momento atual (os solos são mais profundos do que a profundidade crítica considerada), é que foram calculados os índices de tempo de vida 
(em anos).

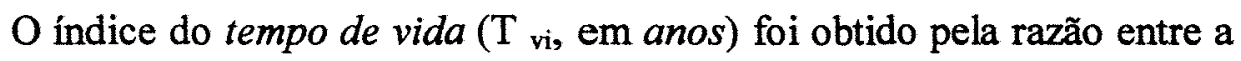
altura de solo "disponível" para perda ( $\mathrm{a}, \mathrm{em} \mathrm{mm})$, e a perda "líquida" de solo $\left(\mathrm{h}_{\mathrm{l}}\right.$, em $\left.m m a n o^{-1}\right)$, como ilustrado na expressão a seguir:

$$
\mathbf{T} \mathbf{V}_{\mathbf{i}}=\mathbf{a} \mathbf{h}_{\mathbf{l}}^{-1}
$$

Sendo:

$\mathrm{T} \mathrm{V}_{\mathrm{i}}=$ índice de tempo de vida, em anos;

$\mathrm{a}=$ altura de solo "disponível" para perda, em $\mathbf{m m}$;

$\mathrm{h}_{\mathrm{l}}=$ perda "líquida" de solo, em $m \mathrm{mano}^{-1}$.

Dos mapas de tempo de vida (informação espacializada), foram extraídos no IDRISI, histogramas de freqüência, relativos às classes de tempo e área acumulada. $O$ conjunto de informações foi exportado para a planilha eletrônica, sendo obtidos gráficos de dispersão, relativos ao tempo de vida e a área acumulada, integrando toda a informação gerada, para avaliação do impacto da erosão acelerada na bacia.

As áreas de cana-de-açúcar (uso principal) e de não cana-de-açúcar (outros usos), foram analisadas separadamente. Foram gerados mapas e gráficos de tempo de vida para cada categoria. Foi adotado este critério, pelo interesse em estudar isoladamente o impacto da cultura da cana-de-açúcar na bacia. Ao final do processo, os resultados obtidos separadamente para as duas grandes categorias de uso, foram reunidos e consolidados para caracterização da bacia como um todo.

Preliminarmente, foi realizado um teste metodológico, utilizando dados disponíveis acerca dos solos da bacia, que foi publicado em Sparovek et al. (1997). No presente trabalho, no entanto, é que se apresenta o detalhamento do método para cálculo do índice de sustentabilidade proposto, já com modificações introduzidas, decorrentes do teste preliminar, e utilizando o banco de dados especialmente coletados para a pesquisa. 


\section{RESULTADOS E DISCUSSÃO}

\subsection{A bacia hidrográfica do Ribeirão do Ceveiro (BHC)}

A BHC está inserida em uma das regiões mais urbanizadas, industrializadas e agricultadas do Estado de São Paulo. O desmatamento na região de Piracicaba, deu-se para implantação da agricultura, sendo que o início da exploração agrícola, provavelmente ocorreu com a cafeicultura. Com o declínio da cultura, que se seguiu à geada de 1918 e à grande incidência da broca, houve a substituição do café por culturas anuais e semi-perenes, principalmente arroz, feijão, milho, algodão e cana-deaçúcar (Barthelmess, 1958). Desde então, a região de Piracicaba, tornou-se tradicional produtora de cana-de-açúcar no Estado de São Paulo, protagonizando uma grande expansão da cultura a partir de 1973, com a implantação do Programa Nacional do Álcool (Proálcool), que incentivou a substituição da gasolina pelo etanol. Em menos de trinta anos, a área cultivada com cana-de-açúcar passou de cerca de 62.000 ha, em 1962, para mais de 86.000 ha, em 1991, representando um salto de $35 \%$ para $49 \%$ da área cultivada (Sparovek \& Lepsch, 1995).

A bacia do Ceveiro ilustra esta situação, encontrando-se ainda predominantemente ocupada com a cultura da cana-de-açúcar. São cerca de 1.319 ha sendo ocupados com a cultura, correspondentes a $67,8 \%$ da área total avaliada. A menos de $15 \mathrm{~km}$ de uma grande usina de açúcar e álcool, essa grande proximidade deve explicar a utilização predominante das terras com a cultura, apesar da condição marginal dos solos ao uso intensivo. A sobreutilização das terras é sugerida pelo estado adiantado de degradação do meio físico, que se materializou na sedimentação acentuada do açude a jusante da bacia. Construído com a finalidade de abastecer com água potável a população de cerca de 2.000 habitantes do Distrito de Ártemis, o açude foi projetado 
para uma vida útil de 25 anos, mas acabou desativado passados apenas 12 anos da implantação, em função do assoreamento.

O mapa do uso das terras do Ceveiro (Figura 4), mostra a distribuição da cultura da cana-de-açúcar e das demais categorias de uso. A maior ocupação, após a cultura da cana, dá-se com pastagens (277,66 ha ou $14,3 \%$ da área avaliada), seguida por mata $(225,36$ ha ou $11,6 \%)$ e por reflorestamento (120,12 ha ou $6,2 \%)$. A área ocupada com cultura anual é de apenas 2,96 ha, ou de menos de $0,2 \%$ da área total avaliada de 1945,72 ha. A vegetação original, do tipo mesófila semidecídua, restringe-se a alguns trechos próximos à rede de drenagem e às porções mais movimentadas do relevo.

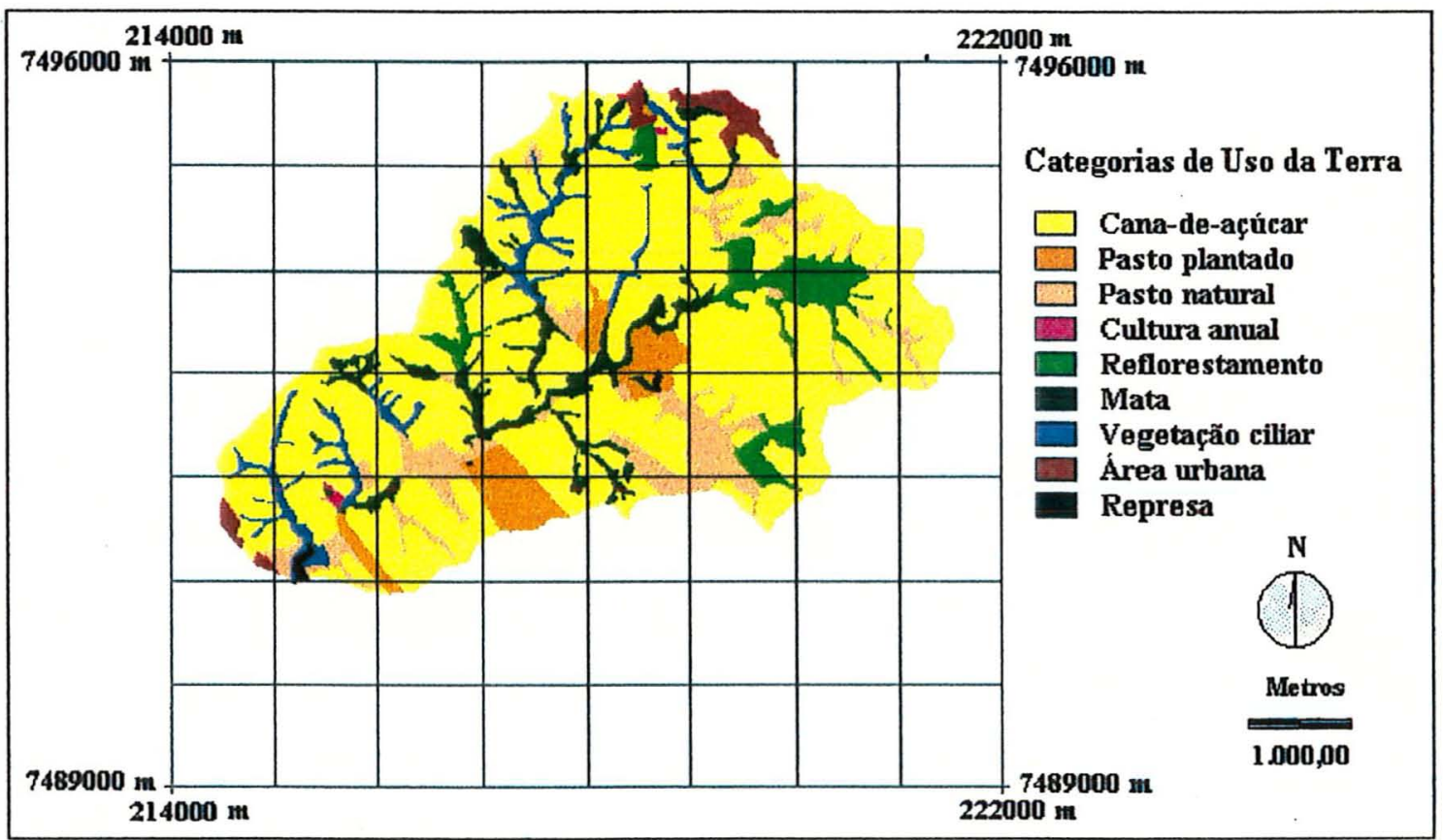

Figura 4- Mapa do uso das terras da bacia do Ribeirão do Ceveiro. Ano base: 1995.

O relevo da bacia se caracteriza por uma topografia de morros, suave ondulado, com cotas variando entre 460 a 580 metros. A declividade predominante nas encostas, situa-se na faixa entre $5 \%$ e $15 \%$. Nos topos, a declividade é inferior a $5 \%$. À margem esquerda do Ribeirão Ceveiro, a litologia se compõe de rochas de granulação fina a média, representadas por siltitos, argilitos e folhelhos, relacionados com a 
Formação Corumbataí, do Grupo Passa Dois. À margem direita, concentram-se arenitos da Formação Pirambóia, do Grupo São Bento. Nas cabeceiras, em pequena proporção, ocorrem rochas intrusivas básicas da Formação Serra Geral, também pertencente ao Grupo São Bento, recobrindo os arenitos da Formação Pirambóia (IPT, 1981).

O clima, pela classificação de Köppen, corresponde ao Cwa, que designa clima mesófilo úmido sub-tropical com inverno seco e temperatura do mês mais quente superior a $22^{\circ} \mathrm{C}$. O balanço hídrico ${ }^{\prime}$ calculado para Piracicaba, segundo metodologia de Thornthwaite \& Matter (1955), para o ano normal representado na Tabela 2 (Seção 3. 6. 1), considerando uma capacidade de armazenamento de água no solo de $100 \mathrm{~mm}$, indicou a ocorrência de pequeno déficit hídrico nos meses de julho a setembro, com valor médio de $8,6 \mathrm{~mm}$, situado entre o mínimo de $4,8 \mathrm{~mm}$ e o máximo de $13,2 \mathrm{~mm}$. Os excedentes hídricos ocorrem durante o verão, nos meses de dezembro a março. $O$ valor médio para a série de 80 anos de registros foi de $70,7 \mathrm{~mm}$, situado entre o valor mínimo de $24,4 \mathrm{~mm}$ e o máximo de $95,4 \mathrm{~mm}$.

\subsection{Os solos da BHC}

O levantamento pedológico semi-detalhado (escala 1:100.000) executado para a quadrícula de Piracicaba (INSTITUTO AGRONÔMICO, 1989), indica a predominância na bacia de Solos Podzólicos Vermelho-Amarelos, de textura arenosa sobre média ou média sobre argilosa, fases profunda e pouco profunda, relacionados às unidades de mapeamento Serrinha, Santa Cruz e Baguari. Também há ocorrência significativa de Solos Litólicos e Cambissolos. Em pequena proporção ocorrem Podzólico Vermelho-Escuro, Terra Roxa Estruturada (Unidade Estruturada), Terra Roxa Estruturada Podzólica (Unidade Santana), Solo Podzolizados com cascalhos e cascalhentos, e Solos Hidromórficos.

A variação da profundidade do solum na bacia do Ceveiro, foi estimada a partir da interpolação de valores medidos, pelo método da krigeagem (kriging). Foi ajustado aos dados originais, um semivariograma do tipo esférico, cujos parâmetros foram: efeito pepita $\left(\mathrm{C}_{0}\right)$ igual a 0,3 ; patamar $\left(\mathrm{C}_{0}+\mathrm{C}_{1}\right)$ igual a 1,1 ; e alcance (a), igual a

\footnotetext{
${ }^{1}$ Dados cedidos pelo Departamento de Ciências Exatas da ESALQ.
} 
$1.400 \mathrm{~m}$ (Figura 5). O mapa interpolado que ilustra a variação da espessura dos solos na bacia do Ceveiro é apresentado na Figura 6. Considerando que solo profundo é aquele com mais de $200 \mathrm{~cm}$ de espessura do solum (EMBRAPA, 1988), a observação da Figura 6 revela que predominam na bacia, solos rasos ou pouco profundos. $\mathrm{Na}$ bacia, os solos mais espessos (profundidade superior a $80 \mathrm{~cm}$ ), são de textura média arenosa, mais permeáveis, e ocorrem predominantemente em sua porção oriental (cores verde e azul), associados aos arenitos da Formação Pirambóia. Em oposição, os solos da porção ocidental, (cores vermelha e amarela) são rasos em sua maioria (profundidade até 50 $\mathrm{cm}$ ). Apresentando-se com textura média argilosa e argilosa, estes solos estão associados ao embasamento pouco permeável, constituído por siltitos, argilitos e folhelhos da Formação Corumbataí.

A profundidade média dos solos, ponderada em relação à área de ocorrência, é de $76 \mathrm{~cm}$, variando entre os valores mínimo de $23 \mathrm{~cm}$ e máximo de 184 $\mathrm{cm}$; o coeficiente de variação (CV \%) é de 37,5\%. A Tabela 6 mostra a distribuição da profundidade do solo, em relação à proporção da área acumulada na bacia. Os dados revelam que os solos rasos, ou com até $50 \mathrm{~cm}$ de profundidade, ocorrem em $21,3 \%$ da área $(414,44 \mathrm{ha})$; em $77,3 \%$ da área $(1.503,85 \mathrm{ha})$, a profundidade é igual ou inferior a 100 cm; e em 99,99 \% da área $(1.945,52$ ha), a profundidade não ultrapassa a $180 \mathrm{~cm}$.

Tabela 6- Distribuição da profundidade dos solos na bacia hidrográfica do Ribeirão do Ceveiro, em relação à área acumulada.

\begin{tabular}{cc}
\hline Profundidade do solo até & Área acumulada \\
\hline $\mathbf{c m}$ & $\%$ \\
40 & 10,40 \\
50 & 21,43 \\
70 & 46,98 \\
80 & 58,79 \\
100 & 77,29 \\
120 & 93,23 \\
180 & 99,99 \\
\hline
\end{tabular}

A Tabela 7 mostra os valores da média aritmética, desvio padrão, coeficiente de variação, mediana e valores mínimo e máximo para nove atributos físicos e químicos dos solos da bacia do Ceveiro. Os 


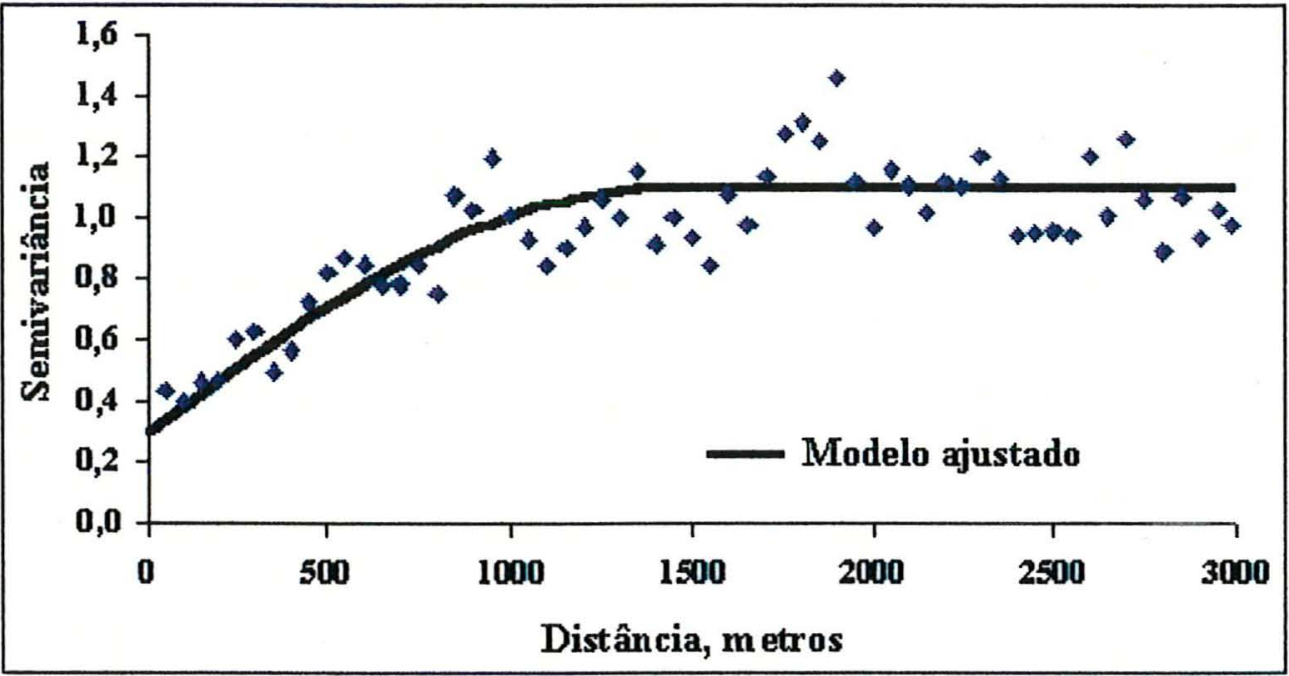

Figura 5-Semivariograma para a profundidade do solo na bacia hidrográfica do Ribeirão do Ceveiro. Modelo esférico: parâmetros $(\mathrm{Co}=0,3 ; \mathrm{C} 1=0,8 ; \mathrm{a}=1.400)$.

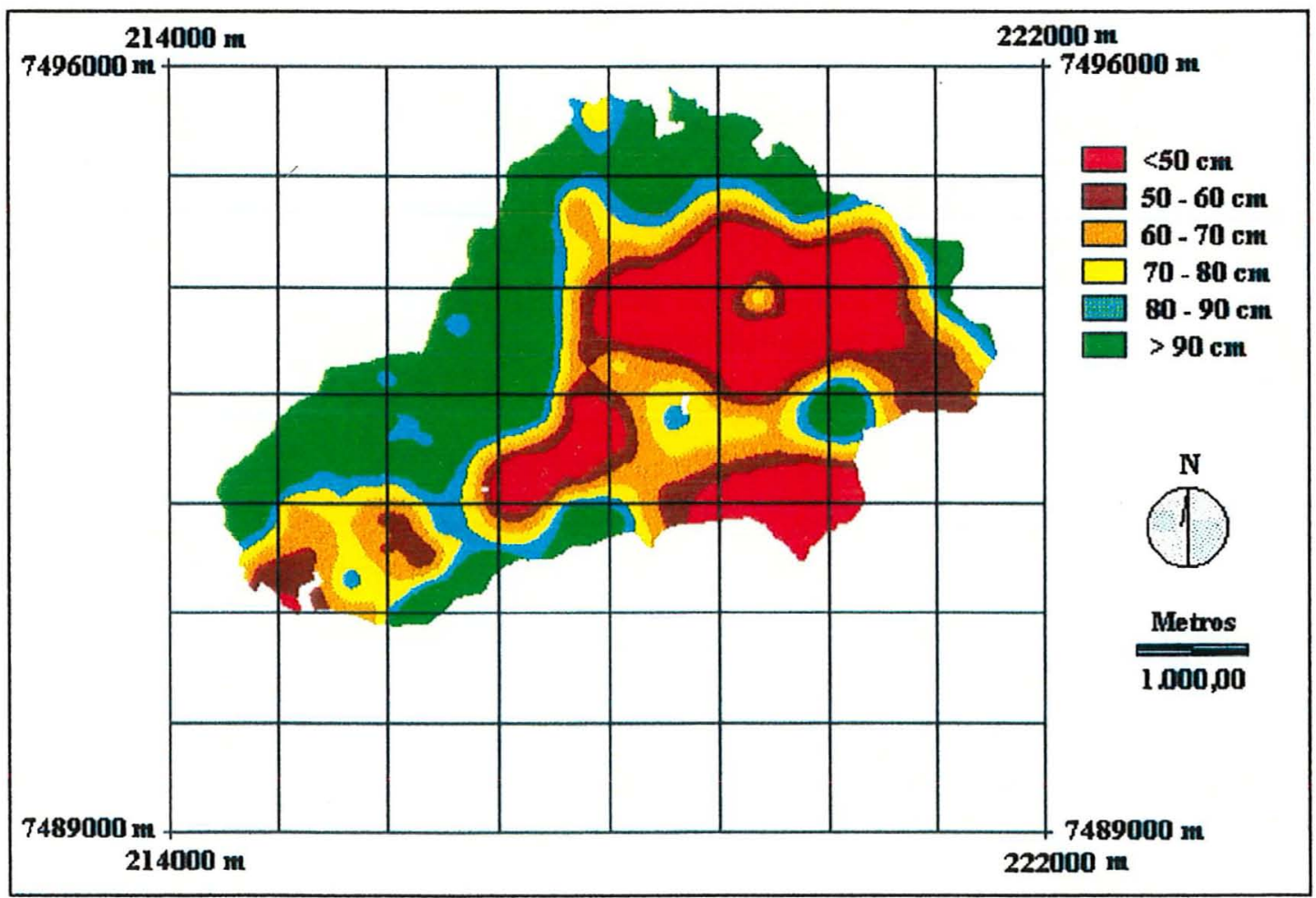

Figura 6- Profundidade do solo na bacia hidrográfica do Ribeirão do Ceveiro. 
Tabela 7- Parâmetros estatísticos de nove atributos físicos e químicos dos solos da bacia hidrográfica do Ribeirão do Ceveiro.

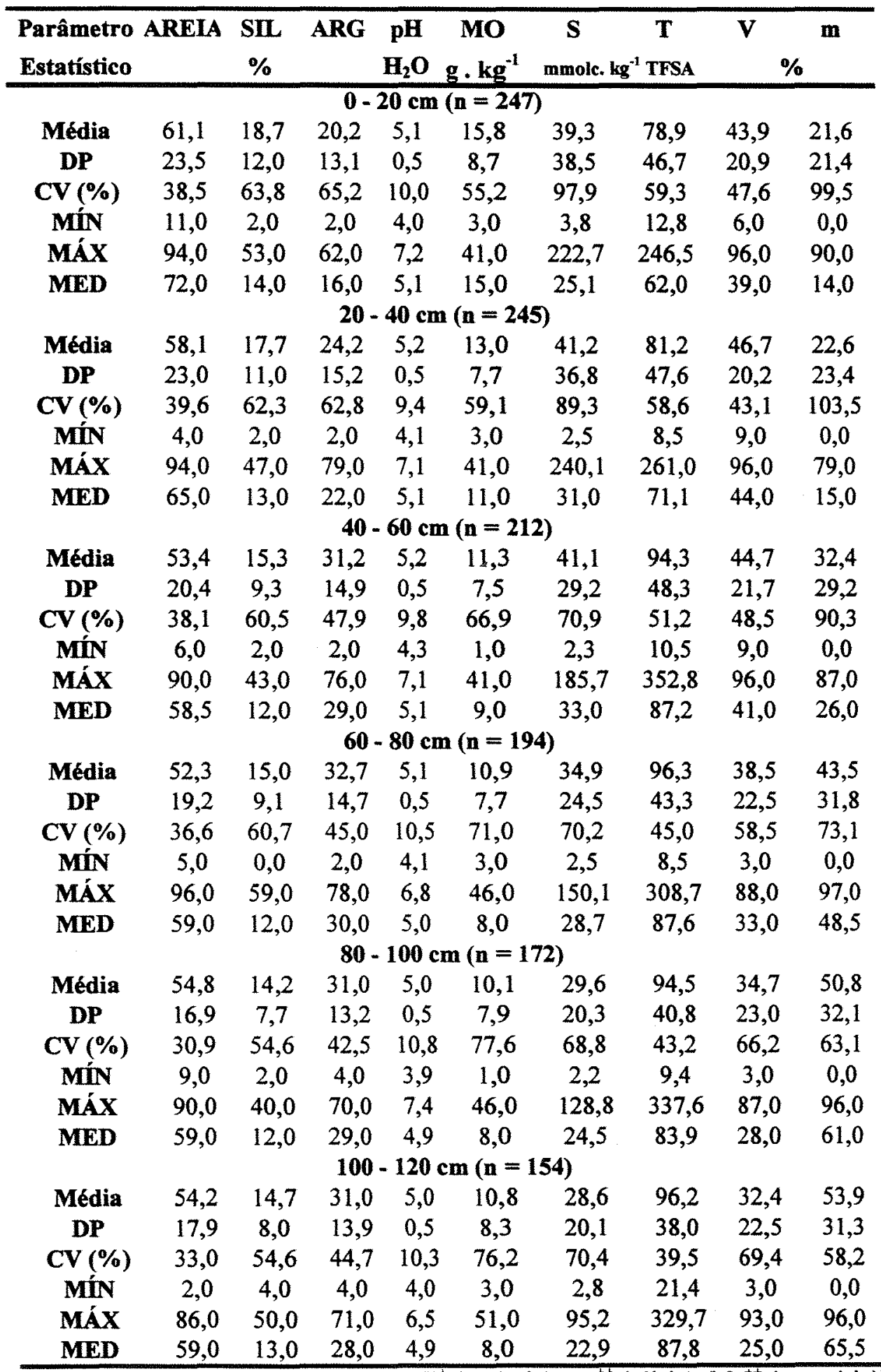

Simbolos: $\mathrm{S}$, soma de bases trocáveis $\left(\mathrm{K}^{+}\right.$(potássio), $\mathrm{Ca}^{++}$(cálcio), $\mathrm{Mg}^{++}$(magnésio)); $\mathrm{T}$, capacidade de troca de cátions $\left(\mathrm{S}+\left(\mathrm{Al}^{\mathrm{l+H}}+\mathrm{H}^{\mathrm{t}}\right)\right)$; $\mathrm{V}$, saturação por bases $(100 *(\mathrm{~S}$ ( T)); m, saturação por alumínio $\left(100 *\left(\mathrm{Al}^{+++} / \mathrm{Al}^{+++}+\mathrm{S}\right)\right) ; \mathrm{n}$, número de amostras consideradas na análise; DP (desvio padrão); $\mathrm{CV}$ (coeficiente de variação); MíN. (valor mínimo); MÁX. (valor máximo); MED. (mediana). 
valores são apresentados por camada, considerando o conjunto de amostras analisadas em cada camada. Os nove atributos selecionados foram: areia total, silte, argila, $\mathrm{pH}$ em água, matéria orgânica, soma de bases trocáveis, capacidade de troca de cátions, saturação por bases, e saturação por alumínio trocável. Os resultados das análises físicas e químicas para 21 atributos (dados completos), parte integrante do banco de dados organizado para a bacia do Ceveiro, não são apresentados, estando disponíveis para consulta no Departamento de Solos e Nutrição de Plantas da ESALQ/ USP.

Os resultados da análise granulométrica indicam que, em termos médios, predominam na bacia, solos de textura média argilosa, ou com teor de argila variando entre $25 \%$ e $34 \%$, a partir de $40 \mathrm{~cm}$ de profundidade (conforme Tabela 7 ). A variação do teor de argila, no entanto, é ampla, entre $2 \%$ e $78 \%$, indicativa da ocorrência desde solos de textura arenosa até os de textura muito argilosa. Nos horizontes superficiais, até $40 \mathrm{~cm}$ de profundidade, a textura é média arenosa, o teor de argila varia entre $15 \%$ e $24 \%$, e a amplitude de variação é a mesma dos horizontes subsuperficiais, entre $2 \%$ e $79 \%$ de argila (conforme Tabela 7). A fração areia, é dominada pelas frações areia fina (cerca de $60 \%$ do total) e areia muito fina (cerca de $19 \%$ do total), para todas as camadas analisadas (dados não apresentados), com influência na susceptibilidade destes solos à erosão, que é alta. É comum a ocorrência de gradiente textural entre horizontes superficiais e subsuperficiais. De acordo com os critérios da EMBRAPA (1988), para solos de textura arenosa ou média arenosa no horizonte superficial, o gradiente textural é definido por um incremento de argila do A para o $\mathrm{B}$, superior a 1,8. Localmente, também foram caracterizados solos com mudança textural abrúpta. Ainda segundo critérios da EMBRAPA (op. cit.), para solos com menos de $20 \%$ de argila no horizonte $\mathrm{A}$ ou E, caracteriza-se mudança textural abrúpta quando o conteúdo de argila no horizonte $\mathrm{B}$ subjacente, aumenta em pelo menos $20 \%$ em teor absoluto, numa distância igual ou inferior a $8 \mathrm{~cm}$, e dobra em alguma parte desse mesmo horizonte. Nos estudos de erosão, o gradiente textural é um importante atributo do solo a ser avaliado, pois sua ocorrência no perfil diminui a permeabilidade do solo e sua capacidade de infiltração de água, aumentando a susceptibilidade à degradação pelo processo erosivo. 
Nos solos da bacia, o $\mathrm{pH}$ em água ( $\mathrm{pH}$ água $)$ varia em torno de 5,0 , em toda a profundidade analisada (conforme Tabela 7), caracterizando reação fortemente ácida pelo critério da EMBRAPA (1988). A amplitude de variação do $\mathrm{pH}$ água, entre 4 e 7, é ampla, mas o coeficiente de variação inferior a $10 \%$, dá consistência ao valor médio de 5,0. $\mathrm{O} \Delta p H\left(\mathrm{pH} \mathrm{CaCl2}_{2}-\mathrm{pH}_{\text {água }}\right.$; dados não apresentados) é sempre negativo, indicando a predominância de cargas negativas no complexo sortivo. Os teores de matéria orgânica até $40 \mathrm{~cm}$, situam-se ao redor de $14,0 \mathrm{~g} \mathrm{~kg}^{-1}$ de TFSA (equivalente a $0,81 \%$ de carbono orgânico); a partir de $40 \mathrm{~cm}$ e até $120 \mathrm{~cm}$, as médias são inferiores, ao redor de $10 \mathrm{~g} \mathrm{~kg}^{-1}$ de TFSA (cerca de $0,6 \%$ de carbono orgânico). Tomando por base o teor mínimo requerido para definição do horizonte $A$ chernozêmico, horizonte mineral de alta fertilidade, de $43 \mathrm{~g} \mathrm{~kg}^{-1}$ de matéria orgânica (equivalente a $2,5 \%$ de carbono orgânico), nos primeiros $18 \mathrm{~cm}$ (pelo critério da EMBRAPA, 1988), pode-se considerar que o teor médio de $14,0 \mathrm{~g} \mathrm{~kg}^{-1}$, representativo dos horizontes superficiais dos solos da bacia do Ceveiro, é baixo, caracterizando horizonte $A$ moderado tendendo para A fraco. A soma de bases trocáveis (S) varia ao redor de $36 \mathrm{mmolc} \mathrm{kg}^{-1} \mathrm{TFSA}_{\text {, }}$ decrescendo em profundidade no solo (conforme Tabela 7), sendo que o cálcio é o cátion predominante (dados não apresentados). Os resultados mostram que até $80 \mathrm{~cm}$, os solos são distróficos, com saturação por bases (V) ao redor de $43 \%$, inferior portanto a $50 \%$; valores superiores a $50 \%$ caracterizariam caráter eutrófico (EMBRAPA, 1988). A partir de $80 \mathrm{~cm}$, os solos passam a ser álicos, isto é a saturação por alumínio trocável $(\mathrm{m})$, é superior a $50 \%$, variando ao redor de $52 \%$. A presença de caráter álico caracteriza impedimento químico ao pleno estabelecimento de raízes, a partir de $80 \mathrm{~cm}$ de profundidade. A toxidez por alumínio restringe a potencialidade do solo ao uso agrícola, pela redução do volume utilizável pela planta, com reflexos sobre a disponibilidade de água e nutrientes. A capacidade de troca de cátions (T) cresce em profundidade no solo, denotando solos jovens, ainda sob influência do material de origem. Até $40 \mathrm{~cm}$, o valor T varia ao redor de 80 mmolc $\mathrm{kg}^{-1}$ de TFSA; a partir de 40 $\mathrm{cm}$, coincidente com o topo do horizonte $\mathrm{B}$, mais rico em argila, o valor $\mathrm{T}$ aumenta para cerca de 95 mmolc $\mathrm{kg}^{-1}$ de TFSA, mantendo esse valor até $120 \mathrm{~cm}$ de profundidade. Como a saturação por bases (V) tende a diminuir em profundidade, conclui-se que o complexo sortivo está saturado por íons ácidos, principalmente o alumínio, como discutido anteriormente. 
Os resultados das análises granulométrica e química dos solos da bacia do Ceveiro, indicam a ocorrência na área, de solos de elevada erodibilidade e potencial de degradação. A granulometria grosseira, rica em areias finas e muito finas, aliada a baixos teores de matéria orgânica condicionam, em conjunto, agregação deficiente. Por outro lado, a presença comum de gradiente textural e de mudança textural abrúpta, entre horizontes superficiais e os de subsuperficie, diminui a permeabilidade do perfil, e sua capacidade de infiltração de água, o que também favorece o processo erosivo. Onde a textura do solo é mais argilosa, associada ao embasamento pouco permeável, os solos são rasos, com contato paralítico, ou são pouco profundos, com horizonte B argiloso, o que também condiciona baixa permeabilidade à água, sugerida pela presença freqüente de mosqueados e cores de redução no topo do horizonte B. Quanto à fertilidade química, presença de alumínio em nível tóxico no subsolo, restringe o estabelecimento de raízes e o desenvolvimento de plantas, por restrições do volume aproveitável do solo e da disponibilidade de água, diminuindo o potencial de uso agrícola.

\subsection{Modelagem da erosão do solo na bacia hidrográfica do Ribeirão do Ceveiro}

\subsubsection{Caracterização dos fatores do modelo USLE}

O fator $\mathrm{R}$, ou fator erosividade da precipitação e da enxurrada, foi calculado como sendo de $6.273,364 \mathrm{Mj} \mathrm{ha}^{-1} \mathrm{~mm}^{-1}$, tendo sido considerado constante para toda a área da bacia (Figura 7). Este valor é intermediário, relativamente àqueles calculados pelo mesmo método, para o estado de São Paulo, conforme mapa de isoerodentes apresentado por Bertoni \& Lombardi Neto (1990). Para o estado de São Paulo, os valores da erosividade crescem do oeste para leste; os menores valores, ao redor de $5.750 \mathrm{Mj} \mathrm{ha}^{-1} \mathrm{~mm}^{-1}$, encontram-se no extremo oeste, nas regiões de Presidente Venceslau (no noroeste) e Itapeva (no sudoeste), enquanto que os maiores valores, ao redor de $8.000 \mathrm{Mj} \mathrm{ha}^{-1} \mathrm{~mm}^{-1}$, ocorrem no extremo nordeste do estado, na região de Franca. O mapa da Figura 7 corresponde ao primeiro componente ou plano de informação ( $P I_{l}$ : fator $R$ ), aplicado ao modelo USLE, no cálculo das taxas atuais de perda de solo na bacia.

O mapa do fator $\mathrm{C}$, ou fator de cobertura e manejo da cultura, para os diferentes usos da terra na bacia do Ceveiro, é apresentado na Figura 8. Quanto menor 
o valor do fator $\mathrm{C}$, maior a proteção do solo por efeito da cobertura vegetal, e viceversa. Assim, o uso com matas seria o mais protetor dos recursos do solo (fator $\mathrm{C}=$ 0,0001), enquanto que o uso com cultura anual (fator $\mathrm{C}=0,55$ ), seria o menos protetor. $\mathrm{O}$ fator $\mathrm{C}$ de 0,3066, estimado para a cana-de-açúcar (ciclo de 18 meses), é elevado por refletir a exposição do solo à época das chuvas intensas no verão. $\mathrm{O}$ mapa da Figura 8 corresponde ao segundo componente aplicado ao modelo USLE (PI $:$ fator C).

A Figura 9 mostra o mapa do fator $\mathrm{P}$, ou fator prática de controle da erosão, terceiro componente aplicado ao modelo USLE $\left(\mathrm{PI}_{3}\right.$ : fator $\left.P\right)$. O valor do fator $\mathrm{P}$ igual a 0,5 , corresponde a plantio em contorno, e foi aplicado às áreas com cultura anual e com a cultura da cana-de-açúcar. Nas áreas ocupadas com mata, reflorestamento e pastagens, considera-se que não seja aplicada qualquer prática conservacionista, o que ao fator $\mathrm{P}$ valor igual a 1,0 .

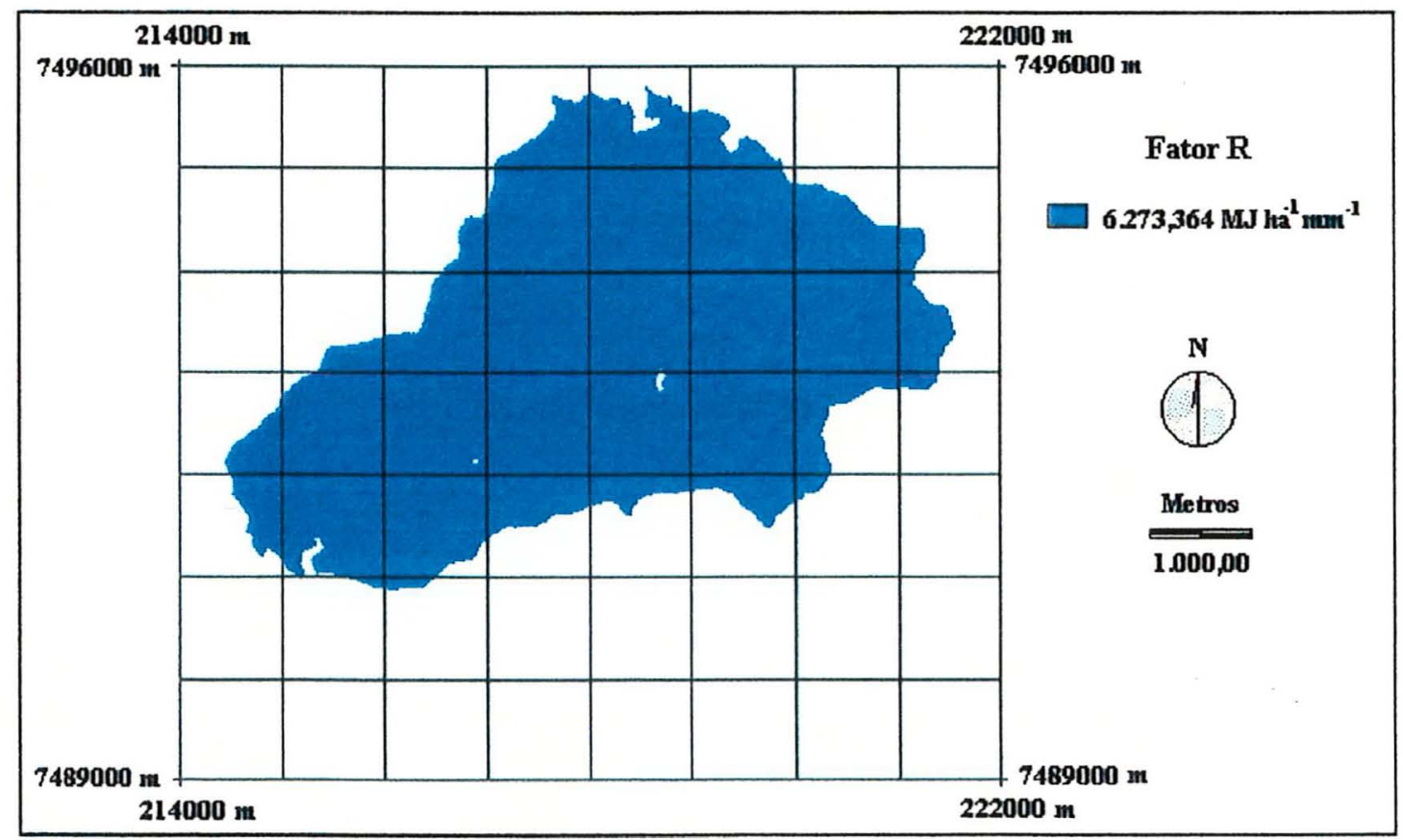

Figura 7- Fator erosividade da precipitação e da enxurrada para a bacia hidrográfica do Ribeirão do Ceveiro ( $P I_{1}:$ Mapa do fator $R$ ) 


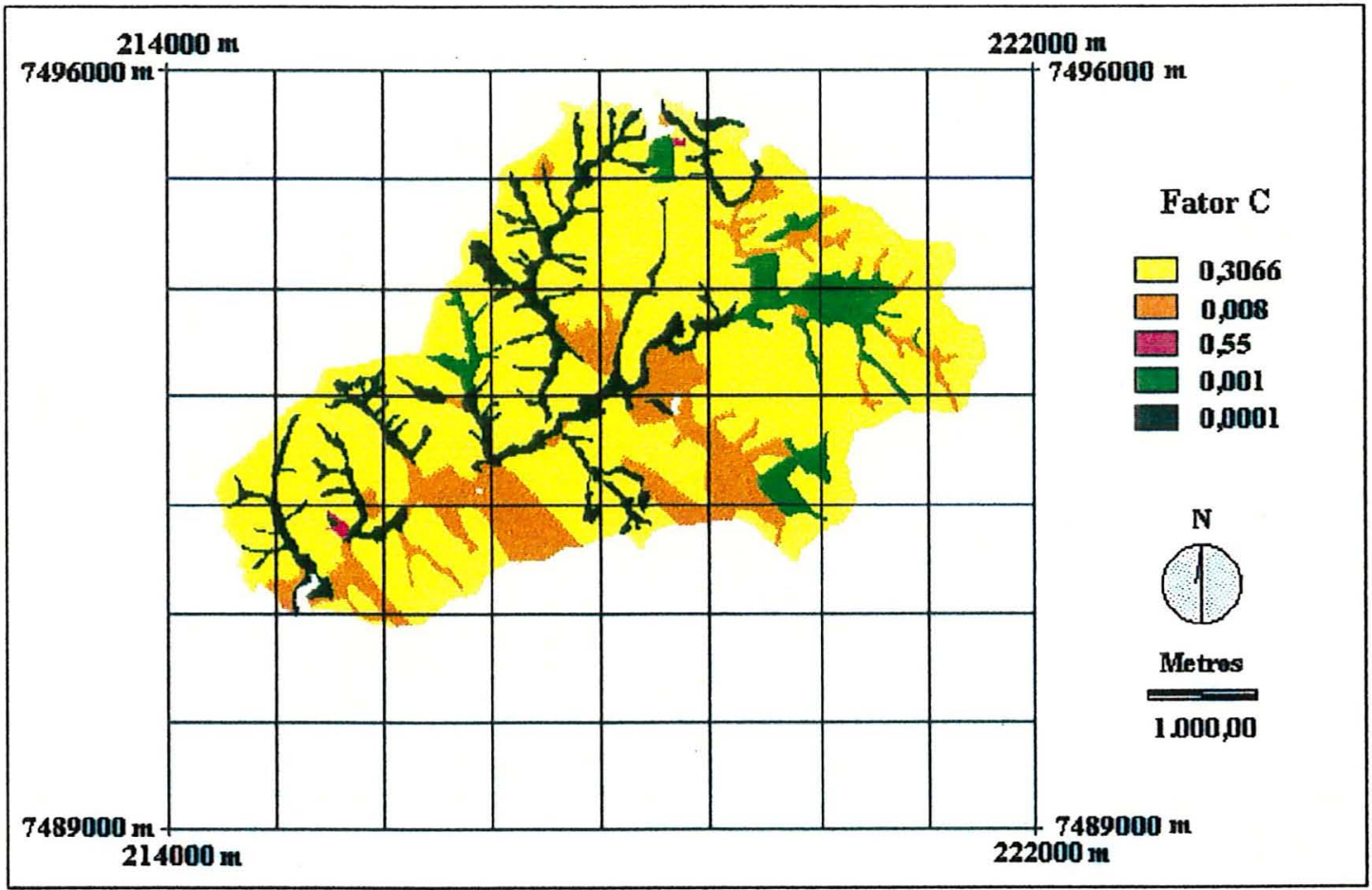

Figura 8- Fator de cobertura e manejo por categoria de uso da terra da bacia do Ribeirão do Ceveiro ( $\mathrm{PI}_{2}$ : Mapa do fator $\left.\mathrm{C}\right)$.

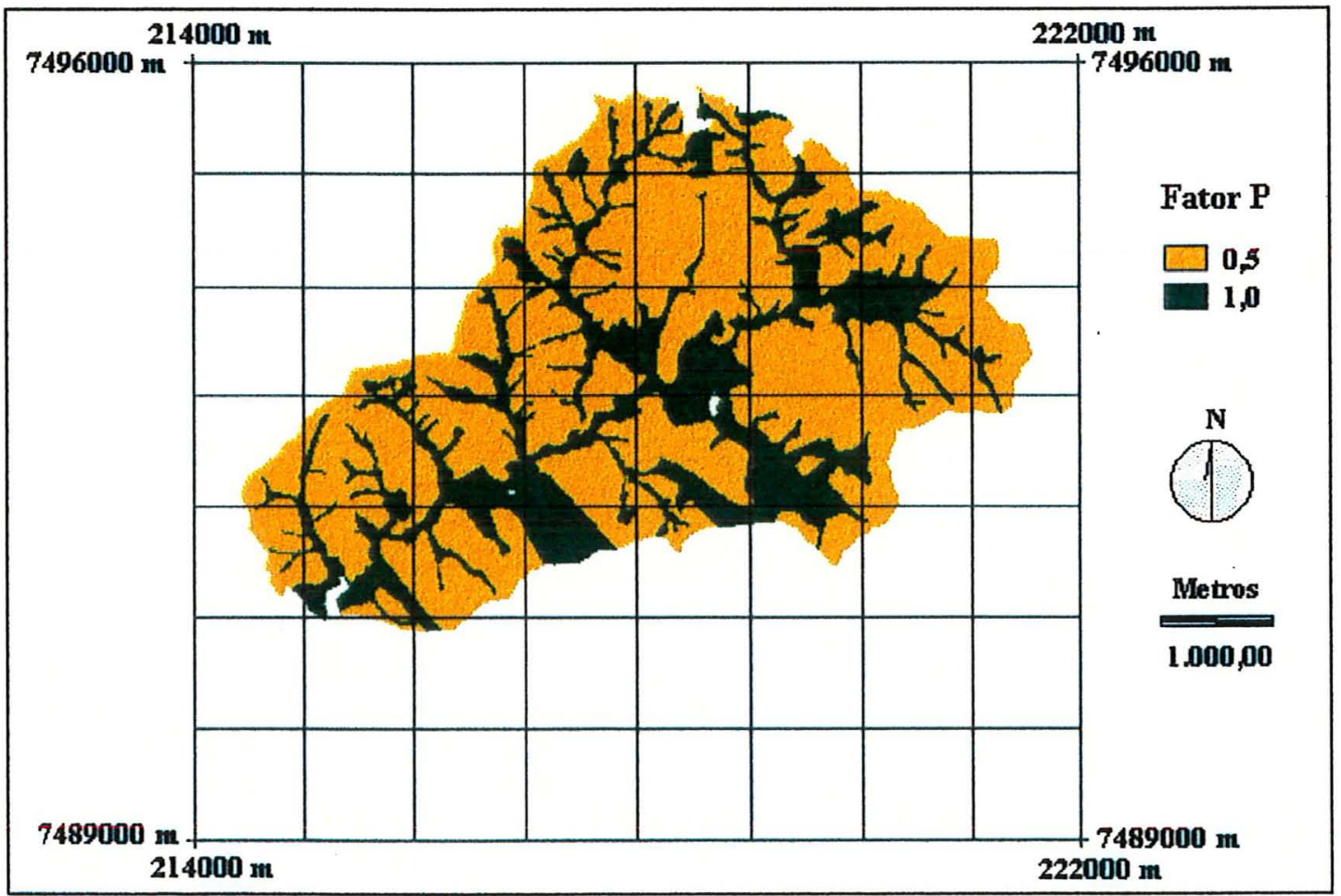

Figura 9- Fator práticas de controle da erosão para as categorias de uso da terra da bacia do Ribeirão do Ceveiro $\left(P I_{3}\right.$ : Mapa do fator $\left.P\right)$. 
À semelhança do que foi feito para a profundidade do solum, a variação da erodibilidade do solo na bacia também foi obtida por interpolação de valores estimados. Foi ajustado um semivariograma aos dados originais do tipo exponencial, sendo obtidos os parâmetros: efeito pepita $\left(\mathrm{C}_{\mathrm{o}}\right)$ igual a 0,5 ; patamar $\left(\mathrm{C}_{\mathrm{o}}\right.$ $+\mathrm{C}_{1}$ ) igual a 1,15; e, alcance (a) igual a $700 \mathrm{~m}$ ). Com estes parâmetros, os valores originais foram interpolados pelo método da krigeagem. O mapa da Figura 10 (PI fator $K$ ), resultante da interpolação, ilustra a variação da erodibilidade do solo, ou fator $\mathrm{K}$, na bacia do Ceveiro. $\mathrm{O}$ valor médio da erodibilidade do solo, ponderado em relação à área, foi de $0,0346 \mathrm{Mg} \mathrm{h} \mathrm{Mj}^{-1} \mathrm{~mm}^{-1}$, com coeficiente de variação baixo, ao redor de $11,8 \%$, e uma amplitude de variação entre os valores mínimo de $0,022873 \mathrm{Mg} \mathrm{h} \mathrm{Mj}^{-1}$ $\mathrm{mm}^{-1}$ e máximo de $0,047509 \mathrm{Mg} \mathrm{h} \mathrm{Mj}^{-1} \mathrm{~mm}^{-1}$. Em cerca de $60 \%$ da área (ou em $1.167,43 \mathrm{ha}$ ), no entanto, a faixa de variação é mais estreita, e os valores ocorrem no intervalo entre $0,033 \mathrm{Mg} \mathrm{h} \mathrm{Mj}^{-1} \mathrm{~mm}^{-1}$ e $0,039 \mathrm{Mg} \mathrm{h} \mathrm{Mj}^{-1} \mathrm{~mm}^{-1}$. Em $26 \%$ da área (505,89 ha), a erodibilidade é igual ou menor a $0,033 \mathrm{Mg} \mathrm{h} \mathrm{Mj}^{-1} \mathrm{~mm}^{-1}$; e, em $98 \%$ da área (ou em 1.906,81 ha), os valores são iguais ou menores do que $0,0428 \mathrm{Mg} \mathrm{h} \mathrm{Mj}^{-1}$ $\mathrm{mm}^{-1}$.

Os valores do fator $\mathrm{K}$, estimados para os solos da bacia do Ceveiro, estão na faixa de variação estimada para solos com gradiente textural, estabelecida entre o mínimo de $0,018 \mathrm{Mg} \mathrm{h} \mathrm{Mj}^{-1} \mathrm{~mm}^{-1}$, para a terra roxa estruturada, e o máximo de $0,055 \mathrm{Mg} \mathrm{h} \mathrm{Mj}^{-1} \mathrm{~mm}^{-1}$, para solos podzolizados com cascalho (Lombardi Neto \& Bertoni, 1975; Bertoni \& Lombardi Neto, 1990). Os valores são elevados, em comparação com aqueles estimados para os latossolos, na faixa entre $0,011 \mathrm{Mg} \mathrm{h} \mathrm{Mj}^{-1}$ $\mathrm{mm}^{-1}$ e $0,022 \mathrm{Mg} \mathrm{h} \mathrm{Mj}^{-1} \mathrm{~mm}^{-1}$, refletindo a maior susceptibilidade dos primeiros à erosão. O mapa da erodibilidade do solo (Figura 11) mostra que os maiores valores se relacionam com os solos da porção ocidental da bacia (cores avermelhadas e alaranjadas), associados ao embasamento pouco permeável representado por siltitos, argilitos e folhelhos da formação Corumbataí, que na bacia dão origem a solos litólicos, cambissolos e solos podzólicos vermelho- amarelos pouco profundos. Os menores valores, ocorrem na porção oriental da bacia (cor azul), associados a solos de textura média arenosa, alguns com horizonte A do tipo arênico, desenvolvidos a partir 


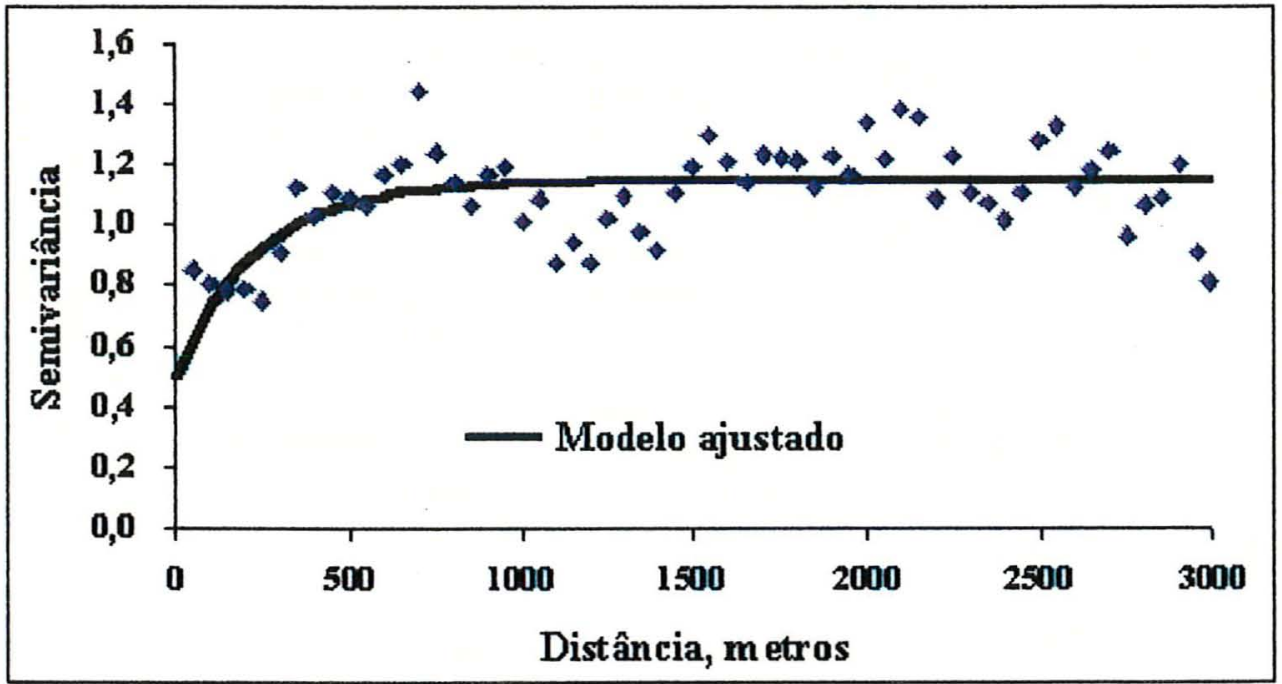

Figura 10- Semivariograma para a erodibilidade do solo na bacia do do Ribeirão do Ceveiro. Modelo exponencial: parâmetros $\left(\mathrm{C}_{\mathrm{o}}\right.$ $=0,5 ; \mathrm{C}_{1}=0,65 ; \mathrm{a}=700$ )

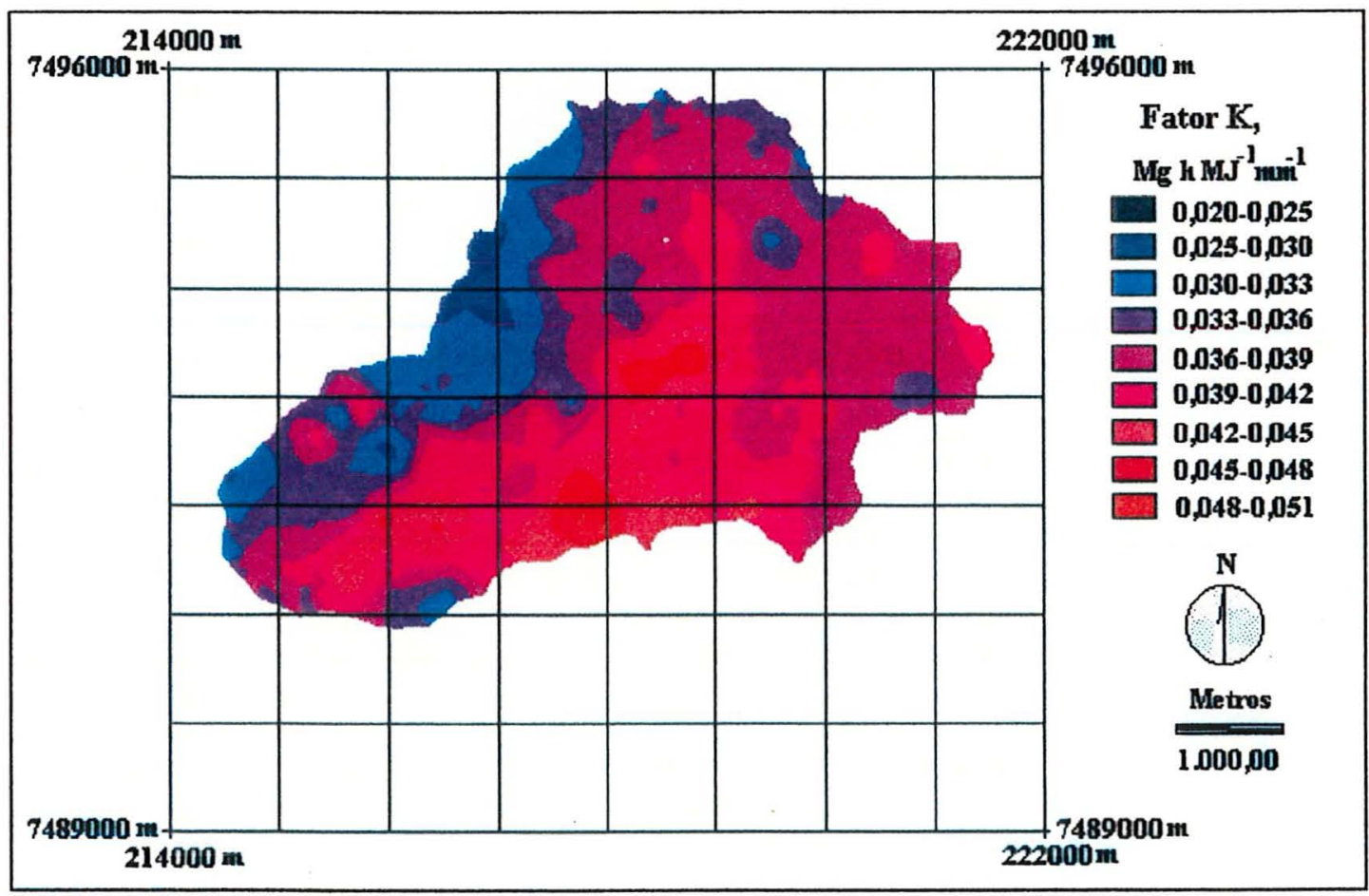

Figura 11- Fator erodibilidade dos solos para a bacia hidrográfica do Ceveiro. (PI $I_{4}$ :Mapa do fator $\left.\mathrm{K}\right)$. 
do arenito Pirambóia, que se apresentam com permeabilidade rápida e muito rápida. $\mathrm{O}$ aumento da erodibilidade ocorre, no entanto, gradualmente na bacia, sendo que predominam os valores em torno de $0,03 \mathrm{Mg} \mathrm{h} \mathrm{MJ}^{-1} \mathrm{~mm}^{-1}$.

A Figura 12 mostra o mapa do fator LS, ou fator topográfico. $\mathrm{Na}$ bacia do Ceveiro, a amplitude de variação do fator LS é grande, indo desde praticamente zero até o valor máximo de 9,877. Em 51,46\% da área (ou em 1.001,27 ha), no entanto, o fator LS é igual ou inferior a 1,5999. O valor médio, ponderado pela área, é de $1,8058(\mathrm{CV}=56,37 \%)$. Para compreensão do significado desses valores, 1,6 e 1,8, faz-se a análise, a seguir, da variação do comprimento da vertente e da declividade, componentes principais que entraram no cálculo do fator topográfico, conforme a expressão 9 (Seção 3.6.3).

Nas áreas de não cana-de-açúcar, o comprimento médio da vertente, ponderado em relação à área, foi de $58,37 \mathrm{~m}(\mathrm{CV}=99,52 \%)$, muito semelhante à média obtida para as áreas com cana-de-açúcar, de $60,44 \mathrm{~m}(\mathrm{CV}=68,67 \%)$, o que caracteriza um comprimento de vertente médio para a bacia de cerca de $60 \mathrm{~m}(\mathrm{CV}=$ $71,86 \%)$. Para $34,67 \%(217,03 \mathrm{ha})$ das áreas de não cana-de-açúcar, foram calculados comprimentos de até $20 \mathrm{~m}$; em $57 \%(356,87$ ha), os comprimentos são iguais ou inferiores a $40 \mathrm{~m}$; e em $90,33 \%$ (565,64 ha), iguais ou inferiores a $130 \mathrm{~m}$. Nas áreas de cana-de-açúcar, as maiores ocorrências se relacionam aos comprimentos entre 30 e $40 \mathrm{~m}(536,56 \mathrm{ha}$, equivalentes a $40,66 \%)$, de $70 \mathrm{~m}(521,24$ ha ou $39,5 \%)$, e de $140 \mathrm{~m}(141,84$ ha ou $10,75 \%)$, que em conjunto representam cerca de $91 \%$ da área total da categoria. Esses dados revelam a faixa entre 20 e $40 \mathrm{~m}$ como sendo a de maior ocorrência na bacia. Quanto à declividade, os valores médios, ponderados em relação às áreas com cana-de-açúcar e não cana-de-açúcar, foram muito semelhantes, e respectivamente de $10,63 \%(\mathrm{CV}=52,61 \%)$ e $10,74 \%(\mathrm{CV}=65,15 \%)$, o que caracteriza uma declividade média ponderada para a bacia como um todo, em torno de $10,70 \%$. Nas áreas de não cana-de-açúcar, a declividade é igual ou inferior a $6 \% \mathrm{em}$ cerca de 141,49 ha $(22,6 \%)$, contra 181,44 ha $(13,75 \%)$ das áreas de cana-de-açúcar; as declividades vão até $10 \%$ em $51,56 \%$ das áreas de não cana-de-açúcar $(322,81$ ha), contra 54,77\% das áreas com cana-de-açúcar (722,77ha); declividades até $14 \%$, ocorrem em 76,41\% da área de não cana (478,39 ha), contra 80,39\% nas áreas de cana $(1.060,86 \mathrm{ha})$; e declividades iguais ou inferiores a $20 \%$, ocorrem em $93,62 \%$ 
da área de não cana (586,14 ha), contra 96,1\% nas áreas de cana (1268,17 ha). O padrão de distribuição dos valores da declividade também é, portanto, semelhante para as duas categorias de uso.

A análise precedente caracterizou para a bacia um valor médio de comprimento de vertente, em torno de $60 \mathrm{~m}$ e uma declividade média em torno de $10,7 \%$. Aplicando esses valores à expressão 6 , obtém-se o valor de 2,12 para o fator LS. Caso se diminua o comprimento da vertente para $35 \mathrm{~m}$, um valor dentro da faixa de ocorrência mais freqüente, o fator LS calculado pela expressão 6 cai para 1,52. Pequenas variações nessas combinações de comprimento de vertente e declividade, explicam os valores encontrados do fator LS, de 1,81 e 1,59, indicados no parágrafo inicial. O mapa da Figura 12 representa o quinto componente aplicado ao modelo USLE, após o ajuste para a bacia do Ceveiro ( $P I_{5}$ : fator $\left.L S\right)$.

Caracterizada a variação dos cinco componentes do modelo USLE na bacia do Ceveiro, o modelo foi aplicado, sendo estimadas as taxas atuais de perda de solo, o que é relatado a seguir.

\subsubsection{Perda de solo na bacia do Ribeirão do Ceveiro}

O estudo da erosão acelerada em dado local, inicia com algum tipo de estimativa acerca da extensão e taxas de ocorrência do processo (Schertz, 1983). $\mathrm{Na}$ bacia do Ceveiro, a caracterização da erosão presente, ocorreu pela aplicação do modelo USLE, que permitiu estimar as taxas atuais de perda de solo, basicamente associadas com a erosão entre-sulcos e em sulcos pequenos. Os resultados são inicialmente apresentados separadamente para as áreas de não cana-de-açúcar e de cana-de-açúcar. Posteriormente, foram os mesmos consolidados, para a bacia como um todo.

Para a categoria não cana-de-açúcar, que engloba 626,08 ha, ou cerca de $32,18 \%$ da área total avaliada, ocupada predominantemente com pastagens, mata e reflorestamento, as taxas atuais de perda de solo estimadas são baixas: para cerca de metade da área (313,98 ha), as perdas são inferiores a $0,44 \mathrm{Mg} \mathrm{ha}^{-1}$ ano ${ }^{-1}$; as 


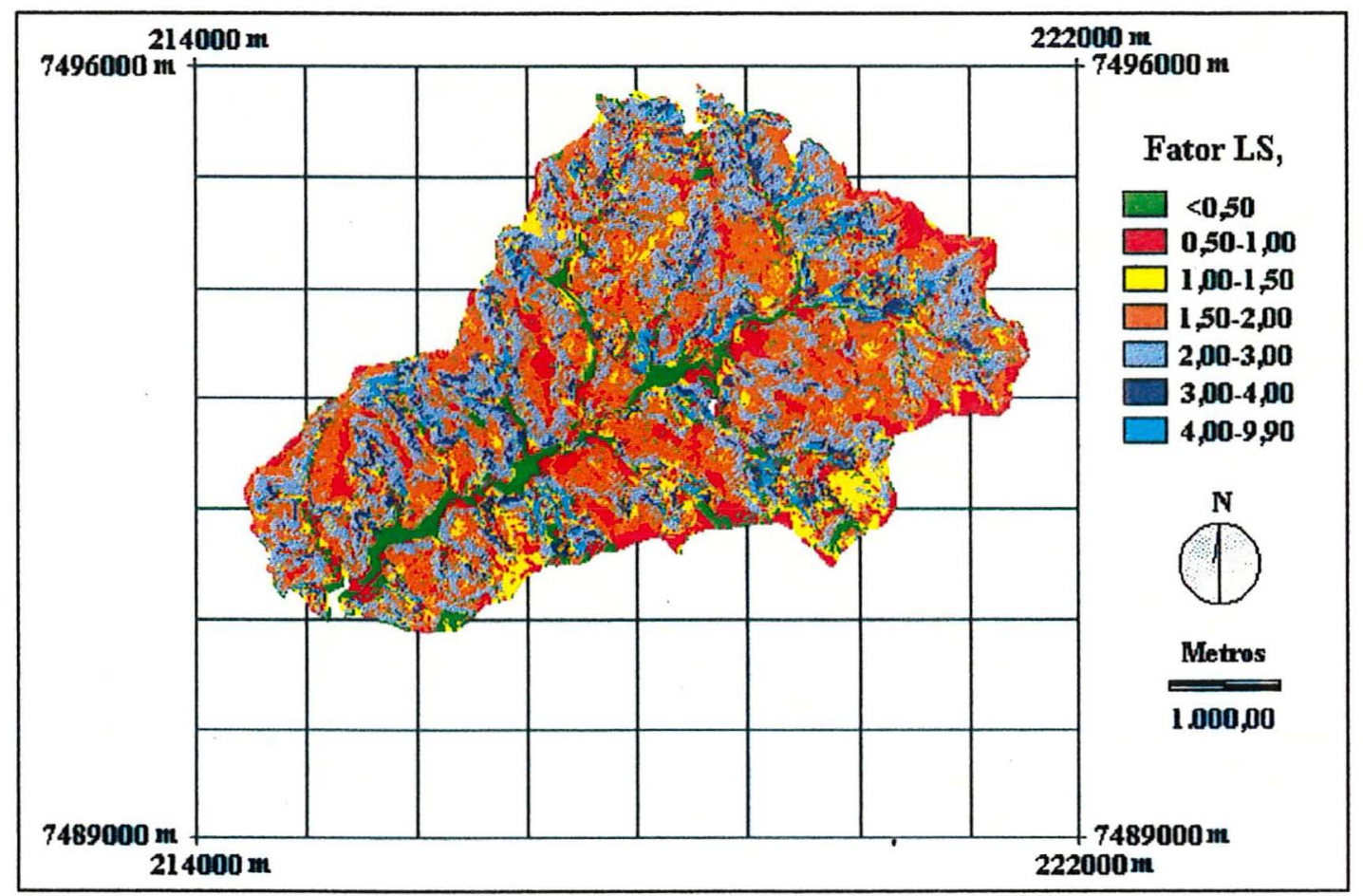

Figura 12- Fator topográfico para a bacia hidrográfica do Ribeirão do Ceveiro (PI5: Mapa do fator LS).

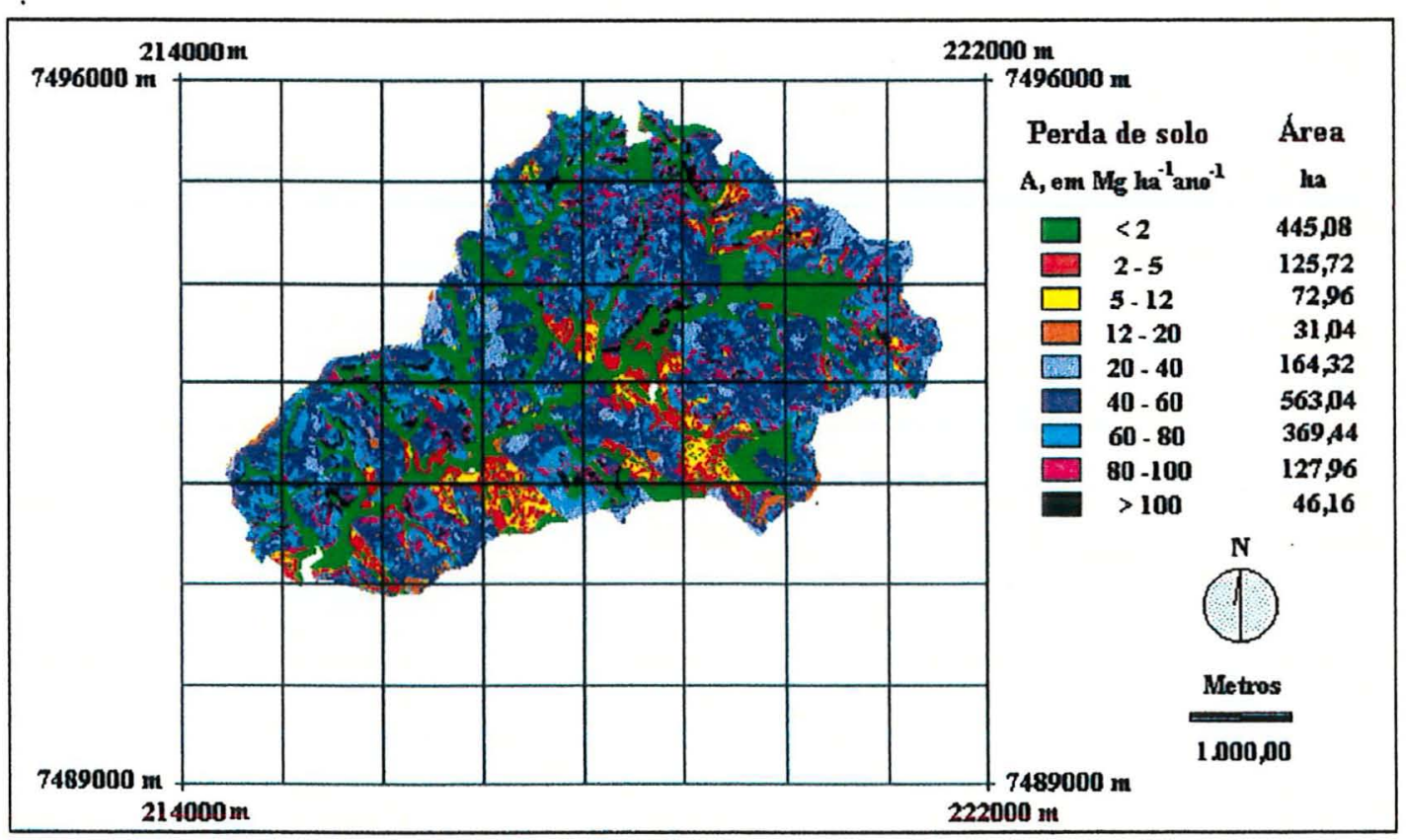

Figura 13- Taxas estimadas de perda de solo na bacia hidrográfica do Ceveiro (A, em Mg ha ${ }^{-1}$ ano $^{-1}$ ) e ocorrência (área, em hectares) 
em $89,55 \%$ da área, as perdas são inferiores a $5,00 \mathrm{Mg} \mathrm{ha}^{-1}$ ano ${ }^{-1}$; e, em $99,37 \%$ perdas são inferiores a $12,00 \mathrm{Mg} \mathrm{ha}^{-1}$ ano $^{-1}$. A perda média calculada para a categoria de usos menos intensivos, ponderada em relação à área, é de apenas $2,2 \mathrm{Mg} \mathrm{ha}^{-1} \mathrm{ano}^{-1}$, muito embora, o coeficiente de variação seja elevado, da ordem de 430,84\%. Eliminando os 64 valores mais altos, que ocorrem em uma área de apenas 2,56 ha, onde as perdas de solo superam a taxa de $25,00 \mathrm{Mg} \mathrm{ha}^{-1}$ ano ${ }^{-1}$ (perdas associadas com a pequena proporção da categoria ocupada com cultura anual), a perda média cai para $1,7 \mathrm{Mg} \mathrm{ha}{ }^{-1}$ ano $^{-1}(\mathrm{CV}=148,97 \%)$. A Tabela 8 traz um resumo dos dados apresentados anteriormente.

Tabela 8- Perda de solo estimada $\left(A, \mathrm{Mg} \mathrm{ha}^{-1}\right.$ ano $\left.^{-1}\right)$ nas áreas de não cana-de-açúcar da bacia do Ceveiro e área de ocorrência.

\begin{tabular}{ccc}
\hline $\boldsymbol{A}$ (não cana), até & \multicolumn{2}{c}{ Ocorrência } \\
\hline $\mathbf{M g ~ h a}^{-1} \mathbf{~ a n o ~}^{-1}$ & ha & $\%$ \\
0,5 & 313,99 & 50,15 \\
5,00 & 560,65 & 89,55 \\
10,00 & 615,62 & 98,33 \\
12,00 & 622,14 & 99,37 \\
\hline
\end{tabular}

Na porção da bacia ocupada com a cultura da cana-de-açúcar, ou em $1.319,64$ ha $(67,82 \%$ da área total avaliada de $1.945,72$ ha), foi estimada uma perda média, ponderada em relação à área, elevada, de cerca de $57,90 \mathrm{Mg} \mathrm{ha}^{-1} \mathrm{ano}^{-1}$. O coeficiente de variação é relativamente baixo, no valor de $36,98 \%$, conferindo consistência à média. A Tabela 9 relaciona as taxas estimadas de erosão em relação à área acumulada. Os resultados indicam que as taxas atuais de perda de solo, estimadas pela USLE, são inferiores a $12,0 \mathrm{Mg} \mathrm{ha}^{-1} \mathrm{ano}^{-1}$ em apenas $1,65 \%$ da área com canade-açúcar, o que engloba parcos 21,77 ha. Para cerca de $50 \%$ da área com cana-deaçúcar $(659,82 \mathrm{ha})$, as perdas superam a taxa de $55,0 \mathrm{Mg} \mathrm{ha}^{-1} \mathrm{ano}^{-1}$, e para $10 \%$ da área (131,96 ha), as perdas são muito elevadas, maiores do que $83,6 \mathrm{Mg} \mathrm{ha}^{-1} \mathrm{ano}^{-1}$.

Computando estes dados para a bacia do Ceveiro como um todo, as perdas de solo estimadas refletem uma situação naturalmente intermediária, em relação às duas categorias principais apresentadas anteriormente. A Figura 13 ilustra a 
distribuição das taxas de perda de solo, classificada em nove intervalos, entre $2 \mathrm{Mg}$ $\mathrm{ha}^{-1} \mathrm{ano}^{-1}$ e $100 \mathrm{Mg} \mathrm{ha}^{-1} \mathrm{ano}^{-1}$.

Tabela 9- Perda de solo estimada ( $\left.\mathrm{A}, \mathrm{Mg} \mathrm{ha}^{-1} \mathrm{ano}^{-1}\right)$ nas áreas de cana-de-açúcar da bacia do Ceveiro e área de ocorrência.

\begin{tabular}{ccc}
\hline A, Cana até & \multicolumn{2}{c}{ Ocorrência } \\
\hline Mg ha $^{-1}$ ano $^{-1}$ & ha & $\%$ \\
5,0 & 10,56 & 0,80 \\
10,0 & 16,50 & 1,25 \\
12,0 & 21,77 & 1,65 \\
55,1 & 659,95 & 50,01 \\
83,58 & 1187,68 & 90,00 \\
\hline
\end{tabular}

Predominam na bacia, taxas estimadas de perda de solo na faixa entre $40 \mathrm{Mg} \mathrm{ha}^{-1}$ ano ${ }^{-1}$ e $80 \mathrm{Mg} \mathrm{ha}^{-1}$ ano $^{-1}$, que em conjunto representam cerca de $932,48 \mathrm{ha}$, ou $47,9 \%$ da área total avaliada de $1.945,72$ ha. As perdas inferiores a $2,00 \mathrm{Mg} \mathrm{ha}^{-1}$ ano $^{-1}$ também constituem ocorrência importante, de cerca de 445,08 ha, correspondentes a 22,9 \% da área total, associada com os usos menos intensivos. A taxa média de perda de solo, ponderada em relação à área total, é de cerca de $40 \mathrm{Mg} \mathrm{ha}^{-1}$ ano $^{-1}$. O coeficiente de variação, no valor de $79,78 \%$, é elevado. A Tabela 10 relaciona alguns dados sobre perda estimada ( $\mathrm{A}, \mathrm{em} \mathrm{Mg} \mathrm{ha}^{-1}$ ano ${ }^{-1}$ ) e área acumulada (em ha e em \%).

Tabela 10- Perda de solo estimada $\left(\mathrm{A}, \mathrm{Mg} \mathrm{ha}^{-1} \mathrm{ano}^{-1}\right)$ na bacia do Ceveiro e área de ocorrência.

\begin{tabular}{ccc}
\hline $\mathbf{A}$, Ceveiro até & \multicolumn{2}{c}{ Ocorrência } \\
\hline $\mathbf{M g ~ h a}^{-1} \mathbf{a n o}^{-1}$ & $\mathbf{H a}$ & $\%$ \\
5,0 & 571,20 & 29,36 \\
10,0 & 632,16 & 32,49 \\
12,0 & 643,84 & 33,09 \\
48,8 & 972,86 & 50,00 \\
78,6 & 1751,15 & 90,00 \\
\hline
\end{tabular}


4.3.3 Influência dos fatores da USLE, nas taxas estimadas de perda de solo na bacia do Ceveiro

A USLE, modelo adotado para estimativa das perdas de solo por erosão no Ceveiro, é um modelo multiplicativo simples, isto é, todos os fatores entram no modelo com o mesmo peso e detém o mesmo grau de importância. No entanto, a amplitude de variação de cada fator na bacia, influencia de forma diferenciada a estimativa da erosão.

Por exemplo o fator $\mathrm{R}$, ou fator erosividade da precipitação e da enxurrada, que foi considerado constante para toda a área da bacia, não se relaciona com a variação observada nas taxas estimadas de perda de solo na área.

A principal fonte de variação, relativamente à ordem de grandeza das taxas estimadas, relaciona-se com o uso e manejo das terras, que é expresso no modelo pelos fatores $\mathrm{C}$, fator de cobertura e manejo da cultura, e $\mathrm{P}$, fator prática de controle da erosão, conforme será visto mais adiante.

Dentro de uma mesma categoria de uso (fatores $\mathrm{C}$ e $\mathrm{P}$, constantes), as variações estimadas se relacionam com a variação das condições do solo e do terreno, expressas no modelo pelos fatores K (fator erodibilidade do solo) e LS (fator topográfico).

O efeito do uso e manejo das terras foi avaliado através de testes de médias das taxas estimadas de erosão por categoria de uso da terra. Os resultados dos testes de médias mostraram que a perda média de solo estimada nas áreas com cultura anual $\left(113,50 \mathrm{Mg} \mathrm{ha}^{-1}\right.$ ano $\left.^{-1}\right)$ é superior, e significativamente diferente, ao nível de 5 $\%$ de probabilidade pelo teste $\mathrm{T}$, da perda de solo estimada em todas as outras seis categorias de uso. A perda média estimada para as áreas com cana-de-açúcar $(57,90$ $\mathrm{Mg} \mathrm{ha}^{-1}$ ano $^{-1}$ ), também é significativamente diferente das perdas médias estimadas para todos os demais usos da terra, sendo superior em relação aos usos menos intensivos, representados por pastagens $\left(3,5 \mathrm{Mg} \mathrm{ha}^{-1}\right.$ ano $\left.^{-1}\right)$, mata $\left(0,03 \mathrm{Mg} \mathrm{ha}^{-1}\right.$ $\left.a^{-1}\right)$ e reflorestamento $\left(0,46 \mathrm{Mg} \mathrm{ha}^{-1} a^{-1}\right)$, e inferior em relação ao uso mais intensivo, representado pela cultura anual. As perdas de solo nas áreas utilizadas com pastagens, superam e são significativamente diferentes, das perdas estimadas para as áreas de mata e reflorestamento, muito embora a diferença entre as médias $(3,3884$; $3,8085 ; 3,8140)$ seja próxima da diferença mínima significativa $(2,4299,2,8725$, 
2,7903), respectivamente para reflorestamento, mata e vegetação ciliar. Não ocorrem diferenças significativas entre as perdas estimadas para as áreas de reflorestamento, mata e vegetação ciliar.

Como já comentado, à medida em que os fatores $\mathrm{C}$ e $\mathrm{P}$ são constantes por categoria de uso, a variação das taxas de perda de solo em uma mesma categoria, é explicada pela variação dos fatores LS (fator topográfico) e K (fator erodibilidade do solo). A influência dos fatores LS e K sobre as taxas de perda de solo estimadas, foi avaliada pela análise de gráficos de dispersão.

Para o fator LS, a análise de dispersão discriminou claramente quatro grupos de dados, designados por (1), (2), (3) e (4), na Figura 14. É claramente perceptível na Figura 14, que para os grupos (1), (2) e (3), a perda de solo se relaciona diretamente com o Fator LS, sendo que aparentemente para o grupo (4), este fator pouco influência nas perdas estimadas, que se mantém muito baixas, praticamente nulas, em toda a faixa de variação do Fator LS. Já com os resultados dos testes de médias, apresentados anteriormente, pode ser interpretado que os grupos (1) e (2), os que detém as taxas de perda mais elevadas, representam, respectivamente, as áreas da bacia ocupadas com cultura anual e com cana-de-açúcar, assim como, os grupos (3) e (4) podem ser interpretados como representando as perdas nas áreas com pastagens (3) e com mata e reflorestamento (4). Quando se fez os gráficos de dispersão entre as perdas estimadas e a variação do fator LS, separadamente para cada categoria de uso, obteve-se sempre, mesmo para reflorestamento e mata (grupo 4), uma relação direta e positiva, isto é, o aumento do fator LS, promoveu aumentos proporcionais nas taxas estimadas de perda de solo, para todos os tipos de uso avaliados. Para os usos mais intensivos (grupos 1 e 2), a variação do fator LS promoveu uma ampla variação nas taxas estimadas de perda de solo.

De modo semelhante, foi investigado o efeito do fator $\mathrm{K}$ sobre as taxas estimadas de perda de solo. Conforme pode ser observado na Figura 15, há uma grande dispersão dos dados, que mascara o efeito da erodibilidade do solo nas perdas 


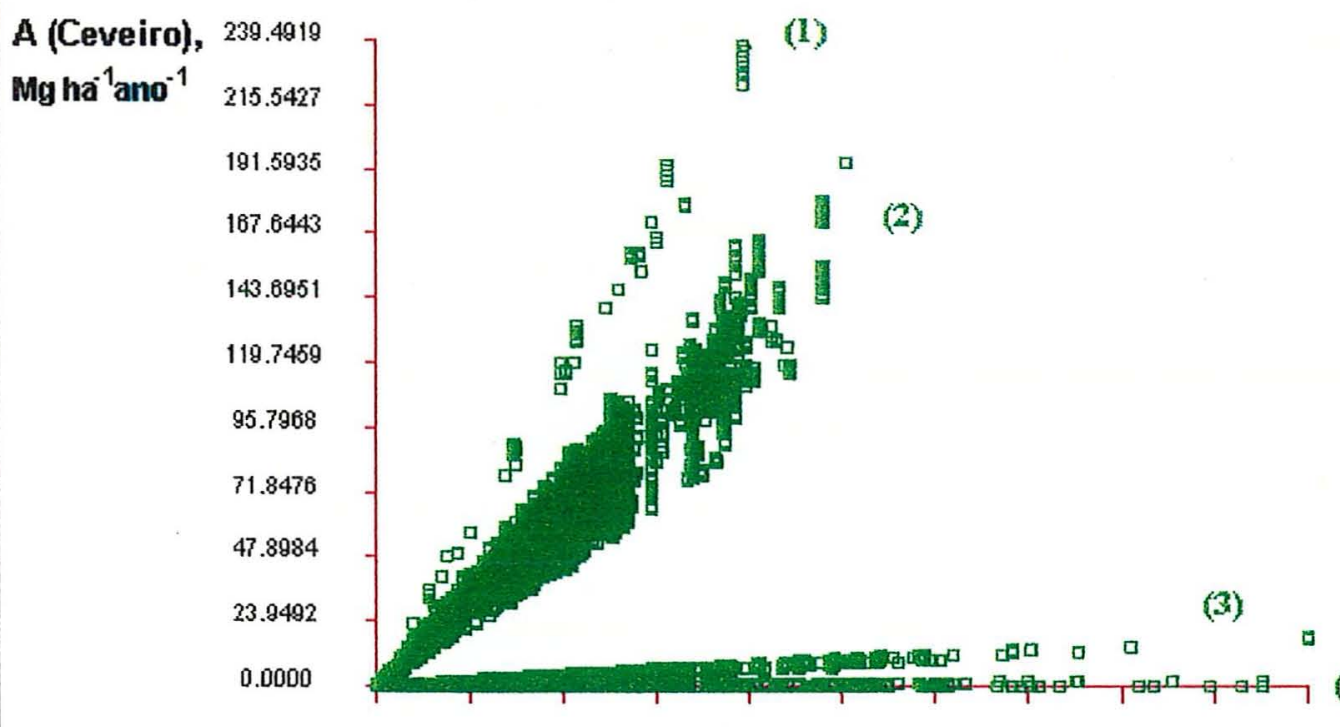

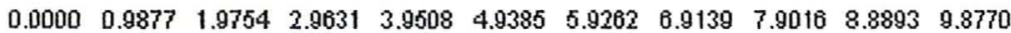

Fator LS

Figura 14- Gráfico de dispersão da perda de solo na bạcia do Ceveiro em relação à variação do fator LS.

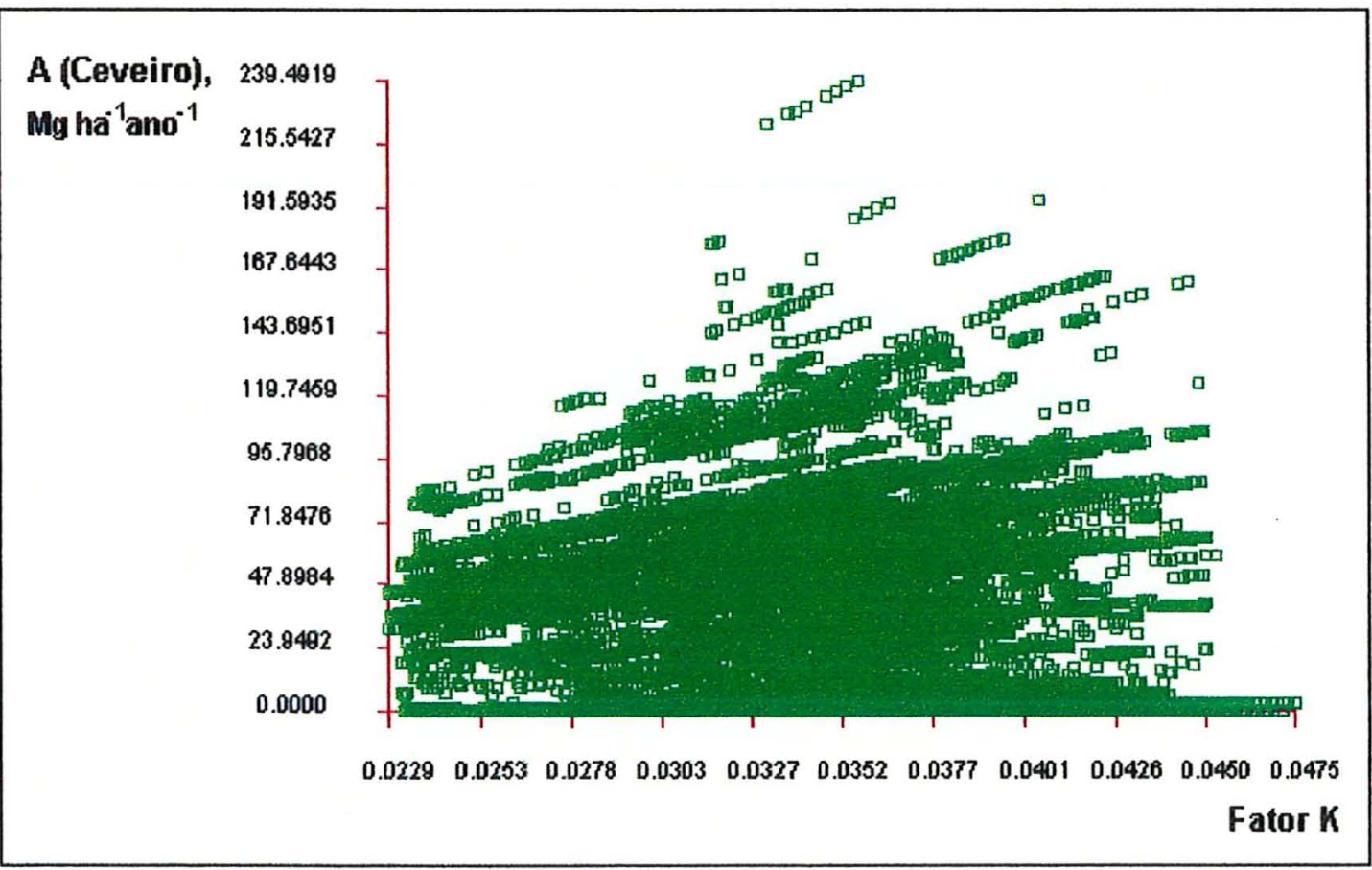

Figura 15- Gráfico de dispersão da perda de solo na bacia do Ceveiro em relação à variação do fator $\mathrm{K}$. 
estimadas. Há uma tendência de aumento das taxas de erosão, em função do aumento da erodibilidade mas, diferente do que foi observado em relação ao fator LS, a distribuição não mostra um padrão inequívoco. Esse mesmo tipo de distribuição randômica foi encontrado, quando se fez a dispersão considerando separadamente cada categoria de uso da terra. A erodibilidade dos solos, na bacia do Ceveiro, varia em uma faixa estreita, entre $0,0229 \mathrm{Mg} \mathrm{h} \mathrm{MJ}^{-1} \mathrm{~mm}^{-1}$ e $0,04750,0229 \mathrm{Mg} \mathrm{h} \mathrm{MJ}^{-1} \mathrm{~mm}^{-1}$. Muito embora os valores cresçam da porção oriental da bacia, onde ocorrem os solos mais permeáveis, para a porção ocidental, de ocorrência dos solos mais rasos e de substrato pouco permeável (cf. Figura 11), esse crescimento é muito gradual. Essa ausência de transições claras, parece influenciar as estimativas de maneira uniforme e progressiva, independentemente do tipo de uso, o que explicaria a ausência de um tendência clara na distribuição dos dados.

Os resultados obtidos pela análise dos fatores $\mathrm{LS}$ e $\mathrm{K}$, não permitem concluir que as taxas estimadas para os usos menos intensivos, em torno de $2,0 \mathrm{Mg}$ $\mathrm{ha}^{-1}$ ano $^{-1}$, um valor muito baixo, estejam relacionadas com a localização desses usos em solos menos susceptíveis à erosão (ou de baixa erodibidade), ou em áreas pouco acidentadas da bacia, uma vez que as perdas se mantém baixas em toda a faixa de variação do fator LS, conforme observado na Figura 14, para os grupos (3) e (4)). O raciocínio oposto também é valido. A grande dispersão dos dados, observada no gráfico da Figura 15, também não permite relacionar as elevadas taxas estimadas de perda de solo na cultura anual (perda média de $113,50 \mathrm{Mg} \mathrm{ha}^{-1}$ ano $^{-1}$ ) e na cana-deaçúcar (perda média de $57,90 \mathrm{Mg} \mathrm{ha}^{-1}$ ano $^{-1}$ ), com a instalação desses usos sobre solos de alta erodibilidade. Os resultados obtidos corroboram para a interpretação já manifesta de que a ordem de grandeza das estimativas, isto é, se as perdas giram em torno de 1 , de 10 , de 50 ou de $100 \mathrm{Mg} \mathrm{ha}^{-1}$ ano $^{-1}$, é uma função basicamente do tipo de uso e manejo adotado, cujo efeito é expresso no modelo através dos fatores $\mathrm{C}$ e $\mathrm{P}$.

\subsubsection{Simulação do efeito alternado dos fatores LS e K}

Para "quantificar" a influência dos fatores LS e K, foi efetuada uma simulação: foi fixado o valor de LS pela média, e calculada a perda para o $\mathrm{K}_{\text {min. }}$ e para o $\mathrm{K}_{\text {max., }}$ e vice-versa, foi fixado o valor de $\mathrm{K}$, e calculada a perda para o LS min. $_{\text {. }}$ para o LS máx. O objetivo da análise foi caracterizar a amplitude de 
variação das taxas estimadas, em função da variação de LS e K. A análise foi efetuada apenas para o uso com a cultura da cana-de-açúcar.

No Ceveiro, nas áreas com cana-de-açúcar, o produto dos fatores $\mathrm{R}, \mathrm{C}$ e $\mathrm{P}$ (constantes) é igual a $961,7067 \mathrm{Mj} \mathrm{mm} \mathrm{ha}{ }^{-1} \mathrm{~h}^{-1}$. Fixando o fator LS em 1,7735 , valor médio relativo às áreas de cana-de-açúcar, estimou-se uma perda de $39,0 \mathrm{Mg} \mathrm{ha}^{-1}$ ano $^{-1}$, considerando o valor mínimo do fator $\mathrm{K}\left(\mathrm{K}_{\min }=0,0229 \mathrm{Mg}\right.$ $\mathrm{h} \mathrm{MJ}^{-1} \mathrm{~mm}^{-1}$ ), e uma perda de $81,0 \mathrm{Mg} \mathrm{ha}^{-1}$ ano ${ }^{-1}$, quando se considerou o valor máximo do fator $\mathrm{K}\left(\mathrm{K}_{\text {max }}=0,0476 \mathrm{Mg} \mathrm{h} \mathrm{MJ}^{-1} \mathrm{~mm}^{-1}\right)$, o que caracteriza uma relação entre a perda mínima e a máxima de $1: 2$. Isto é, na faixa de variação do fator $\mathrm{K}$ nas áreas com cana-de-açúcar da bacia do Ceveiro, as perdas podem dobrar, quando se passa do valor mínimo para o valor máximo da erodibilidade do solo, mantidos constantes os demais fatores. Significa que erros na estimativa da erodibilidade do solo, ou do fator $\mathrm{K}$, podem resultar em erros de estimativa das taxas de erosão de até duas vezes para mais ou para menos.

Pelo procedimento inverso, fixando o fator $\mathrm{K}$ pela média $\left(\mathrm{K}_{\text {med. }}=\right.$ $0,0342 \mathrm{Mg} \mathrm{h} \mathrm{MJ}^{-1} \mathrm{~mm}^{-1}$, nas áreas com cana-de-açúcar), a perda calculada considerando o valor mínimo do fator LS nestas áreas $\left(L_{\min }=0,01958\right.$ ), foi de $0,64 \mathrm{Mg} \mathrm{ha}^{-1}$ ano ${ }^{-1}$, e a perda considerando o valor máximo do fator LS (LS máx. $=4,97735$ ) foi de $163,71 \mathrm{Mg} \mathrm{ha}^{-1}$ ano ${ }^{-1}$, o que dá uma relação entre as perdas mínima e máxima de $1: 254$. Isto é, na faixa de variação do fator LS nas áreas com cana-de-açúcar da bacia do Ceveiro, as perdas podem ser até 254 vezes maiores do que a perda mínima, mantidos os demais fatores constantes. Significa uma possibilidade de erro nas estimativas das perdas de até 254 vezes para mais ou para menos, em função de erro nas estimativas do fator LS.

A partir dessa simulação, pode-se concluir que o efeito da variação do fator LS, sobre as taxas estimadas de perda de solo na bacia do Ceveiro, foi muito mais acentuado, comparado com aquele devido à variação da erodibilidade do solo ou fator K. Quando se aplica o modelo USLE em bacias hidrográficas e, sobretudo, quando o modelo é aplicado dentro de um SIG, a maior dificuldade provavelmente resida no cálculo do comprimento da vertente e, por conseguinte, no cálculo da fator LS. O procedimento automatizado, que é uma das vantagens de se trabalhar com o SIG, pode se constituir em uma fonte de imprecisão ou de erro não controlável, em um 
fator muito significativo. Os resultados obtidos recomendam que mais tempo e recursos devem ser destinados para o aperfeiçoamento metodológico, contando-se com a vantagem de que o trabalho de campo é muito menos intensivo, relativamente a outras etapas da modelagem, o que propicia economia de tempo e recursos.

Os resultados obtidos para o fator $\mathrm{K}$, também merecem considerações adicionais. Em primeiro lugar, há que se destacar que a determinação da erodibilidade do solo constitui uma etapa cara e morosa dentro do processo de estimativa da erosão. Numerosos modelos tem sido desenvolvidos, buscando estimar o parâmetro a partir de atributos determinados em laboratório, por serem de mais fácil obtenção, quando comparado à determinação direta da erodibilidade no campo, com uso de simuladores de chuva ou de chuva natural. Recentemente, Marques et al. (1997) compararam treze modelos para estimativa indireta da erodibilidade do solo. A equação desenvolvida por Denardin (1990), utilizada neste trabalho, é um dos modelos analisados. Ainda assim, a estimativa indireta do parâmetro demanda trabalho de campo para coleta de amostras e análises laboratoriais. Apesar do intenso trabalho de campo, de laboratório e de processamento dos dados para estimativa indireta da erodibilidade dos solos do Ceveiro, os valores obtidos caíram dentro da faixa de variação estimada por Lombardi Neto \& Bertoni (1975) para solos correlatos do estado de São Paulo, ao nível de grande grupo. À despeito inclusive de terem sido usados métodos distintos para estimativa do parâmetro em cada caso. Esses resultados sinalizam que deve ser investigada a possibilidade de simplificação das estimativas futuras, por economia de recursos e de tempo.

A modelagem da erosão na bacia do Ceveiro revelou que, para uma mesma condição climática (fator $\mathrm{R}$ constante), o fator que definiu a ordem de grandeza das perdas estimadas pela USLE, foi o fator $\mathrm{C}$, ou fator uso e manejo das terras. $\mathrm{O}$ segundo fator que mais influenciou a variação das taxas atuais de erosão estimadas foi o fator topográfico ou fator LS. A influência da erodibilidade do solo (fator K) nas taxas estimadas de erosão não seguiu um padrão consistente, não permitindo definir uma tendência geral para explicar a variação observada.

Conforme já comentado na revisão de literatura, a USLE foi criada com o objetivo de estimar a perda anual de solo decorrente da erosão entre-sulcos e em pequenos sulcos, considerando uma gleba homogênea (grau de declividade e de 
orientação da vertente constantes) (Wischmeier \& Smith, 1965; 1978) Aplicada em uma microbacia hidrográfica, decorrem limitações relacionadas com o fenômeno de deposição nas encostas, não contemplado pelo modelo. Há uma tendência de superestimação da perda de solo, uma vez que nem toda a terra que é mobilizada deixa a microbacia. A equação não estima depósitos, nem a produção de sedimentos. No entanto, tomando-se o cuidado de ajustar criteriosamente os fatores do modelo à realidade local, as taxas estimadas de perda de solo indicam a variação da intensidade do processo localmente. $\mathrm{E}$, ainda, se $o$ fator $\mathrm{C}$ foi convenientemente estimado, a ordem de grandeza das estimativas, é uma informação válida e fundamental ao trabalho de planejamento.

\subsection{Interpretação dos resultados da modelagem de perda de solo}

\subsubsection{Interpretação baseada unicamente em critérios de tolerância de perda de solo}

A aplicação da USLE permitiu estimar as taxas atuais de perda de solo no Ceveiro, sendo caracterizada a erosão na bacia. Para atender aos objetivos do planejamento, a etapa complementar vem a ser a interpretação dos resultados na forma de um estudo de impacto ou diagnóstico da erosão.

A maneira convencional de se interpretar os resultados, sugerida em Wischmeier \& Smith (1978), é a comparação das taxas atuais estimadas pelo modelo, com critérios de tolerância.

Pelo critério clássico de tolerância, e aceitando o valor médio de $12 \mathrm{Mg}$ $\mathrm{ha}^{-1} \mathrm{ano}^{-1}$ normalmente citado para representar a perda máxima tolerável para solos com gradiente textural (Lombardi Neto \& Bertoni, 1975), em cerca de 644 ha $(33,1$ $\%$ ), ocupados predominantemente com pastagens, reflorestamento e matas, as perdas estimadas foram inferiores ao valor referido como tolerável. Nos 1.301,52 ha restantes (66,9\%), ocupados com cana-de-açúcar e a pequena parcela de cultura anual, as perdas estimadas foram muito superiores a $12 \mathrm{Mg} \mathrm{ha}^{-1}$ ano $^{-1}$. A Figura 16 ilustra o mapa da bacia, interpretado segundo o critério clássico de tolerância, que o divide segundo duas possibilidades: áreas com perdas toleráveis, e áreas com perdas acima dos limites toleráveis. 


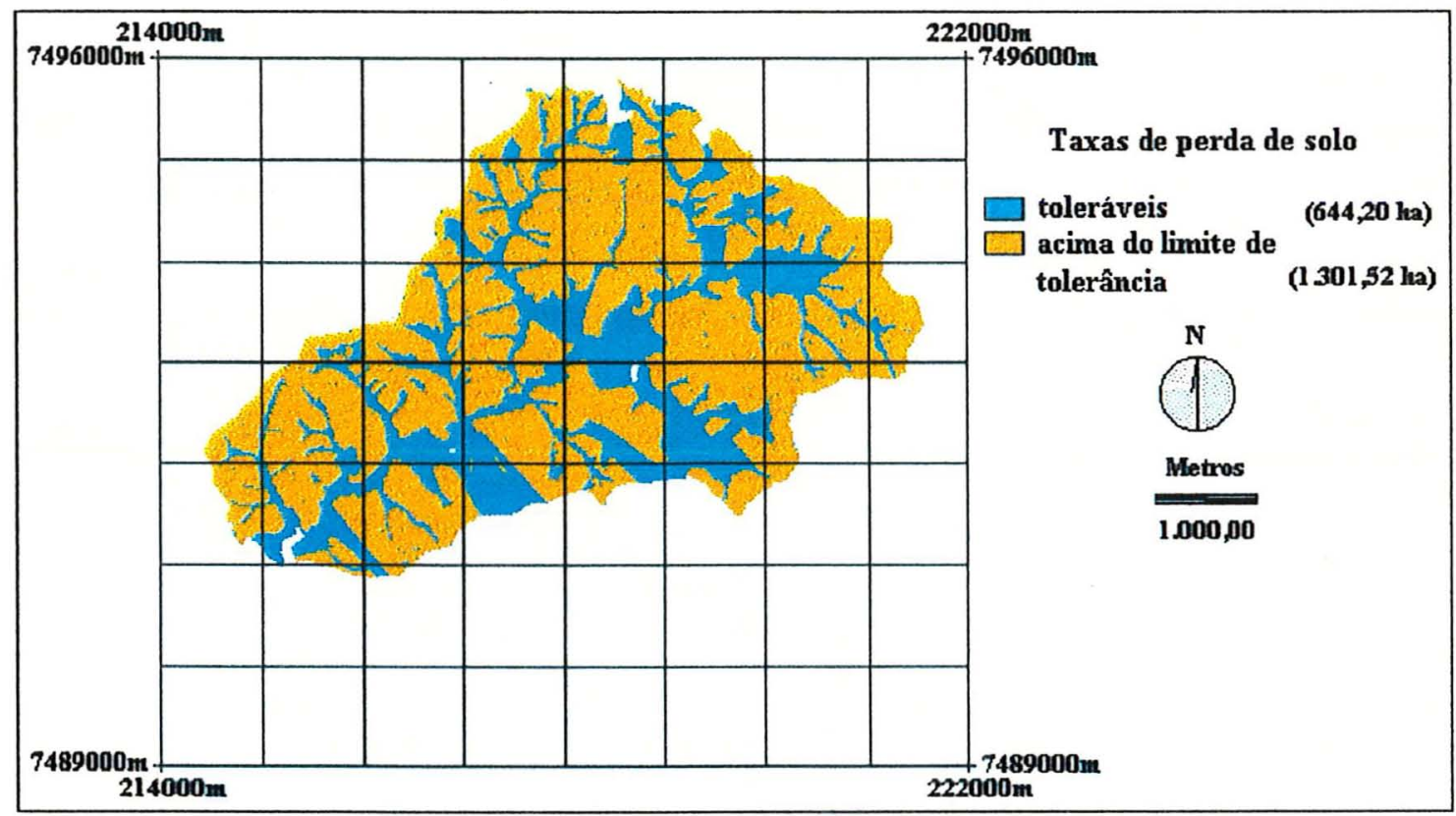

Figura 16- Interpretação das taxas de erosão pelo critério de tolerância de perda de solo

Com base nesse critério, pode ser afirmado que as terras presentemente se degradando na bacia, encontram-se preferencialmente ocupadas com a cultura da cana-de-açúcar. Neste caso, a recomendação do ponto-de-vista do planejamento conservacionista, seria a mudança da ocupação, para usos menos intensivos, ou alterações no manejo, para melhorar a proteção da superfície do solo, e permitir o ajuste das taxas atuais de erosão para níveis toleráveis. A esse respeito, pode-se ilustrar que a simples introdução de adubação verde com Crotalaria juncea L., nos meses de maior precipitação no verão, condicionaria uma queda no valor do fator $\mathrm{C}$ de 0,3066 para $0,2128^{2}$, uma diminuição bastante significativa, de cerca de $70 \%$, que reafirma a importância das decisões cerca do manejo, na extensão e grau da erosão observada.

Uma outra forma de aplicar o conceito de tolerância em planejamento, seria definir o uso permíssivel, tendo por base a perda tolerável. No estado de São Paulo, pode ser citado o trabalho de Donzeli et al. (1992), como um exemplo de aplicação. Nesse trabalho, os autores definiram unidades de capacidade de usomanejo permissível para a microbacia do córrego São Joaquim (município de Pirassununga), tendo por base o conceito de potencial natural de erosão (PNE =

\footnotetext{
${ }^{2}$ Comunicação pessoal da Dra. Isabella Clerici De Maria, pesquisadora do Centro de Solos e Recursos Ambientais do IAC.
} 
RKLS) e as perdas toleráveis por classe de solo, relacionando ainda com a capacidade de uso das terras.

Em um e outro caso, no entanto, a interpretação das taxas de erosão admite somente duas possibilidades, condição tolerável e condição não tolerável, o que não possibilita comparar alternativas de uso e manejo entre si, e nem extrair previsões.

No planejamento corretivo, visando a identificação de ajustes necessários em uma situação já instalada, ou quando o objetivo vem a ser a conversão em agricultura, para adoção de sistemas mais sustentáveis de produção, o apelo a limites de tolerância e à capacidade de uso das terras, pode ser insuficiente para estimular mudanças por parte do produtor, e para alertar os formadores de opinião e a população em geral, acerca dos riscos de degradação ambiental decorrente da erosão. Subsídios mais contundentes parecem necessários para estimular a tomada de decisões. No caso da bacia do Ceveiro, o fator que define a utilização preferencial da área com a cana-de-açúcar é econômico, e não um critério técnico. Possivelmente, a cultura deva continuar na bacia, enquanto o retorno econômico da atividade for positivo, à despeito da degradação das terras e da queda progressiva do seu potencial de produção, o que também nem sempre é facilmente perceptível, a não ser depois de transcorrido muito tempo.

$\mathrm{O}$ aspecto controverso da relação direta entre erosão e produtividade, por interferência do avanço tecnológico (Cassel \& Fryrear, 1990; Pierce \& Lal, 1994;), a dificuldade na definição de limites de tolerância de perda de solo (Pierce et al., 1984; Mc Cormick, Young \& Kimberlin, 1982), a constatação de que os níveis de tolerância atualmente aceitos, tendo em vista a atividade agrícola, são inadequados aos objetivos de conservação ambiental e de manutenção da qualidade multifuncional do solo (Mc Cormick, Young \& Kimberlin, op. cit.), e a crença de que argumentos mais contundentes são necessários para estimular a conversão em agricultura, conduziram a uma proposição não convencional para avaliação do impacto da erosão.

\subsubsection{Interpretação baseada na metodologia do índice de tempo de vida}

O método de avaliação que é ora proposto, foi desenvolvido tomando por base a interpretação da tolerância como uma função (Stamey \& Smith, 1964; 
Skidmore, 1982; Sparovek \& Van Lier, 1997), aliada ao conceito operacional de sustentabilidade (Hansen, 1996; Kruseman et al. 1996).

Trata-se de um índice quantitativo, com valor prognóstico, desenvolvido com base nas taxas estimadas de erosão, em uma taxa presumida de renovação do solo e na espessura de solo "disponível" para perda. Este índice, denominado Índice de Tempo de Vida, foi concebido como uma função da posição no terreno, e remete ao tempo para atingir uma condição de impacto não reversível prédefinida. A condição de impacto irreversível foi definida como sendo uma profundidade do solo, considerada crítica, abaixo da qual a qualidade multifuncional do solo e do ambiente é severamente degradada. A metodologia proposta permitiu caracterizar três situações distintas: 1) áreas em situação de conservação dos recursos, onde as taxas atuais de perda de solo $(p)$ são inferiores à taxa presumida de renovação do solo $(r)$, ou áreas onde $p<r ; 2)$ áreas com tempo de vida zero na condição presente, ou áreas onde a espessura do solum já está abaixo da profundidade crítica pré-definida, e nenhuma perda adicional é tolerável, recomendando-se intervenção para que $p$ de iguale a $r$;) áreas para controle e recomendação de intervenção segundo horizontes de planejamento selecionados, ou áreas que possuem um excedente de espessura do solum, além da profundidade crítica, e taxas de perda de solo superiores à taxa de renovação $(p>r)$. A metodologia foi aplicada à bacia do Ceveiro como um estudo de caso, inicialmente em separado para as categorias não cana-de-açúcar e cana-deaçúcar, sendo que os resultados foram posteriormente consolidados para a bacia do Ceveiro como um todo.

\subsubsection{Conservação e Tempo Zero nas áreas de não cana-de-açúcar (NC)}

Na maior parte da área de NC (626,08 ha), ou em cerca de 499,04 ha $(79,7 \%)$, a taxa presumida de formação do solo $\left(f=0,2 \mathrm{~mm} \mathrm{ano}^{-1}\right)$ é superior às taxas estimadas de perda de solo $(p)$. Estes resultados indicam que os solos nestes locais estão se espessando, e o uso atual das terra promove a conservação dos recursos de solo e água. Para os 127,04 ha restantes (20,29 \%), as taxas estimadas de perda de solo, ao contrário, superam a taxa presumida de renovação do solo, indicando que, neste caso, a qualidade do solo e do ambiente está se degradando. 
Nas áreas de NC onde a formação do solo supera as perdas por erosão (ou $f>p$ ), a profundidade média do solo, ponderada em relação à área de ocorrência, é de $72 \mathrm{~cm}$, variando entre um mínimo de $23 \mathrm{~cm}$ e um máximo de 172 $\mathrm{cm}(\mathrm{CV}=39,40 \%)$. Para o restante da área de $\mathrm{NC}$, onde as perdas de solo superam a formação ( $p>f$ em 127,04 ha), cerca de 100 ha são de solos mais profundos do que $50 \mathrm{~cm}$. Nos 27,08 ha restantes, os solos são mais rasos do que $50 \mathrm{~cm}$. Para a profundidade crítica de $50 \mathrm{~cm}$, significa que nas áreas de $\mathrm{NC}$, cerca de 27 ha $(4,33$ \%) experimentam uma situação de "impacto irreversível" já no tempo presente, o que configura tempo de vida zero. Isto é, o solo já está mais raso do que a profundidade mínima definida como crítica. Deve ser interpretado que qualquer perda adicional é intolerável, e a área deve ser considerada imprópria para qualquer uso, a não ser para manutenção da cobertura vegetal natural e para abrigo da vida silvestre.

Fazendo a análise para a profundidade crítica de $100 \mathrm{~cm}$, obteve-se para as áreas de NC do Ceveiro (626,08 ha), onde as perdas superam a formação $(127,04 \mathrm{ha})$, que em apenas 5,24 ha $(4,12 \%)$, os solos são mais profundos do que $100 \mathrm{~cm}$. Nos restantes 121,80 ha $(95,88 \%)$, os solos já são mais rasos do que 100 $\mathrm{cm}$, o que caracteriza, segundo os critérios adotados, impacto irreversível instalado no tempo presente, ou tempo de vida zero, observando-se as mesmas recomendações já indicadas.

\subsubsection{Conservação e Tempo Zero nas áreas ocupadas com cana-de-açúcar (C)}

De maneira inversa ao que foi relatado para a área de não cana-deaçúcar, quase a totalidade da área ocupada com cana-de-açúcar, mais especificamente em 99,42\% (1.312,04 ha), as taxas estimadas de perda de solo superam a taxa presumida de renovação do solo $(p>f)$. Este fato indica degradação generalizada da qualidade do solo e do ambiente na maior parte da microbacia.. Em apenas 7,6 ha $(0,58 \%$ da área com cana), a renovação do solo supera as perdas, o que caracteriza solo se espessando e área sendo conservada indefinidamente, na condição presente. Neste caso, a investigação dos fatores do modelo indicou que essas taxas muito pequenas de perda de solo se relacionam com valores muito 
baixos do fator LS, inferiores a 0,13 , indicando se tratarem de áreas planas ou praticamente planas.

A profundidade média dos solos nas áreas de cana-de-açúcar do Ceveiro, ponderada em relação à área de ocorrência, é de $78 \mathrm{~cm}$, variando entre um valor mínimo de $26 \mathrm{~cm}$ e um valor máximo de $184 \mathrm{~cm}$, com coeficiente de variação de $37 \%$. Nas áreas utilizadas com cana-de-açúcar, onde as perdas superam a formação $(p>f)$, cerca de 80,5\% (1.056,24 ha) são de solos com mais de $50 \mathrm{~cm}$. Nos $19,5 \%$ restantes da área de cana-de-açúcar (255,80 ha), solos mais rasos do que $50 \mathrm{~cm}$, configuram impacto irreversivel no tempo atual, ou tempo de vida zero pelos critérios já apresentados.

Para a profundidade crítica de $100 \mathrm{~cm}$, do total da área de $1.312,04$ ha, onde $p>f$, somente cerca de 338,20 ha (ou $25,8 \%$ ), são de solos com mais de $100 \mathrm{~cm}$. Para os 973,84 ha restantes, ou para $74,22 \%$ da área, solos mais rasos do que $100 \mathrm{~cm}$, caracterizam impacto irreversível no tempo atual (tempo de vida zero).

\subsubsection{Conservação e Tempo Zero na bacia do Ceveiro como um todo}

Para a bacia do Ceveiro, cerca de 506,64 ha (25,04 \%), são de terras onde a formação do solo supera as taxas estimadas de perda de solo por erosão, o que significa que o solo está se espessando, e a área se conservando indefinidamente. No Ceveiro, estas áreas estão predominantemente ocupadas com pastagens, reflorestamento e mata. No restante da área da bacia, os 1.439,08 ha $(73,96 \%)$ são de terras nas quais as perdas de solo por erosão superam a formação, e o solo está presentemente se degradando. Considerando a profundidade crítica de $50 \mathrm{~cm}$, cerca de 282,88 ha $(19,7 \%)$ são de terras, nas quais os solos são mais rasos do que $50 \mathrm{~cm}$, caracterizando impacto irreversível no tempo presente ou tempo de vida zero. Elevando-se a profundidade crítica para $100 \mathrm{~cm}$, a área da bacia onde já se configura a situação de degradação irreversível no tempo atual, salta para 1.095,54 ha, revelando uma situação extremamente grave do ponto-de-vista da conservação dos recursos de solo e água.

A Tabela 11 sumariza os resultados apresentados até o momento, e a Figura 17 ilustra a ilustra a interpretação da erosão na bacia através da metodologia proposta. Distingue-se na Figura 17, quatro situações: (1) $f>p$ (situação de 
conservação: solos se espessando no tempo presente); (2) $p>f$ e solos mais rasos do que a profundidade crítica $\left(\mathrm{P}_{\mathrm{c}}\right)$ de $100 \mathrm{~cm}$ (tempo zero para $\left.\mathrm{P}_{\mathrm{c}}=100 \mathrm{~cm}\right) ;(3) p>$ $f$ e solos mais rasos do que a profundidade crítica de $50 \mathrm{~cm}$ (tempo zero para $\mathrm{P}_{\mathrm{c}}=$ $50 \mathrm{~cm}$ ); (4) $p>f$ (situação para controle: solos com mais de $100 \mathrm{~cm}$, em degradação, no tempo presente). Como já comentado, as situações (2) e (3) já configuram impacto irreversivel, e qualquer perda adicional da espessura do solo, deve ser encarada como intolerável.

Tabela 11- Impacto da erosão do solo na bacia do Ceveiro: resumo da situação de conservação ou de degradação, nas áreas com cana-de-açúcar, nas áreas com usos menos intensivos e na bacia como um todo.

\begin{tabular}{|c|c|c|c|c|c|}
\hline \multirow[t]{2}{*}{ Local } & \multicolumn{5}{|c|}{$\begin{array}{c}\text { Área } \\
\text { ha }\end{array}$} \\
\hline & Total & $f>p$ & & $p>f$ & \\
\hline Cana & $1.319,63$ & 7,6 & $\begin{array}{c}\text { total } \\
1.312,04\end{array}$ & $\begin{array}{l}\text { solo }< \\
50 \mathrm{~cm} \\
255,80\end{array}$ & $\begin{array}{c}\text { solo < } \\
100 \mathrm{~cm} \\
973,84\end{array}$ \\
\hline Não cana & 626,08 & 499,04 & $-127,04$ & 27,08 & 121,80 \\
\hline Bacia & $1.945,72$ & 506,64 & $1.439,08$ & 282,88 & $1.095,64$ \\
\hline
\end{tabular}

Legenda: $f>p$, áreas onde a taxa de formação supera as taxas de perda de solo por erosão; $p>f$, áreas onde as taxas de perda de solo por erosão superam a taxa de formação; solo $<50 \mathrm{~cm}$, área onde os solos têm menos do que $50 \mathrm{~cm}$ de profundidade; solo $<100 \mathrm{~cm}$, área onde os solos têm menos do que $100 \mathrm{~cm}$ de profundidade.

\subsection{Tempo de vida nas áreas de controle da bacia do Ceveiro}

Caracterizadas as áreas na bacia onde as perdas estimadas superam a formação do solo, e os solos são mais profundos do que as profundidades críticas definidas para análise (de $50 \mathrm{~cm}$ e de $100 \mathrm{~cm}$ ), foi calculado o índice de tempo de vida, ou tempo para atingir a profundidade crítica (condição de degradação irreversível), tendo em conta as taxas atuais estimadas de perda de solo e a profundidade atual dos solos.

O Índice do Tempo de Vida foi aplicado nas áreas de controle das categorias cana-de-açúcar e não cana-de-açúcar, e na bacia como um todo, considerando os mesmos valores de profundidade crítica, de $50 \mathrm{~cm}$ e $100 \mathrm{~cm}$. Para cálculo do índice, as taxas estimadas de perda de solo foram subtraídas da taxa 
presumida de formação do solo $\left(0,2 \mathrm{~mm} \mathrm{ano}^{-1}\right)$, caracterizando a perda líquida de solo, conforme descrito anteriormente no Material e Métodos (Seção 3.8).

Foi obtido para as áreas com cana-de-açúcar do Ceveiro, que o tempo de vida médio, ponderado em relação à área, é de apenas 178 anos, para a profundidade crítica de $50 \mathrm{~cm}$. Isto é, em cerca de 178 anos, grande parte dos solos atualmente ocupados com cana-de-açúcar na bacia, terão sido degradados até a profundidade mínima de $50 \mathrm{~cm}$. Para a metade da área avaliada de 1.056 ha (ou para cerca de 533 ha), a situação é mais crítica, e o tempo de vida é igual ou inferior a 103 anos. Considerando a profundidade crítica de $100 \mathrm{~cm}$, a área avaliada cai para 338 ha, e o tempo de vida médio ponderado é de 102 anos. Na metade da área, ou em 172 ha, o tempo de vida é muito curto, igual ou inferior a 42 anos. Esses dados mostram que o uso com a cultura da cana-de-açúcar, da forma como vem sendo presentemente manejado na bacia, é uma alternativa que não se sustenta por mais 200 anos, na previsão mais otimista, ou não se manterá por mais. 50 anos, na projeção mais pessimista. Em ambos os casos o prognóstico é grave, requerendo intervenção imediata na área.

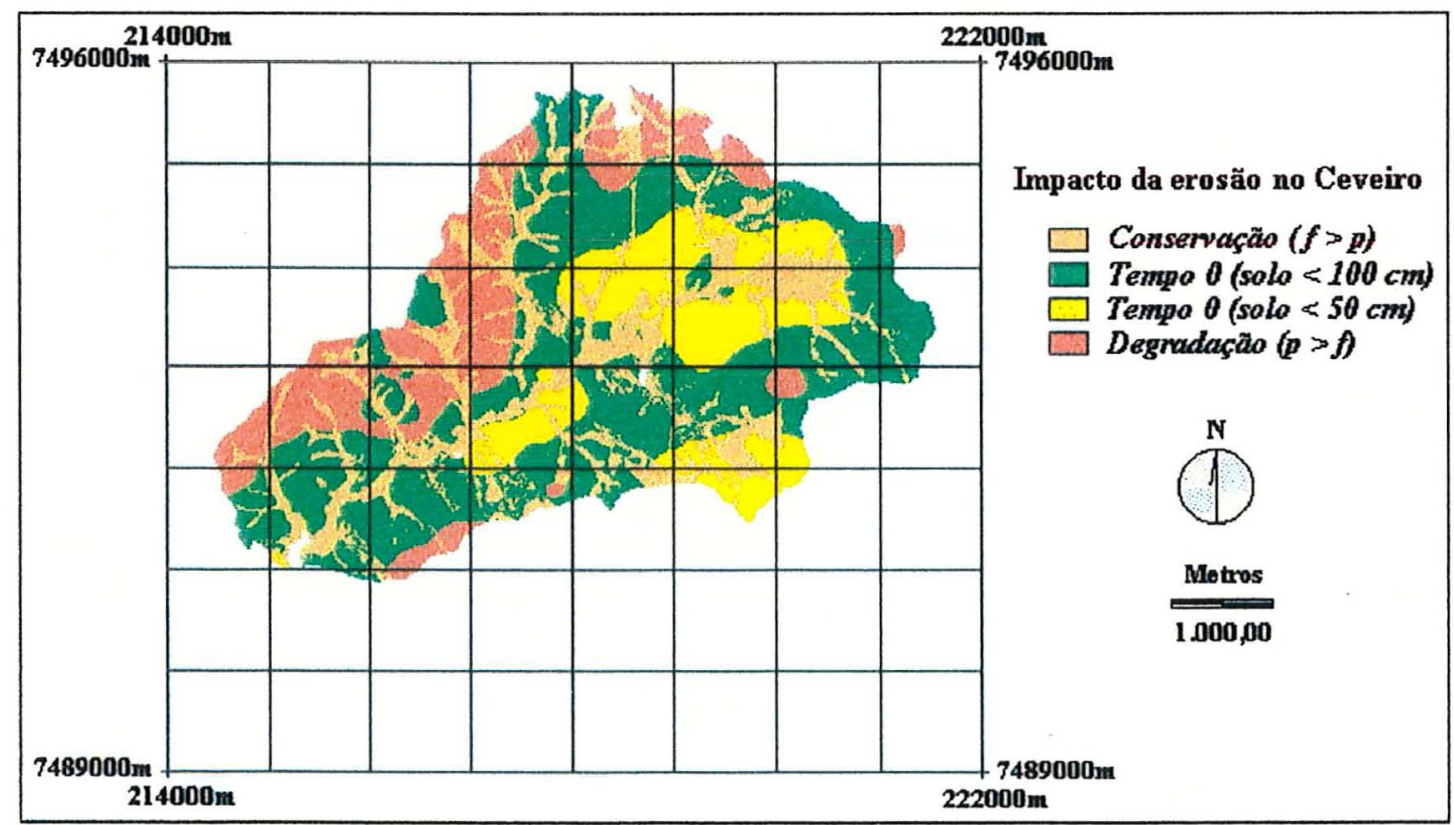

Figura 17- Panorama da erosão na bacia do Ceveiro: áreas em situação de conservação, de degradação, e sob impacto irreversível instalado, já no tempo atual (tempo zero).

Diferentemente, para as áreas de não cana-de-açúcar do Ceveiro, nos locais onde as perdas superam a formação, e os solos são mais profundos do que 50 
$\mathrm{cm}$ (eqüivalente a uma área de cerca de $100 \mathrm{ha}$ ), o tempo de vida médio ponderado é superior a 16.000 anos. Para metade da área (50 ha), o tempo de vida é inferior a 6.000 anos, mas em ambos os casos são tempos muito longos. Considerando a profundidade crítica de $100 \mathrm{~cm}$, o tempo de vida médio ponderado é de 29.000 anos. Entretanto, isto se refere a uma área avaliada de apenas 5,24 ha (onde $p>f$ e o solo $>100 \mathrm{~cm}$ ), o que significa menos de $0,3 \%$ da área total da bacia. Nestas áreas da bacia, onde predominam usos menos intensivos, com matas, reflorestamento e pastagens, e onde a erosão supera a formação, a situação pode ser considerada sustentável, uma vez que o tempo projetado para instalação de impacto irreversível, é bastante longo. Não se faz necessária qualquer intervenção conservacionista nestas áreas. Porém, caso ocorram desmatamentos, fogo, ou mudanças no uso e manejo destas áreas, o índice deverá ser reaplicado, e os resultados revistos.

Para a bacia do Ceveiro como um todo, a situação é intermediária aos dois extremos, caracterizados pelas áreas de cana-de-açúcar (solos se degradando rapidamente) e pelas áreas de não cana-de-açúcar (solos se degradando muito lentamente). Para a profundidade crítica de $50 \mathrm{~cm}$, o tempo de vida médio, ponderado pela área, é de 1.600 anos. Mas, para praticamente a metade da área avaliada de 1.156 ha (ou em $538 \mathrm{ha}$ ), o tempo de vida é inferior a 105 anos. Considerando a profundidade crítica de $100 \mathrm{~cm}$, a área avaliada (onde $p>f$ e o solo $>100 \mathrm{~cm}$ ) é de apenas 343 ha. Para esta porção da bacia, o tempo de vida médio ponderado é 551 anos, sendo que para $70 \%$ da área (240 ha), é inferior a 81 anos. Eliminando os cinco valores mais altos (tempo de vida $>65.000$ anos), que representam somente 0,2 ha, a média ponderada cai para 296 anos (contra os 551 anos) e o tempo de vida, para $50 \%$ da área, passa a ser inferior a 43 anos. Os dados mostram que a situação da bacia como um todo, é um reflexo um pouco melhorado do que ocorre nas áreas com cana-deaçúcar (o uso principal). Na projeção mais otimista, o uso econômico da área não se sustenta por mais 300 anos. A sustentabilidade do uso agrícola na bacia, é função da alteração do manejo da cultura da cana-de-açúcar, que corresponde ao uso impactante.

As Figuras 18 e 19 mostram a espacialização do tempo de vida para a bacia do Ceveiro, para as profundidades críticas de $50 \mathrm{~cm}$ e de $100 \mathrm{~cm}$, respectivamente. Foram incorporadas aos mapas as áreas de conservação e de tempo zero. Observe-se que mantidas as taxas atuais de perda de solo estimadas e o sistema 
presente de uso e manejo da área, em cerca de $88,7 \%$ da área presentemente se degradando (ou em $1.025 \mathrm{ha}$ ), os solos terão sido desgastados até $50 \mathrm{~cm}$, em até 200 anos (Figura 18). Para a profundidade de corte de $100 \mathrm{~cm}$, cerca de $79,2 \%$ da área sob degradação (272 ha), deverá atingir a profundidade crítica em até 100 anos (Figura 19).

Os resultados obtidos foram combinados de forma a se obter um diagnóstico integrado da situação de degradação na área da bacia. Foram construídos dois gráficos, representativos das situações relativas às profundidades críticas de 50 $\mathrm{cm}$ e de $100 \mathrm{~cm}$, respectivamente ilustrados nas Figuras 20 e 21 . Os gráficos mostram a área relativa (AR), ao uso considerado ou da bacia, e o tempo (em anos) para atingir a profundidade crítica considerada (que define a situação de degradação extrema).

$O$ gráfico deve ser interpretado da seguinte maneira:

1) o valor de $A R$ em que o gráfico corta o eixo $Y(X=0)$, denota a área relativa do uso em questão ou área relativa da bacia, para a qual o tempo de vida é nulo, ou seja, os solos já estão mais rasos do que a profundidade crítica pré-definida;

2) o patamar do gráfico, ou o valor da área relativa onde a curva se estabiliza, indica a máxima proporção da área, passivel de ser degradada até a situação extrema. Em outras palavras, se a curva se estabiliza ao redor de 0,5 , significa que no máximo $50 \%$ da área pode ser degradada até o extremo, sendo que para a outra metade, a condição atual é de conservação dos recursos (ou as taxas de formação superam as taxas de perda de solo);

3) abaixo do patamar, a inclinação da curva representa a taxa em que a área está sendo degradada, até chegar ao limite extremo, que será atingido, caso não se intervenha na área ou no uso em questão. A inclinação da curva, dada pela tangente no ponto, indica a intensidade do processo erosivo.

Com base nestas considerações, o gráfico da Figura 20 ilustra que para quase a totalidade das áreas de não cana-de-açúcar, a situação é de 


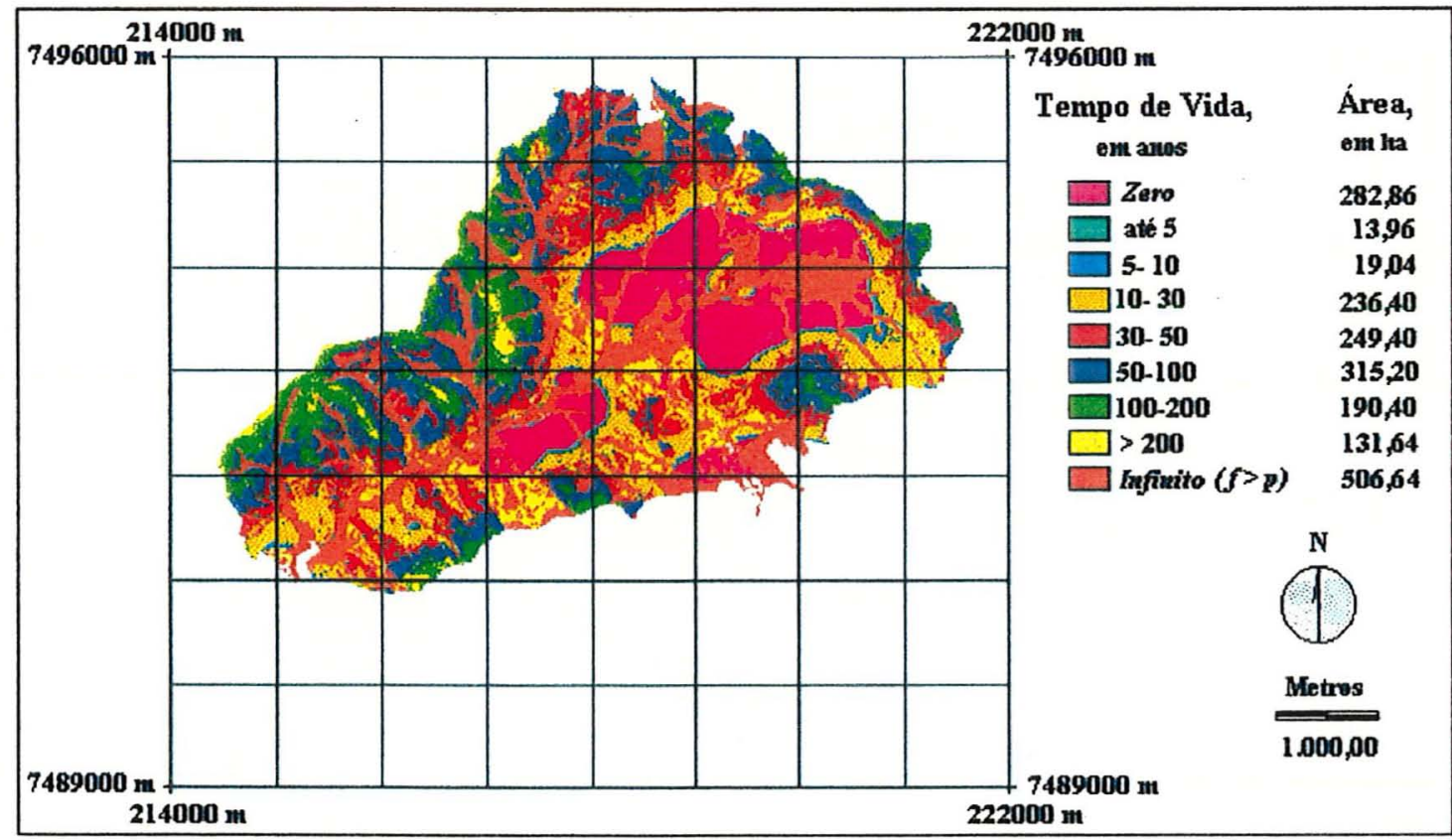

Figura 18- Mapa do Tempo de Vida da bacia do Ceveiro, considerando a profundidade crítica de $50 \mathrm{~cm}$.

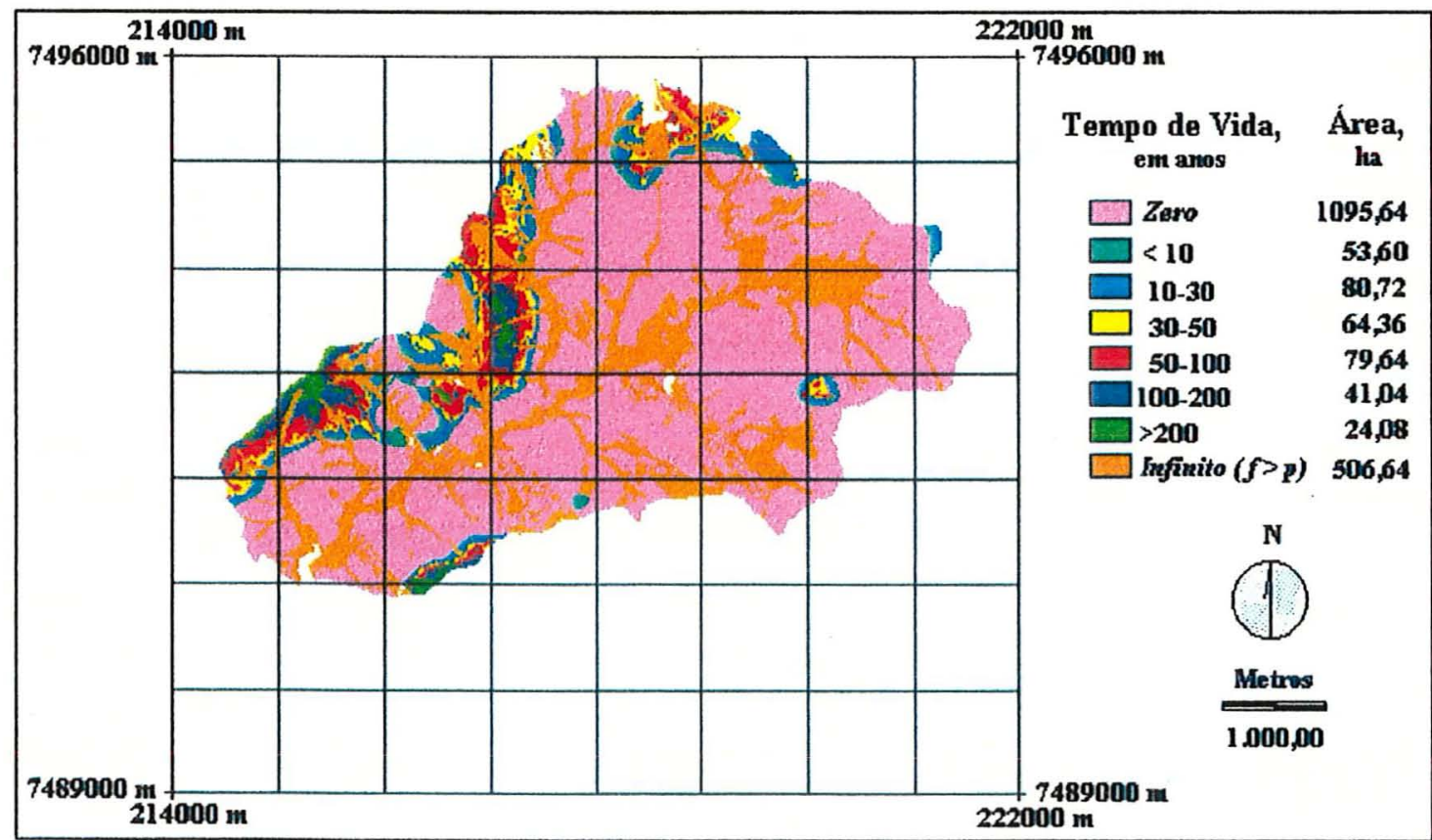

Figura 19- Mapa do Tempo de Vida da bacia do Ceveiro, considerando a profundidade crítica de $100 \mathrm{~cm}$. 


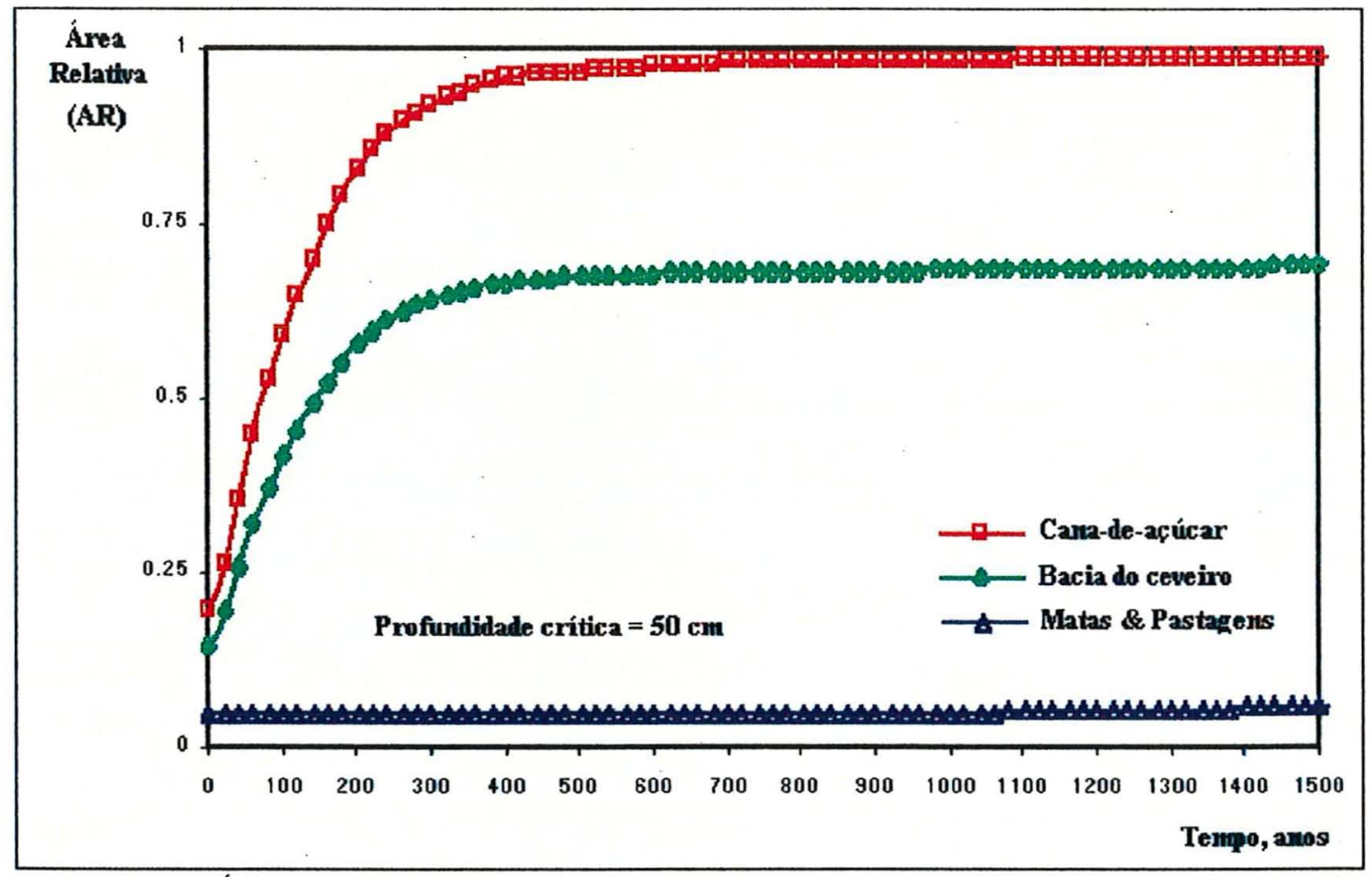

Figura 20- Índice do Tempo de Vida: nas áreas com cana-de-açúcar; nas áreas de não cana-de-açúcar; e, na bacia como um todo (profundidade crítica $=$ $50 \mathrm{~cm}$ )

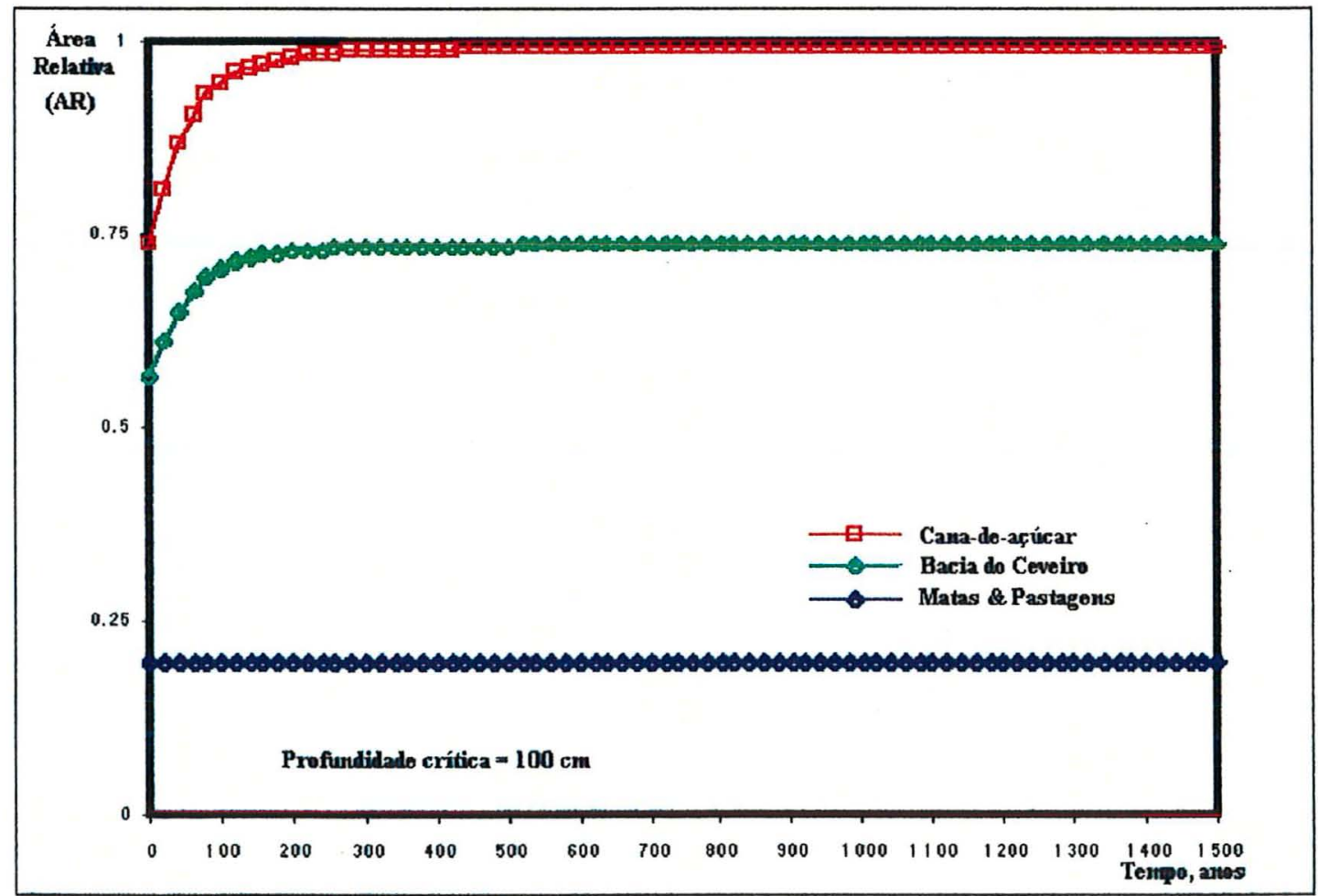

Figura 21- Índice de Tempo de Vida: nas áreas com cana-de-açúcar; nas áreas de não cana-de-açúcar reflorestamento); e, na bacia como um todo (profundidade crítica $=100 \mathrm{~cm}$ ) 
conservação dos recursos. Na pequena porção da área, onde as taxas de perda estimadas superam a taxa de formação presumida, a intensidade do processo é muito baixa (a inclinação da curva é praticamente zero), sendo que decorrerão milhares de anos, sem que ocorra alteração significativa da área relativa. Também é evidente que a proporção da área que configura impacto irreversível no tempo presente é muito pequena, inferior a $0,05(y=0,043$, em $x=0)$. Para a profundidade crítica de $100 \mathrm{~cm}$ (Figura 21), muda a proporção da área sob impacto irreversível no tempo atual, de $\mathrm{AR}=0,043$ para $\mathrm{AR}=0,1945$, indicando maior proporção da área sob tempo zero.

Para as áreas de cana-de-açúcar a condição é oposta. Apenas uma ínfima porção da área se encontra numa condição de conservação (indicada pela diferença entre $\mathrm{Y}=1$ e $\mathrm{Y}=$ patamar, que no caso é inferior a 0,01 ), significando que para mais de $99 \%$ da área, a degradação até a situação extrema é uma possibilidade concreta. No tempo presente, degradação extrema já se configura em $19 \%$ da área (ponto de interseção da curva com o eixo $\mathrm{y}$, em $\mathrm{x}=0$ ), porção onde os solos são mais rasos do que $50 \mathrm{~cm}$ (conforme Figura 20). Entre os dois extremos, a inclinação da curva do tempo de vida indica processo intenso de degradação, que pode determinar impacto irreversivel em quase $80 \%$ da área de cana, em menos de 200 anos. Para a profundidade crítica de $100 \mathrm{~cm}$ (Figura 21), a proporção da área de cana com tempo de vida igual a zero, aumenta de $\mathrm{AR}=0,1938$ para $\mathrm{AR}=0,7380$, o que era esperado uma vez que os solos na área são pouco profundos, e a profundidade média gira ao redor de $75 \mathrm{~cm}$.

Para a bacia como um todo, a análise do gráfico da Figura 20, mostra a ocorrência de degradação irreversível no tempo atual (solos $<50 \mathrm{~cm}$ ) em 14,54 \% da área (interseção da curva no eixo y em $\mathrm{AR}=0,1454$ ); a curva do tempo de vida se estabiliza ao redor de $\mathrm{AR}=0,74$, indicando que cerca de $26 \%$ da área da bacia experimentam uma condição de conservação dos recursos de solo e água, devida aos usos menos intensivos com mata, reflorestamento e pastagens. Entre os dois extremos, a inclinação da curva indica processo acelerado de degradação, mas menos intenso quando comparado ao que está ocorrendo nas áreas com cana-de-açúcar. $O$ prognóstico é de que $50 \%$ da área pode ser degradada ao extremo num intervalo de apenas 150 anos. Para a profundidade crítica de $100 \mathrm{~cm}$, o gráfico da Figura 21 mostra 
que para o Ceveiro, muda a proporção da área sob impacto irreversível no tempo presente, que salta da $\mathrm{AR}=0,1454$ para $\mathrm{AR}=0,5631$.

A análise do impacto da erosão acelerada na bacia do Ceveiro, sob o ponto-de-vista do índice de tempo de vida, mostrou que o estado de degradação na área é grave e o processo muito intenso. A qualidade do solo e a sustentabilidade da produção agrícola na área estão seriamente ameaçadas. A julgar pelos dados, em menos de 200 anos, será atingida a situação de degradação extrema para a maior parte da área. $\mathrm{O}$ índice de sustentabilidade proposto se mostrou adequado aos objetivos para os quais foi concebido, revelando-se uma ferramenta promissora ao planejamento do uso das terras em bases sustentáveis.

\subsection{Considerações finais}

A interpretação do impacto da erosão através do índice de tempo de vida, permitiu definir que em cerca de $26 \%$ da área da bacia, os solos estão presentemente se espessando, e a situação é de conservação de recursos. Em cerca de $15 \%$ da área, já se configura impacto irreversível instalado no tempo presente, para a profundidade crítica de $50 \mathrm{~cm}$, ou em $56 \%$ da área, para a profundidade crítica de 100 $\mathrm{cm}$. Nas demais áreas da bacia, mantido o sistema atual de manejo da cultura da canade-açúcar, a erosão acelerada deverá condicionar a exaustão da base do recurso solo, em cerca de $80 \%$ da área de cana-de-açúcar, em até 200 anos, considerando a profundidade crítica de $50 \mathrm{~cm}$.

A aplicação do Índice de Tempo de Vida é uma forma indireta de avaliar o impacto da erosão sobre a qualidade do solo e a sustentabilidade da produção agrícola de uma área. Traz como vantagens, não ser baseado nas relações diretas entre erosão e produção, um assunto controverso, e nem em valores correntes de tolerância, que são excessivos quando a finalidade além da produção agrícola, é também de conservar a qualidade dos recursos ambientais de modo geral.

É um critério compatível com a flexibilidade das questões do planejamento, podendo ser constantemente ajustado para acompanhar a evolução tecnológica e a dinâmica das alterações relativas ao uso e manejo das terras. A formulação do índice é adaptada ao seu desenvolvimento utilizando os recursos tecnológicos disponíveis como os sistemas de informação geográfica, os sistemas 
de posicionamento global, a análise com base em métodos geoestatísticos, entre outros.

$O$ índice desenvolvido pode ser aplicado a tipos específicos de uso da terra ou à bacia como um todo. Da forma como foi definido, atende ao requisito de especificidade, uma vez que seu valor é uma função da posição no terreno, e leva em conta a variabilidade intrínseca do ambiente. Sua aplicação permite o estabelecimento de comparações objetivas entre alternativas de uso, pois o índice é quantitativo, isto é, é um parâmetro contínuo, em oposição ao caráter discreto da interpretação baseada na tolerância, que somente admite duas possibilidades: perda tolerável e perda não tolerável. Além disso, o índice proposto é dotado de valor prognóstico, o que permite o estabelecimento de projeções e a avaliação de cenários econômicos. Finalmente, o critério proposto é um parâmetro singular e integrado da resposta do sistema, o que lhe confere uma característica diagnóstica. A caracterização do índice, considerando todos esses aspectos, revela-o um critério operacional na avaliação do impacto da erosão acelerada, na sustentabilidade da produção agrícola. Os resultados obtidos municiam o planejador com dados, que lhe permitem $o$ ajuste das ações a horizontes de planejamento pré-definidos, de acordo com o plano de desenvolvimento.

$\mathrm{O}$ indice de tempo de vida instrumentaliza a análise das conseqüências das ações efetuadas no presente, sobre a economia dos recursos e a qualidade do ambiente no futuro. A possibilidade de projeção de instalação de impactos irreversíveis, pode sensibilizar o poder público, os produtores e a população em geral, para a necessidade da adoção efetiva de um modelo sustentável de desenvolvimento, em que todos os agentes sociais, conscientizados acerca dos problemas, comprometam-se efetivamente com as suas soluções.

O critério atual de avaliação da atividade agrícola, baseado sobretudo na lucratividade imediata (sustentabilidade econômica no curto prazo), deve ser considerado inadequado. Os resultados mostram que a situação encontrada hoje na bacia, muito provavelmente mantida por critérios econômicos, é conflitante com os fundamentos da atividade de planejamento, que se assenta sobre objetivos de desenvolvimento sustentável e de conservação e melhoria dos recursos naturais para as gerações futuras. Pronta intervenção na área, visando ao ajuste da cultura da cana-deaçúcar, é fortemente recomendada. 


\section{CONCLUSÕES}

1. $\mathrm{O}$ ajuste criterioso dos fatores da USLE às condições locais da bacia do Ceveiro, seguido da aplicação do modelo para estimativa das taxas atuais de perda de solo, permitiu caracterizar com sucesso a erosão instalada na bacia;

2. A modelagem da erosão na bacia revelou que, para uma mesma condição climática (fator $\mathrm{R}$ constante), o fator $\mathrm{C}$, relativo ao uso e manejo das terras, foi o que definiu a ordem de grandeza das perdas estimadas pela USLE;

3. Para uma mesma categoria de uso (fator $\mathrm{C}$ constante), o fator que mais influenciou a variação observada nas taxas estimadas de erosão, foi o fator LS ou topográfico. Para todas as categorias de uso, o aumento do fator LS se relacionou diretamente com o aumento das taxas estimadas de erosão;

4. A influência da erodibilidade do solo, ou fator $K$, na variação das taxas estimadas de erosão foi inconclusiva. Para todas as categorias de uso, a dispersão randômica dos dados, não permitiu definir um padrão ou uma tendência consistente para explicar a variação observada;

5. As terras ocupadas com culturas, encontram-se em processo intenso de degradação da qualidade de seus recursos naturais, em especial dos solos, em oposição ao que ocorre nas terras ocupadas com mata, reflorestamento e pastagens, onde o processo erosivo é pouco intenso. Ficou demonstrado que a cultura da cana-de-açúcar é o uso impactante da bacia;

6. A interpretação dos resultados baseada exclusivamente em limites de tolerância, não permitiu comparações entre categorias nem o estabelecimento de previsões; 
7. A interpretação através do índice de tempo de vida, revelou-o uma ferramenta quantitativa de avaliação do impacto da erosão instalada e de previsão da instalação de novos impactos. A aplicação do índice permitiu diferenciar entre: a) áreas em estado de conservação; b) áreas sob impacto irreversível já no tempo atual; c) áreas para controle, com indicação do tempo remanescente para instalação da situação de máxima degradação (interpretação com valor prognóstico);

8. O desenvolvimento do índice e sua aplicação em um estudo de caso, permitiu comprovar a hipótese inicial de trabalho, de que interpretar a erosão instalada, com base apenas na tolerância de perda de solo, não é suficiente para municiar o planejador com os dados de que ele necessita para a execução do planejamento em bases sustentáveis. 


\section{REFERÊNCIAS BIBLIOGRÁFICAS}

ALEXANDER, E.B. Rates of soil formation: implications for soil-loss tolerance. Soil Science, v.145, n.1, p.37-45, Jan. 1988.

BARTHELMESS, H. A zona de Piracicaba. Curitiba, 1958. 142p. Tese (Livre Docência) - Faculdade de Filosofia, Ciências e Letras, Universidade do Paraná.

BEEK, K.J. Land evaluation for agricultural development: some explorations of land-use systems analysis with particular reference to Latin America. Wageningen, 1978. 333p. Thesis (Ph. D) - University of Agriculture.

BENNET, H. H.; LOUDERMILK, W. C. General aspects of the soil-erosion problem. In: Soils and Men. Washington, DC: USDA, Yearbook of Agriculture, p.581-608. 1938.

BERTONI, J.; LOMBARDI NETO, F. Conservação do solo. São Paulo: Ícone, 1990. (Coleção Brasil Agrícola)

BLUM, W. E. H. Basic concepts: degradation, resilience, and rehabilitation. In: LAL, R. ; BLUM, W. E. H.; VALENTIN, C.; STEWART, B. A. Methods of assessment of soil degradation. Boca Raton: CRC Press, 1997. p. 1-16.

BOUMA, J. Using soil survey data for quantitative land evaluation. Advances in Soil Science , v.9, p.177-213, 1989.

BURING, P. Availability of agricultural land for crop and livestock production. In: PIMENTEL, D.; HALL, C. W. (Ed.). Food and natural resources. San Diego: Academic Press, 1989. p.77-85.

BURROUGH, P.A. Principles of geografical information systems for land resources assessment. Oxford: Oxford University Press, 1986. 194p. (Monographs on Soil and Resources Survey, 12)

BURROUGH, P.A. Mapping and map analysis: new tools for land evaluation. Soil, Use and Management, v.3, n.1, p.20-25, Mar. 1987. 
BURROUGH, P.A. Matching spatial databases and quantitative models in land resource assessment. Soil, Use and Management, v.5, n.1, p.3-8, Mar. 1989.

CASSEL, D. K. FRYREAR, D. W. Evaluation of productivity changes due to accelerated soil erosion. In: LARSON, W. E.; FOSTER, G. R.; ALLMARAS, R. R.; SMITH, C. M. Proceedings of soil erosion and productivity workshop. Saint Paul: University of Minesota, 1990. p. 41-54. Cap. 3.

CLARK II E.H.; HAVERKAMP J.A.; CHAPMAN W. Eroding soils: (the off-farm impacts). Washington: The Conservation Foundation, 1985. 252 p.

COCKS, K.D. What on earth is environmental planning? In: BASINSKI, J.J.; COCKS, K.D. (Ed.) Environmental planning and management. Camberra: Commonwealth Science Council; CSIRO Division of Water and Land Resources, 1985. p.20-30.

COX, G. W. The linkage of inputs to outputs in agroecosystems. In: LOWRANCE, R.; STINNER, B. R.; HOUSE, G. J. (Ed.). Agricultural ecosystems. New York: John Wiley, 1984. p. 187-208.

DAVIS, J. R. Techniques in planning. In: BASINSKI, J.J.; COCKS, K.D. (Ed.) Environmental planning and management. Camberra: Commonwealth Science Council; CSIRO Division of Water and Land Resources, 1985. p. 37-58.

DENARDIN, J.E. Erodibilidade do solo estimada por meio de parâmetros físicos e químicos. Piracicaba, 1990. 114 p. Tese (Doutorado) - Escola Superior de Agricultura "Luiz de Queiroz", Universidade de São Paulo.

DONZELI, P. L.; VALÉRIO FILHO, M.; PINTO, S. dos A F.; NOGUEIRA, F. de P.; ROTTA, C. L.; LOMBARDI NETO, F. Técnicas de sensoriamento remoto aplicadas ao diagnóstico básico para planejamento e monitoramento de bacias hidrográficas. In: LOMBARDI NETO, F.; CAMARGO, O. A. de (Coord.). Microbacia do Córrego São Joaquim (Município de Pirassununga, SP). Campinas: Instituto Agronômico, 1992. P.91- 119 (IAC Documentos, 29)

DORAN, J.W.; SARRANTONIO, M.; LIEBIG, M.A. Soil health and sustainability. Advances in Agronomy, v. 56. p.1-54, 1996.

DREGNE, H. E. Historical perspective of accelerated erosion and effect on world civilization. ASAE, 1982. p.1-14. (ASAE. Special Publication, 45).

EASTMAN, J. R. IDRISI - user's guide. Worcester: Clark University. 1992.

EL-SWAIFE, S. A.; DANGLER, E. W. Rainfall erosion in the tropics: a state-of-the-art. In: KUSSOW, W.; EL-SWAIFY, S. A.; MANNERING, J. (Ed.) Soil erosion and 
conservation in the tropics. Madison: American Society of Agronomy, 1982. p.125 .

EMPRESA BRASILEIRA DE PESQUISA AGROPECUÁRIA. Serviço Nacional de Levantamento e Conservação de Solo. Critérios para distinção de classes de solos e de fases de unidades de mapeamento; normas em uso pelo SNLCS. Rio de Janeiro, 1988. 67p.(SNLCS. Documentos, 11).

FAO. Approaches to land classification. Rome, 1974. 120 p. (FAO. Soils Bulletin, 22)

FAO. A Framework for land evaluation. Rome, 1976. 72 p. (FAO. Soils Bulletin, 32).

FIGUEIREDO, A. G. Análise de produção e transporte de sedimentos nas Bacias do Rio do Peixe e Rio Aguapeí. São José dos Campos, 1988. Dissertação (M.S.) - Instituto Nacional de Pesquisas Espaciais.

FIORIO, P. R. Avaliação Cronológica do Uso da Terra e seu Impacto no Ambiente da Microbacia Hidrográfica do Córrego do Ceveiro da Região de Piracicaba, SP. Piracicaba, 1998. 114 p. Dissertação (Mestrado) - Escola Superior de Agricultura 'Luiz de Queiroz", Universidade de São Paulo.

FRIEND, J.A. Achieving soil sustainabitity. Journal of Soil and Water Conservation, v.47, n.2, p.156-157, Mar./ Apr. 1992.

GRAAF, J. DE. The price of soil erosion: (An economic evaluation of soil conservation and watershed development). Netherlands Foundation for the Advancement of Tropical Research (WOTRO), Wageningen: Netherlands Organization for Scientific Research, 1996. (Project, W 45-104). p. 1-25.

HAMLET, J. M.; MLLER, D. A.; DAY, R. L.; PETERSON, G. W.; BAUMER, G. M.; RUSSO, J. Statewide GIS-based ranking of watersheds for agricultural pollution prevention. Journal of Soil and Water Conservation, v.47, n.5, p.399-404, Sept./Oct. 1992.

HANSEN, J.W. Is agricultural sustainability a useful concept? Agricultural Systems, v. 50, p.117-143, 1996.

HESSION, W. C.; SHANHOLTZ, V. O. A geographic information system for targeting nonpoint-source agricultural pollution. Journal of Soil and Water Conservation, v.43, n.3., p.264-266, May/June 1988.

HOLÝ, M. Erosion and environment. Exeter: Pergamon Press, 1980. 225 p. (Environmental Sciences and Applications, 9). 
HUDSON, N. W. Soil conservation. Ithaca: Cornell University Press, 1973. 320 p.

INSTITUTO AGRONÔMICO. Carta semi-detalhada do Estado de São Paulo: Quadrícula de Piracicaba. Campinas, 1989. Escala 1. 100.000.

INSTITUTO DE PESQUISAS TECNOLÓGICAS. Mapa geológico do Estado de São Paulo. Escala 1:500.000. São Paulo, 1981.2v. esc. 1: 500.000 (Monografias, 6).

JÄGER, S. Modelling regional soil erosion susceptibility using the Universal Soil Loss Equation and GIS. In: RICKSON, R. J. (Ed.) Conserving soil resurces: (European perspectives). Cambridge: Cranfield University, Silsoe College. Cap. 17: p.161-177, 1994.

JENNY, H. The soil resource: origin and behavior. New York: Spring-Verlag, 1980. (Ecological Studies, 37).

KIEHL, E.J. Manual de edafologia: relações solo-planta. São Paulo: CERES, 1979. 262p.

KRAMER, P.J.; BOYER, J. S. Water relations of plants and soils. San Diego: Academic Press, 1995. p. 16-41. 495 p.

KRUSEMAN, G.; RUBEN, R.; KUYVENHOVEN, A.; HENGSDIJK, H.; van KEULEN, $H$. Analytical framework for disentangling the concept of sustainable land use. Agricultural Systems, v. 50, p. 191-207, 1996.

KUTÍLEK, M.; NIELSEN, D. R. Soil Hidrology. Cremlingen: CATENA-VERLAG, 1994. p. 16-27: Soil Porous System.

LAFLEN, J. M.; ROOSE, E. J. Methodologies for assessment of soil degradation due to water. In: LAL, R. ; BLUM, W. E. H.; VALENTIN, C.; STEWART, B. A. Methods of assessment of soil degradation. Boca Raton: CRC Press, 1997. p.3155.

LAL, R.; STEWART, B. A. Soil degradation: a global threat. Advances in Soil Science, v. 11, p. xiï-xvii, 1990 a.

LAL, R. Soil erosion and land degradation: the global risks. Advances in Soil Science, v. 11 , p. $129-172.1990$ b.

LAL, R. Soil erosion by wind and water: problems and prospects. In: LAL, R. (Ed.) Soil Erosion Research Methods. Delray Beach: St.Lucie Press, Soil and Water Conservation Society, 1994. p.1-9. 
LAL, R. Soil quality and sustainability. In: LAL, R. ; BLUM, W. E. H.; VALENTIN, C.; STEWART, B. A. Methods of assessment of soil degradation. Boca Raton: CRC Press, 1997. p.17-30.

LAL, R.; STEWART, B. A. Need for land restorarion. Advances in Soil Science, v. 17, p. 1-11. 1992.

LIBARDI, P. L.; PREVEDEllO, C. L.; PAUleTtO, E. A.; MORAES, S. O. Variabilidade espacial da umidade, textura e densidade de partículas ao longo de uma transeção. R. bras. Ci. Solo, v. 10: 85-90, 1986.

LOMBARDI NETO, F.; MOLDENHAUER, W. C. Erosividade da chuva: sua distribuição e relação com perdas de solo em Campinas, SP. In: Encontro Nacional de Pesquisa sobre Conservação do Solo, 3. Recife, 1980. Anais.

LOMBARDI NETO, F.; BERTONI, J. Erodibilidade de solos paulistas. Campinas: Instituto Agronômico, 1975. 12 p. (IAC. Boletim Técnico, 27)

LYNAM, J. K.; HERDT, R. W. Sense and sustainability as an objective in international agricultural research. Agricultural Economics, v. 3, n. 4, p. 381-397, Dec. 1989.

MABBUTT, J. A. Review of concepts of land classification. In: STEWART, G. A. (Ed.) Land Evaluation: Papers of a CSIRO Symposium. Vitoria: Mascmillan of Australia, 1968. p. 11-27.

MADIGAN, E. Introduction. In: Agriculture and environment: Washington: Government Printing Office, 1991. Yearbook of Agriculture.

MARQUES, J. J. G. S. M.; CURI, N.; FERREIRA, M. M.; LIMA, J. M.; SILVA, M. L. N.; CAROLINO de SÁ, M. A. Adequação de métodos indiretos para estimativa da erodibilidade de solos com horizonte B textural no Brasil. R. bras. Ci. Solo, v. 21, $n$. 3, p. 447-456, 1997.

Mc COOL, D. K.; RENARD, K. G. Water erosion and water quality. Advances in Soil Science, v.13, p.175-185, 1990.

Mc CORMACK, D. E ; YOUNG, K. K. KIMBERLIN, L.W. Current criteria for determining soil loss tolerance. ASAE, 1982. (ASAE. Special Publication, 45). Cap.9.

MELLEROWICZ, K.T.; REES, H.W.; CHOW, T. L.; GHANEM, I. Soil conservation planning at watershed level using the Universal Soil Loss Equation with GIS and microcomputer technologies: a case study. Journal of Soil and Water Conservation, v.40, n.4, p. 332-335. Mar./Apr. 1994. 
MUTCHLER, C. K.;MURPHREE, C.E.; MCGREGOR, K. C. Laboratory and field plots for erosion research. In: LAL, R. (Ed.) Soil erosion research methods. 2 ed. Delray Beach: St.Lucie Press, Soil and Water Conservation Society, 1994. p.1-9.

OLDEMAN, L. R.; HAKKELING, R. T. A.; SOMBROEK, W.G. World map of the status of human-induced soil degradation. Nairobi/Wageningen: UNEP/ ISRIC,1991. (GLASOD Project)

PARK, J.; SEATON, R. A. F. Integrative research and sustainable agriculture. Agricultural Systems, v. 50, p. 81-100, 1996.

PIERCE, F. J.; LAL, R. Monitoring the impact of soil erosion on crop productivity. In: LAL, R. (Ed.) Soil erosion research methods. 2. ed. Delray Beach: St. Lucie Press, Soil and Water Conservation Service, 1994. Cap. 10, p. 235-263.

PIERCE, F. J.; LARSON, W. E.; DOWDY, R. H. Soil loss tolerance: maintenance of long-term soil productivity. Journal of Soil and Water Conservation, v. 39, n. 2, p.136-138. Mar./ Apr. 1984.

PIMENTEL, D.; TERHUNE, E. C.; DYSON-HUDSON, R.; ROCHEREAU, S.; SAMIS, R.; SMITH, E. A.; DENMAN, D.; REIFSCHNEIDER, D.; SHEPARD, M. Land degradation: effects on food and energy resources. Science, v. 194, p.149-155. Oct. 1976.

PINTO, S. A. F. Sensoriamento remoto e integração de dados aplicados no estudo da erosão dos solos: contribuição metodológica. São José dos Campos, 1991. Tese (Doutorado) - Instituto Nacional de Pesquisas Espaciais.

RAIJ, B. van; QUAGGIO, J. A., CANTARELlA, H.; FERREIRA, M. E.; LOPES, A. S.; BATAGLIA, O. C. Análise química de solos para fins de fertilidade. Campinas: Fundação Cargill, 1987. 170 p.

RANIERI, S. B. L. Avaliação de métodos e escalas de trabalho para determinação de risco de erosão em bacia hidrográfica utilizando SIG. São Carlos, 1996. Dissertação (M.S.) - Escola de Engenharia de São Carlos, Universidade de São Paulo.

ROCHA, J. V.; LOMBARDI NETO, F. ; BACELlAR, A. A. A. Cálculo do fator comprimento de rampa (L): uma metodologia para uso em Sistema de Informação Geográfica. In: SIMPÓSIO NACIONAL DE CONTROLE DE EROSÃO. Bauru, 1995. Resumos. p. 421-422.

SALVIANO, A. A. A.; VIEIRA, S. R ; SPAROVEK, G. Variabilidade de atributos de solo e de Crotalaria juncea L. em área severamente erodida. R. Bras. Ci. Solo, v. 22, n.1, p. 115-122, 1998. 
SCHALLER, N. Low-Input Sustainable Agriculture. In: Estados Unidos. Department of Agriculture. Yearbook of Agriculture. Agriculture and Environment. Washington: Government Printing Office, 1989. p. 216-219.

SCHERTZ, D. L. The basis for soil loss tolerances. Journal of. Soil and Water Conservation, v.38, n.1, p.10-14. Jan./Feb. 1983.

SCHMIDT, B. L.; ALLMARAS, R. R.; MANNERING, J. V.; PAPENDICK, R. I. Determinants of Soil Loss Tolerance (Preface). In: AMERICAN SOCIETY OF AGRONOMY. Determinants of soil-loss tolerance. 1982. p.vii-ix.

SILVA, J. R.; FREIRE, O. Previsão de perdas de solo e estimativa de assoreamento em relação a características de uma bacia hidrográfica. Ciência Agronômica, v.17, n.1, p. 13-27. Jun. 1986

SKIDMORE, E. L. Soil-loss tolerance. In: AMERICAN SOCIETY OF AGRONOMY. Determinants of soil-loss tolerance. 1982. p.87-93,

SOIL AND WATER CONSERVATION SERVICE. Sustainable agriculture. Journal of Soil and Water Conservation, v. 50, n. 6, p. 634-635, Nov./ Dec., 1995.

SPAROVEK, G. (Coord.) Plano Diretor da Microbacia do Córrego do Ceveiro. v. 1: Diagnóstico da situação, levantamento de problemas e propostas de solução. Piracicaba: ESALQ, 1991.286 p.

SPAROVEK, G.; JONG van LIER, Q. Definition of tolerable soil erosion values. Rev. bras. C. Solo, v. 21, p. 467-471, jul./ set. 1997.

SPAROVEK, G; LEPSCH, I.F. Diagnóstico de uso e aptidão das terras agrícolas de Piracicaba. In TAUK-TORNISIETO, S. M.; GOBBI, N.; FORESTI, C.; LIMA, S. T. Análise ambiental: estratégias e ações. São Paulo: Queiroz, 1995. p. 273-9.

SPAROVEK, G.; TERAMOTO, E. R.; TORETA, D. M.; ROCHELE, T. C. P.; SHAYER,E. P. M. Erosão simulada e a produtividade da cultura de milho. Rev. bras. C. Solo, v. 15, n. 3, p. 363-368, set./ dez. 1991.

SPAROVEK, G.; WEILL, M. A. M; RANIERI, S. B. L.; SCHNUG, E.; SILVA, E. F. The time-life concept as a tool for erosion tolerance definiton. Scientia Agricola, v. 54, n. esp., p.130-135, jun. 1997.

STAMEY, W. L.; SMITH, R. M. A conservation definition of soil tolerance. Soil Science, v.97, p.183-186, 1964.

STATISTICAL ANALYSIS SYSTEM INSTITUTE. SAS/ STAT procedure guide for personal computers, v.5. Cary: SAS Institute, 1991. 
STINNER, B. R.; HOUSE, G. J. The search for sustainable agroecosystems. Journal of Soil and Water Conservation, v. 44, n. 2, p. 111-116. Mar./ Apr. 1989.

THORNTHWAITE, C.W.; MATHER, J. R. The water balance. Centerton: Drexed Institute of Technology, 1955. 4p. (Publication in Climatology, v.8, n.1)

VIEIRA, S. R. Variabilidade espacial de argila, silte e atributos químicos em uma parcela experimental de um latossolo roxo de Campinas (SP). Bragantia, v.56, n.1, p. 181190,1997

VIEIRA S. R.; LOMBARDI NETO, F.; BURROWS, I. T. Mapeamento das chuvas máximas prováveis para o Estado de São Paulo. Rev. bras. Ci. Solo, v. 15, p. 219$224,1991$.

VIEIRA, S. R.; NIELSEN, D. R.; BIGGAR, J. W. Spatial variability of field-measured infiltration rate. Soil Sci. Soc. Am. J., v. 45, p.1040-1048, 1981.

VIEIRA, S. R.; HATFIELD, J. L.; NIELSEN, D. R.; BIGGAR, J. W. Geostatistical theory and application to variability of some agronomical properties. Hilgardia, v.51, p. 1-75, 1983.

VIEIRA, S. R.; TILLONTSON, P. M.; BIGGAR, J. M.; NIELSEN, D. R. Scaling of semivariograms and the kriging estimation of field-measured properties. Rev. bras. Ci. Solo, v. 21, n. 4, p.525-533, out./ dez. 1997.

WISCHMEIER, W.H., SMITH, D.D. Predicting rainfall erosion losses: a guide to conservation planning. Washington: USDA, 1978. 57 p. (USDA. Agricultural Handbook, 537).

WISCHMEIER, W.H., SMITH, D.D. Predicting rainfall erosion losses from cropland east of the Rocky Mountains. Washington, USDA, Agricultural Research Service, 1965. 47 p. (USDA. Agricultural Handbook, 282)

YOUNG, A. Tropical soils and soil survey. Cambridge, University Press., 1976. 423p. 